

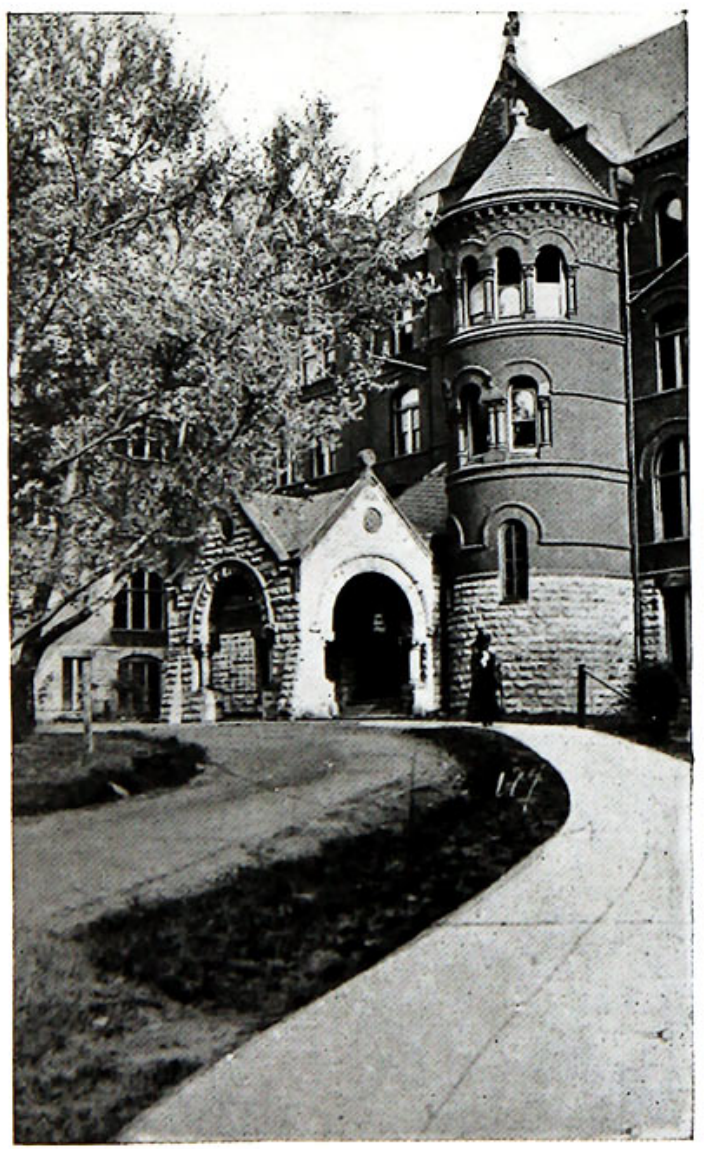

ENTRANCE TO MAIN BUILDING 


\section{Macalester College Bulletin}

\section{CATALOG NUMBER}

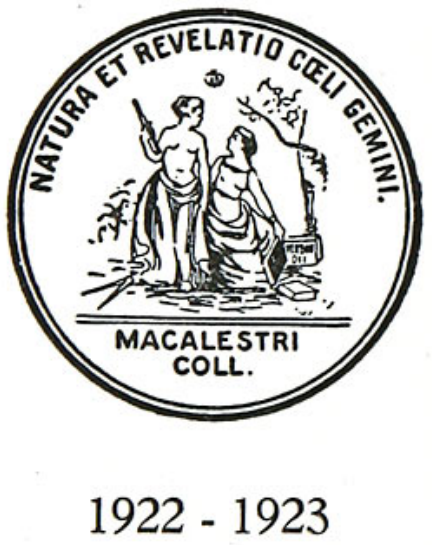

Accredited by the North Central Association of Colleges and Secondary Schools.

Macalester College uses in its official publications a number of the reformed spellings recommended by the Simplified Spelling

Board and now authorized by standard dictionariea

\section{SAINT PAUL, MINNESOTA}

Entered April 29, 1905, at Saint Paul, Minn., as second class matter under Act of Congress, July 16, 1894.

Acceptance for mailing at special rate of postage provided for in Section 1103, Act of October

3,1917 , authorized July 31 .

1918.

Issued Ouarterly in October, January, A pril and June. 


\section{College Galendar}

\section{3-1924}

1923

June 6-12. Wednesday-Tuesday, Second Semester Examinations.

June 8. Friday, 1:30 p. m., Annual Meeting of Board of Trustees.

June 8. Friday, 8:30 p. m., Recital, Conservatory of Music.

June 9. Saturday, 8:15 p. m., Senior Class Play.

June 10. Sunday, 10:30 a. m., Baccalaureate Sermon.

June 11. Monday, 11:00 a. m., Extemporaneous Speaking Contest.

June 11. Monday, 8:15 p. m., Senior Class Play.

June 12. Tuesday, 11:00 a. m., Class Day Exercises.

June 12. Tuesday, 6:30 p. m., Alumni Banquet.

June 13. Wednesday, 10:30 a. m., Thirty-fourth Annual Commencement.

June 13. Wednesday, 1:00 p. m., College Luncheon.

June 13. Wednesday, 8:30 p. m., President's Reception.

Sept. 17-19. Monday-Wednesday, Registration days.

Sept. 19. Wednesday, 10:30 a. m., First Semester begins.

Nov. 29. Thursday, Thanksgiving Day.

Dec. 19. Wednesday, 4:20 p. m., Christmas Vacation begins.

1924

Jan. 3. Thursday, 8:00 a. m., Christmas Vacation ends.

Jan. 28-Feb. 1. Monday-Friday, First Semester Examinations and Second Semester Registration.

Feb. 5. Tuesday, 8:00 a. m., Second Semester begins.

Feb. 12. Tuesday, Lincoln's Birthday.

Feb. 22. Friday, Washington's Birthday.

Mar. 4. Tuesday, Cap and Gown Day.

April 1. Tuesday, Last Day for Submitting Senior Theses.

April 17. Thursday, 4:20 p. m., Spring Vacation begins.

April 24. Thursday, 8:00 a. m., Spring Vacation ends.

May 30. Friday, Memorial Day.

June 2-7. Monday-Saturday, Second Semester Examinations.

June 11. Wednesday, Second Semester ends. 


\title{
Administrative Officers
}

\author{
RICHARD U. JONES, Dean. \\ Curriculum, Student Activities and College Policies. \\ JOHN P. HALL, Registrar. \\ Catalog, Grades, Credits, Entrance Requirements.
}

HARRY PHILLIPS, Director Conservatory of Music.

Catalog, Tuition, Entrance.

ALICE M. CLOUGH, House Director of Wallace Hall.

ROBERT S. WALLACE, Business Secretary.

BISHOP H. SCHRIBER, Secretary and Attorney. Records, Taxes, Litigation, Release of Mortgage.

Pioneer Building, St. Paul.

RUFUS C. JEFFERSON, Chairman Finance Committee.

Endowment Investments.

Merchants National Bank Building, St. Paul.

E. B. KIRK, Treasurer.

Capital National Bank, St. Paul.

GILBERT L. WILSON, Field Executive.

LEAH M. de ZOUCHE, Accountant. 


\section{Board of Trustees}

\section{Officers of the Board}

G. D. Dayton . . . . . . . . . . . . . . . . . . . . President

R. C. Jefrerson....................... Vice-President

B. H. SchribER $\ldots \ldots \ldots \ldots \ldots \ldots \ldots \ldots \ldots \ldots \ldots \ldots \ldots$ Secretary

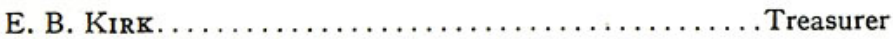

\section{Trustees}

Terms Expire June, 1923

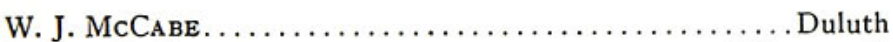

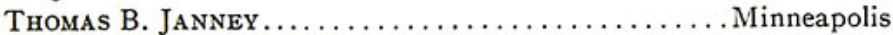

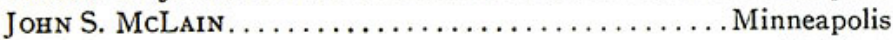

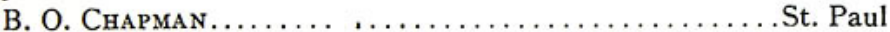

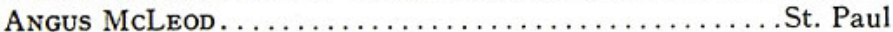
Rev. MuRdoCh MCLEOD, D. D . . . . . . . . . . . Minneapolis

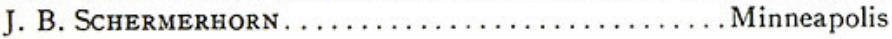

Terms Expire June, 1924

Rev. H. C. Swearingen, D. D. . . . . . . . . . . . . Paul

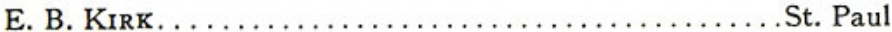
Rev. John E. Bushnell, D. D .................. Minneapolis Watson P. DavidSon . . . . . . . . . . . . . . . . . . . .

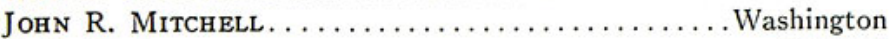

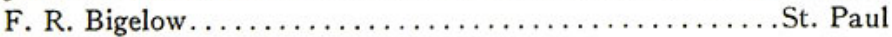
C. L. Hilton . . . . . . . . . . . .

TERMS EXPIRE June, 1925

Charles H. Bigelow St. Paul George D. DAyton. Minneapolis

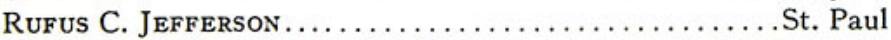

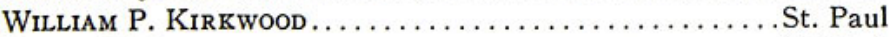
Bishop H. Schriber. . . . . . . . . . . . . . . . . . . . Charles V. Smith . . . . . . . . . . . . . . . . . . . . Louis H. Williams. Minneapolis GEORGE W. WISHARD Minneapolis 


\title{
Committees of the Board of Trustees
}

\section{Executive Committee}
B. H. Schriber, Secretary
T. B. JANNEY
E. B. KIRK
C. H. BigelOW
R. C. JEFFERSON
C. V. SMITH
H. C. Swearingen
GEO. D. DAYTON

B. O. Chapman

\section{Committee on Investments}
Geo. D. Dayton
J. B. SCHERMERHORN
C. H. BigelOW
B. H. SCHRIBER
F. R. BIGELOW
C. V. SMITH

\section{Committee on Instruction}
J. S. MCLain
MURDOCH MCLEOD
C. L. HiLTON
H. C. SWEARINGEN
J. E. BuSHNELL
W. P. KIRKWOOD

Committee on Property

R. C. JEFFERSON

ANGUS MCLEOD
W. P. Davidson

E. B. KIRK

J. B. SCHERMERHORN

Committee on Campus

H. C. Swearingen

GEO. D. DAYTON
C. H. Bigelow

B. H. SCHRIBER

\section{Committee on Annuities}
C. V. Smith
B. H. SCHRIbER
Geo. D. Dayton

Committee on Budget and Expenditures
B. O. Chapman
L. H. Williams
E. B. KIRK
B. H. SCHRIBER

\author{
C. H. Bigelow \\ Committee on Commencement \\ H. C. Swearingen \\ Committee on Endowment \\ R. C. JeFFERSON \\ H. C. SWEARINGEN \\ J. B. SCHERMERHORN
}

Geo. D. Dayton, Chairman

B. H. SCHRIBER, Secretary

G. W. Wishard 


\title{
College Faculty
}

\author{
HENRY CHAPMAN SWEARINGEN., D. D. \\ President, Pro Tempore. \\ Residence, 780 Summit Avenue. Dale 0392.
}

\begin{abstract}
JAMES WALLACE, Ph. D., LL. D., Professor of Bible. Head Professor of Bible Training Department.

On the Frederick Weyerhaeuser Foundation. Residence, 68 South Snelling Avenue. Midway 2178.
\end{abstract}

ANDREW WORK ANDERSON, A. M., Secretary. Professor of Philosophy and Education. On the O. A. Robertson Foundation.

Residence, 68 South Snelling Avenue. Midway 2178.

DAVID NEWTON KINGERY, A. M., Professor of Mathematics and Astronomy. Residence, 135 Amherst Street. Midway 3658.

JULiA MacFARLANE JOHNSON, A. M., Professor of English Literature and Old English. Residence, 63 Macalester Avenue. Midway 7689.

HENRY DANIEL FUNK, A. M., Professor of History.

Residence, 195 Macalester Avenue. Midway 2129.

RICHARD URIAHYJONES, A. M., Dean.

Professor of Chemistry.

Residence, 211 Amherst Street. Midway 1881. 
HUGH STUART ALEXANDER, A. M., Professor of Physics and Geology.

Residence, 1710 Portland Avenue. Midway 1080.

JOHN PORTER HALL, A. B., Registrar, Professor of Greek.

Residence, 1835 Dayton Avenue. Midway 3735.

GEORGE WILLIAM DAVIS, Ph. D., D. D.,

Professor of Social and Political Science.

Residence, 1596 Summit Avenue. Midway 1152.

GLENN CLARK, A. M., Professor of English.

Residence, 1787 Goodrich Avenue. Midway 1620.

J. CHARLES HAZZARD, Ph. D., Professor of Latin.

Residence, 1746 Stanford Avenue. Nestor 5930.

FREDERIC GIBBS AXTELL, A. M., Librarian. Associate Professor of Bibliography. Residence, 181 Vernon Avenue. Midway 1366.

AUGUSTA HALLIE CHALFANT, A. M., Associate Professor of German and Spanish.

Residence, 1636 Hague Avenue. Midway 6885.

*FARQUHAR DAVID McRAE, Ph. D., D. D., Associate Professor of Social Service and History.

GILBERT LIVINGSTON WILSON, Ph. D., Field Executive, Associate Professor of Anthropology.

Residence, 1922 Ashland Avenue. Midway 7228.

CLARA H. LORENZEN, A. B., Dean of Women.

Associate Professor of Psychology.

Residence, 1632 Summit Avenue. Midway 1087.

OTTO T. WALTER, Ph. D., Associate Professor of Biology.

Residence, 1602 Palace Street. Nestor 3759.

RALPH WILLIAM THACKER, A. B., Associate Professor of Physical Education.

Residence, 1905 Portland Avenue. Midway 3941. 
MARGARET ANDERSON, A. M., Associate Professor of French. Residence, 1628 Laurel Avenue. Midway 0375.

GRACE BEE WHITRIDGE, Adjunct Professor of Dramatic Art and English. Residence, 654 Hague Avenue. Dale 0301.

HELEN JULIA KELLOGG, A. B., Adjunct Professor of French.

Residence, 877 Goodrich Avenue. Dale 6135.

MARGARET MAcGREGOR DOTY, A. B., Adjunct Professor of English.

Residence, 1708 Marshall Avenue. Midway 0623.

PAUL GROSSHUESCH, A. B., Instructor in German.

Residence, 952 Reaney Street. Tower 3166.

GRACE EMILY KAY, A. B., Instructor in Theoretical Music.

Residence, 587 Laurel Avenue. Dale 7141.

RUTH GLADYS ISKER, A. B., Instructor in Vocation.

Residence, 3116 Emerson Avenue S., Minneapolis.

NINA PURCELL GUNNISON, A. B.,

Instructor in Religious Education.

Residence, 3300 Stevens Avenue, Minneapolis.

GRACE MARIE GUILFORD, A. B., Instructor in English.

Residence, 4315 Blaisdell Avenue S., Minneapolis.

VERN L. BERRYMAN, A. B.,

Instructor in History.

Residence, 1683 Hewitt Avenue.

HELEN EVA BRIGGS,

Lecturer in History of Fine Arts.

Residence, 1653 Lincoln Avenue. Midway 1546.

ETHEL CROCKER, B. S.,

Physical Training for Women.

SARAH ELIZABETH MacKNIGHT, A. B., Secretary to the President and the Registrar. Residence, 355 St. Anthony Avenue. Dale 6092. 


\section{Committees of the Faculty}

\section{Rules and Discipline}

R. U. JONES

R. U. JONES

H. D. FUNK

F. G. Axtell

James WALlace

J. P. HaLl
A. W. ANDERSON

Clara Lorenzen

\section{Curriculum}

G. W. Davis

A. W. ANDERSON

J. C. HazZARD

\section{Library}

\section{Catalog}
A. W. ANDERSON
D. N. KINGERY

H. S. ALEXANDER

A. H. Chalfant

\section{Program}
A. W. ANDERSON
O. T. WALTER

Matriculation and Evaluation of Credits

J. P. HALL

R. U. JoNes

Religious Life and Activities
James Wallace
G. W. Davis
JULia M. JoHnson
H. D. FUNK
G. L. WILSON

\section{Buildings and Grounds}

Grace B. Whitridge

D. N. KINGERY

H. S. Alexander

R. S. WALLACE

\section{Pi Phi Epsilon and Scholarships}
A. W. ANDERSON
O. T. WALTER

J. P. HaLL

MARgaret ANDERson

\section{Student Gourses}

R. U. JONES

J. P. HaLL

Clara Lorenzen

\section{Social Affairs}

Clara Lorenzen

Grace B. Whitridge
GlenN Clark

A. H. Chalfant

MARgaret M. Doty 


\section{Athletics}
H. D. FUNK
R. W. THACKER
A. W. ANDERSON

\section{Publications and Forensics}

J. C. HAZZARD

Grace B. Whitridge
Glenn Clark

Helen J. Kellogg

\section{Vocational Bureau}
H. D. FUNK
MARgaret ANDERSON
O. T. WALter
J. P. HALL
Helen J. Kellogg

\section{Publicity}
G. L. WILSON
J. C. Hazzard
Glenn Clark
J. P. Hall
R. W. THACKER

\section{Commencement Exercises}

H. D. FUNK

F. G. Axtell Grace B. Whitridge

\section{Honorary Degrees}

James WALlace

G. W. Davis

R. U. JONES

Rhodes Scholarships

G. W. Davis

James Wallace

\section{Nominating Committee}
G. W. Davis
A. W. ANDERSon
R. U. JONES
H. D. FUNK
JULIA M. JOHNSON

The President of the College is ex-officio a member of each faculty committee. 


\title{
In Memory \\ of the
}

Reverend Farquhar David McRae Ph. D.

Associate Professor of Social Service and History

\author{
BORN \\ January 16, 1862 \\ DIED \\ January 18, 1923
}

Scholar and Christian

And he shall be like a tree planted by the streams of water. 


\section{General Information}

\section{Historical Sketch}

Macalester College was opened on September 15, 1885. It is the outgrowth of two academies founded by the distinguished Minnesota pioneer missionary and educator, the Rev. Edward Duffield Neill, D. D. One of these schools was founded in St. Paul, in 1853; the other was established in Minneapolis, in 1873. Both were named after Mr. M. W. Baldwin, the famous locomotive builder, who was a close friend of Dr. Neill and a financial supporter of his first educational undertaking. In $1873 \mathrm{Dr}$. Neill solicited aid from Mr. Charles Macalester of Philadelphia for the purpose of developing the Baldwin School into an undenominational college of the New England type. The latter gave for this purpose the noted summer hotel at St. Anthony Falls, known as the Winslow House. In appreciation of this gift the proposed institution was named Macalester College, March 5, 1874.

Failing in his effort to secure adequate endowment for this college for men only, Dr. Neill asked the Synod of the Presbyterian Church of Minnesota to adopt this college as a denominational institution. On October 15, 1880, by action of the Synod, it passed under Presbyterian control. The trustees of the college, in 1883, donated to the institution the forty acres on which it is now established. They then sold the Winslow House and from the proceeds thereof, in 1884 , erected the east wing of the present main building. The same year the Synod completed an endowment of $\$ 25,000$ for the president's chair, and in 1885 the institution was opened to students. At its opening the faculty numbered five professors; the student body was composed of six college freshmen, and fifty-two preparing for college in Baldwin School.

Because of the insufficiency of its resources financial difficulties multiplied fast after the opening of the college. In 1887 its net liabilities were over $\$ 37,000$. Despite this debt the trustees proceeded to erect the main building at a cost of $\$ 68,000$ and increased the indebtedness, by January 1,1889 , to $\$ 103,000$. During the next ten years these liabilities grew larger until they totaled $\$ 180,000$, and the college seemed hodelessly burdened with debt. Three presi- 
dents gave up the attempt to save the institution. But a group of loyal professors, led by the inspiring example of Dr. James Wallace, believed in the future of the college and kept its doors open.

From 1889 to 1898 Macalester College graduated one hundred students. In 1893 the college was made coeducational. Such was the character of the young men and women, who became alumni, that Christian people began to realize that Macalester College was doing an indispensable work for the Church and declared the institution must be saved.

Among the most active in this cause were Messrs. R. A. Kirk, R. C. Jefferson, George D. Dayton, Thomas H. Dickson and Professor Thomas Shaw. These influential men enlisted the financial support of many friends and in July, 1900, reported that the old debt had been liquidated.

Meantime, in June, 1900, they effected a reorganization of the Board of Trustees. In 1904 the first endowment campaign for $\$ 300,000$ was launched. In July, 1911, the trustees announced that they had not only completed this endowment, but that they had, in addition, erected two new, modern buildings: Wallace Hall and the Carnegie Science Hall. In January, 1913, at the request of $\mathrm{Mr}$. Frederick Weyerhaeuser the trustees undertook the raising of a second endowment fund of $\$ 250,000$, which was all paid in during 1916.

The rapid growth of the college necessitated the discontinuance of the Baldwin School in 1914. In 1918 the trustees, impelled by the growing demands of the institution, moved to secure a third endowment fund and fixed their goal at $\$ 750,000$. As a result of a state-wide campaign in 1920 Minnesota pledged nearly $\$ 600,000$, of which $\$ 465,000$ came from the Twin Cities. Three large contributions were received from outside of the State: $\$ 200,000$ from the General Education Board; $\$ 75,000$ from the Carnegie Foundation; and $\$ 25,000$ from the Presbyterian Board of Education. Students, alumni and friends outside the State contributed over $\$ 21,000$. When the campaign was finished the gratifying sum of $\$ 915,220$ had been pledged, which is almost all paid in now. The total endowment of Macalester College is thereby raised to about $\$ 1,500,000$. Along with the increase of financial strength, the alumni, students and faculty of the college have grown in numbers, and its influence has spread. The history of Macalester in the last twenty years is, indeed, a record of honorable achievement. 


\section{Presidents of Macalester College}

Rev. Edward Duffield Neill, D. D., 1873-1884.

Rev. Thomas A. McCurdy, * D. D., 1884-1890.

Rev. David James BurRell, D. D., 1890-1891.

Rev. AdAM Weir Ringland, D. D., 1892-1894.

Prof. James Wallace, Ph. D., LL. D., 1894-1906.

Prof. Thomas Morey Hodgman, LL. D., 1907-1917.

Rev. Elmer Allen Bess, D. D., 1918-1923.

\section{Form of Bequest} College.

The corporate name of the institution is Trustees of Macalester

Legal Form of Bequest.-I give and bequeath to the Trustees of Macalester College of St. Paul, Minnesota, duly incorporated under the laws of Minnesota, the sum of.$\ldots \ldots \ldots \ldots \ldots$. dollars.

\section{Location}

Macalester College is located in Macalester Park, St. Paul, a beautiful suburb in the so-called Midway District. The location is favorable for study, for the development of a pure and wholesome college life, and for careful supervision of the conduct of students. Easy access to the Twin Cities is afforded by the Grand Avenue and Snelling Avenue electric lines-the latter of which connects with the interurban lines. This combination of college and city life is a unique advantage to Macalester students. The public libraries, churches, lecture courses and musical entertainments of these cities offer cultural opportunities and the vocations in city life can be studied at first hand.

\section{Campus}

The campus contains forty acres with a frontage of six hundred and sixty feet on Summit Avenue. The college buildings are situated on the north half of the campus, while the ample athletic field and college woods occupy the southern half.

\section{Buildings and Equipment}

The Main Building contains class rooms, society halls, library, auditorium and executive office. 
The Carnegie Science Hall is the gift of Mr. Andrew Carnegie. The basement contains a wood shop and a metal shop for applied mechanics. The first floor is devoted to physics and mineralogy; the second to biology, mathematics and astronomy; and the third to chemistry. Electrical connections are provided in all of the lecture rooms for general demonstrations and lectures.

Museum.-The Lewis Collection of Indian relics is rare and valuable, as is also the Educational Collection of marine invertebrates and fishes contributed by the Smithsonian Institution, Washington, D. C. There is also a collection of about five hundred specimens, obtained and loaned by Gilbert L. Wilson, Ph. D., illustrating the culture of the Hidatsa and Mandan Indians. This collection includes sets of Hidatsa agricultural tools, household utensils, pipes, weapons and other objects.

The Men's Dormitory contains twenty double rooms designed to accommodate two students each. The building is heated by steam and lighted by electricity.

Wallace Hall, situated at the corner of Summit and Macalester Avenues, one block from the main campus, is the dormitory for women, accommodating ninety-three students. This is a thoroly modern fire-proof building. Besides the rooms for the young women there are three large parlors, a dining room seating one hundred, a gymnasium in which all of the classes in physical training for women are held and the music rooms, where the Conservatory of Music meets its students. The building is steam heated and electric lighted.

Drawing of rooms by upper class women occurs in the spring and freshman rooms are assigned in the order of application, usually before commencement.

Student government is organized at Wallace Hall, which in conjunction with the Dean of Women regulates the life of the Hall, in conformity to the customs and ideals of Macalester College.

Miss Aiice M. Clough presides here as House Director, and the Dean of Women, Miss Clara Lorenzen, has her residence at Wallace Hall.

Rice Hall, named in memory of Rev. Daniel Rice, D. D., a former professor and trustee, is a frame building facing the campus, used as a practice hall by the School of Music.

Shaw Athletic Field, which was dedicated at the opening of the school year in 1909, was named in honor of Professor Thomas Shaw 
former President of the Board of Trustees, on account of his interest and assistance in the athletics of the institution. It contains four acres of the campus lying directly south of the main buildings.

\section{Library}

The Edward D. Neill Library contains about 16,300 volumes. The working collection is located on the third floor of the Main Building; less used books are on other floors. For greater security the Neill collection has been placed in the museum room in Science Hall; in this building also are department libraries.

The Neill collection, consisting for the most part of books presented by Dr. Neill or acquired during his librarianship, contains Americana and some sixteenth and seventeenth century editions in theology and the classics; there are fifteen hundred volumes and a valuable collection of autograph letters.

The Dewey system of classification is used.

One hundred periodicals are on file in the Library or in the department libraries.

For maintenance of the Library there is set apart each semester two dollars and fifty cents of each tuition fee.

Henry L. Moss, a trustee of the college until his death in 1902, and his wife Amanda H. Moss, who died in 1910, bequeathed to the College property which has added about $\$ 7,500$ to the endowment and produces for the Library $\$ 450$.

The Library is open as follows: Monday to Friday, from eight until five o'clock; Saturday, from eight to twelve, and one-thirty to five o'clock; holidays, nine to twelve, and one-thirty to five o'clock.

\section{Other Library Privileges}

The St. Paul Public Library contains, in its central building, 261,000 volumes. Of first importance to College students is the Social Science Reference room, which contains the library's resources in economics, politics, sociology, education, and social work. There is also a reference room for the useful arts and one for the fine arts, including music. This library is located within fifteen minutes' ride by street car from Macalester College. Students may draw books for home use. 
The James Jerome Hill Reference Library, recently opened, has a most carefully chosen collection of books on all subjects except law and medicine. In a special room is a noteworthy map collection. This library supplements the resources of other accessible libraries and affords unusual opportunities for study and research. College faculties and students are requested to use it freely. The James Jerome Hill Reference Library forms the east wing of the Public Library Building.

The library of the Minnesota Historical Society contains about 165,000 books and pamphlets. In addition to its very large collection on American local history it contains much material on the Northwest and Canada, also one of the largest collections in genealogy and biography in the United States, and an extensive collection relating to the Scandinavians in America. This library building is located near the State Capitol.

Other libraries open to students are the State Law Library, The Board of Control, Tax Commission and Labor Commission libraries, also the Minneapolis Public Library, which has 245,000 volumes in its central building.

Occasional use is made of the libraries of the University of Minnesota, the College of Agriculture and the Ramsey County Medical Society. 


\section{Administration}

In the administration of the college appeal is made to the selfrespect and honor of the students. They are constantly encouraged to guard well their honor and that of the institution, and to main. tain a wholesome esprit de corps.

Some regulations, however, are necessary, and when students matriculate it is understood that they thereby submit themselves to the government of the college and pledge themselves to support the same while they are members of the institution. They are expected, and, by virtue of their matriculation as students of the institution, are understood to obligate themselves to act as ladies and gentlemen, to be faithful in attendance upon recitations, examinations, daily morning prayers, and Sunday morning service, and to be diligent in preparation of all tasks assigned.

Parents and prospective students should note that no fraternities are permitted, no smoking on the campus or in any of the college buildings by faculty, employees or students and no dancing engaged in by both men and women at any college function. It is from no Puritanic attitude nor from any desire to be peculiar that the college makes these prohibitions, but because scholarship and the best interests of the student body are served thereby.

Students whose influence is found to be hurtful, even though guilty of no serious breaches of order, will not be retained in the institution.

The dormitories are organized on the self-government plan under faculty cooperation.

\section{Cooperation of Students}

The policy of the college is to invite a friendly cooperation of the students. Personal contact of faculty and students renders unnecessary any large number of rigid rules and encourages free dom of initiation and execution on the part of the student body. In an especial degree upper classmen, who have received the benefit of this system of conducting the institution, are expected to be the friendly advisers of the lower classmen. It is among the advantages of a private institution that it can outline such a plan and expect its realization. 


\section{Registration}

Students are required to register by the beginning of each semester. In case of delay in registration beyond the registration days indicated in the college calendar, a fine of one dollar will be imposed for the first day and fifty cents for each subsequent day. No excuses will be granted for late registration. Students may register by mail on deposit of tuition fee, subject to the entrance requirements stated on page 32 .

No student is permitted to register after the fourth Monday of the semester.

Students registering later than the second Monday of the semester are required to secure permission from the heads of the departments in their respective courses.

The matter of excess registration is to be referred to the deans.

The student who has failed in more than half the work of one semester, counted by hours, may not register for the following semester.

The prospective student should procure from the college (1) an application blank in which his high school credits should be entered by the principal or superintendent and mailed by the proper school authority to the Registrar by the first of August; (2) a questionnaire to be answered by the student for examination and approval by the President.

By means of the selective system, based on the above, the college authorities will limit the number of new students to be received each year.

\section{Examinations and Reports}

Examinations are held at the close of each semester. A record is kept of each student's grades, a copy of which is sent to the parent or guardian at the close of each semester.

Students who secure a passing mark in a course are graded as follows: A, B, C or D, which mean excellent, good, fair and poor, respectively. Students who do not reach a passing mark are graded as follows: Con, I or F. Con, meaning condition, implies that the student has failed in the final examination and that the deficiency may be removed by his passing in a second examination to be given later. I means that the mark is withheld by the instructor because the work required has not been completed. F means failure in term 
grade. In cases of failure students may secure credit only by repeating the course entire. A Con becomes an $\mathrm{F}$ upon failure to pass the second examination.

Conditions incurred in courses of the first semester must be removed by examination within the first six weeks of the second semester; conditions incurred in courses of the second semester must be removed within the first two weeks of the following semester.

For privale and condition examinations a fee of fifty cents shall be paid for each examination to the Secretary, who shall thereupon issue a permit. Private examinations will be authorized by the faculty only, and for the most urgent reasons stated in writing.

\section{Degrees}

Graduates of the College of Liberal Arts receive the degree of Bachelor of Arts. The degree of Bachelor of Music is granted to students who fulfill the requirements for such degree in the Conservatory of Music.

No student shall be entitled to graduate who shall not have been attending the college at least one year.

\section{Fellowships}

The Board of Trustees has offered a limited number of fellowships open to graduates of Macalester College and carrying a yearly stipend of $\$ 800$. The holders are required to devote their time to instruction in the college and to graduate study in the University of Minnesota.

\section{Prizes and Scholarships}

Noyes Prize.-Mrs. D. R. Noyes has given $\$ 2,000$, the interest on which is used as prizes for student scholarship. Last year the senior prize was awarded to Margarette McNaughton, the junior to Ralph Baerman and the sophomore to Vida McNaughton.

Stringer Prize.-In honor of the memory of Mr. E. C. Stringer the college is able to offer an annual prize of twenty-five dollars, to be given to that student of the college, who, having not fewer than fourteen recitations a week, takes the first place in the preliminary oratorical contest, and represents the college in the state contest. Awarded this year to Robert Haskin. 
Paul Prizes In Extemporaneous Speaking.-In 1917 Rev. W. F. Paul of Minneapolis established the Paul Contest in Extemporaneous Speaking to be held annually during Commencement Week. For this purpose he offers each year prizes totaling fifty dollars, divided into three prizes of thirty, fifteen and five dollars. First prize was won in 1922 by Robert Haskin.

Shaw Scholarship.-Given by Professor Thomas Shaw, of St. Paul, to the nominee of the Central Presbyterian Church, of St. Paul, yielding $\$ 50$ per annum. Awarded this year to Margaret McPhee.

Silliman Scholarship.-Offered by Mr. H. B. Silliman, of Cohoes, N. Y., and yielding $\$ 50$ per annum. Awarded this year to Victor Jacobson.

Williams Brothers. Scholarship.-Louis H. and Charles R. Williams, of Minneapolis, have given $\$ 1,000$, the income from which is for the aid of a student selected by the faculty. Held this year by Archie Cummings.

Webb Scholarship.-Mr. E. A. Webb, deceased, gave $\$ 1,000$, the interest of which is to aid a candidate from the Central Presbyterian Church, St. Paul. Held this year by Marian Mills.

Winona Scholarship.-The First Presbyterian Church has given $\$ 1,000$, the interest of which is to aid a candidate nominated by this church.

Biology Scholarship.-Dr. Archibald MacLaren, of St. Paul, contributes $\$ 50$ to aid a student in the department of biology, to be selected by the head of this department. Held this year by Dorothy Olds.

New England Scholarship.-The St. Paul Colony of New England women gives this year $\$ 60$ to a young woman of New England parentage.

Scott Scholarship.-Mr. William H. Scott, of Philadelphia, gives $\$ 60$ for a scholarship awarded by the faculty. Awarded this year to Dora Koberg. 
Went McCabe Scholarship.-Bequeathed by Edward Everett McCabe of the class of 1914 and accepted as a general scholarship. Awarded this year to Catherine Bates.

Crawford Scholarship.-A gift of $\$ 1,000$ in memory of Ira Leslie Crawford, the income of which is devoted to a general scholarship. Awarded this year to Mary Gwen Owen.

Myers Scholarship.-S. F. W. Myers has given, in memory of his son, Carl Bertram Myers, $\$ 1,000$, the income from which is for the aid of men preparing for the Christian ministry.

Macalester Scholarship of St. Paul Presbytery.-Amounting now to $\$ 890$, interest of which is to aid a student nominated by the Presbytery of St. Paul. Awarded this year to Monty Charlsen.

James Mulvey Memorial Scholarship Fund of the First Presbyterian Church of Stillwater.-Founded by subscriptions of $\$ 1,100$ each by the Misses Jessie and Edna Mulvey in memory of their father; increased by gifts of the Stillwater Presbyterian church; amounts now paid in total $\$ 1,875$. Interest to aid a student nominated by the Stillwater church. Held this year by Stanley Dietz.

Ministerial Scholarships.-Given by Board of Education of the Presbyterian Church to candidates for its ministry, and to men and women candidates for missionary service.

War Service Scholarships.-The Presbyterian Church has provided a fund, administered by the General Board of Education, for ex-service men, who may require financial aid in the pursuit of study in preparation for their life work.

Honorary Scholarships are offered to the first ranking student among the young men and also among the young women in each graduating class of an accredited four-year high school, provided the superintendent certifies that such students are of honor grade and their questionnaires are approved by the President. Dependent on the average grade during the freshman year, C, B or A, these scholarships are $\$ 60, \$ 75$ or $\$ 100$.

Rhodes Scholarships.- "In order to keep this well known bequest before the minds of present or prospective students it is briefly mentioned. Circulars of full information can be obtained at the president's office. Any male student who is a citizen of the United States, unmarried, not less than nineteen nor more than twenty-four years of age and who has reached the end of his sophomore year of study, may be a candidate for one of the Minnesota scholarships. This insures to the winning contestants a three years' residence in Oxford' University, England."

Loan Fund.-A loan fund of one thousand dollars is held by the Faculty Women's Club. This fund is used as a loan for short periods, without interest, preferably to junior and senior students. 


\section{Student Activities}

The Y. M. C. A. has a membership of about eighty students. It holds its regular meeting every Tuesday morning. A committee of the association is present at the college two or three days before the opening of the first semester to assist the new students. The president of this association is F. L. White.

The Y. W. C. A. offers social, educational and religious advantages to the women of the college. It binds all the women together into one common fellowship of love and service thru its regular Tuesday morning meetings, Mission and Bible study classes as well as socials. The president of the association is Dorothy Olds.

Literary Societies.-In the college there are seven literary societies under the general oversight of the faculty. The Hyperion society admits to membership both men and women; the Athenaean, Alethean and Eulogian societies admit men, and the Clionian, Philotian and Thalian societies, women.

No literary society or other student organization may be established without the consent of the faculty.

The Quill Club.-Students whose work in the English Department is of sufficient merit to be published in the Gateway Magazine are eligible for membership in the Quill Club. Meetings of the club are held every two weeks when a literary program is given.

Macalester College was the sixth in the United States to be admitted to the American College Quill Club.

The Macalester Players is a group within the Department of Expression, whose object is to stimulate and develop an appreciation of the best in drama. Several plays are given each year, coached by the head of the department.

Debate and Oratory.-All matters pertaining to debate and oratory are under the charge of the Forensic Board. This Board is composed of one representative from each literary society, one from each class and two representatives from the faculty. 
This year the college has taken part in intercollegiate debates with the following institutions: Northland College, Lawrence College, St. Olaf College, Gustavus Adolphus College and Hamline University.

The college takes part in the State Intercollegiate Contest in Oratory and in contests in extemporaneous speaking with the University of North Dakota and with Hamline University. A preliminary home contest is held for each of these contests, for which suitable prizes are offered.

Interscholastic Forensic Competition.-Macalester College has taken a great interest in developing a more natural, effective manner of public speaking among the high schools of the state. To further that end it organized the Minnesota High School Discussion League which is now starting on its ninth year, and the High School League in Extemporaneous Speaking which is starting on its seventh year. The state has been organized into districts and the winners of the district contests come to Macalester the third week in February where the state contests are held. Macalester College furnishes medals for the winners of district and state contests and shields for the winning schools.

A circular containing detailed statement of the plan and rules of the contests can be obtained by addressing Professor J. C. Hazzard, Macalester College.

\section{Honorary Forensic Fraternity}

Pi Kappa Delta is a national honorary fraternity, organized to give recognition to those who distinguish themselves in public speaking, and to promote interest in forensics.

The Charter of the Macalester or Minnesota Alpha Chapter was granted by the National Council in 1920 .

Membership in Pi Kappa Delta is based on election, being limited to professors of public speaking and those who have represented the college in intercollegiate forensic contests.

The local Chapter interests itself in all forms of forensics. and has assumed the secretaryships of the Minnesota High School Discussion League and the High School League in Extemporaneous Speaking. 
College Glee Club.-This is a strong student organization, firmly established and with a splendid record of accomplishment in the nine years of its existence. The club is under the direction of a faculty adviser.

The M Club was organized December 9, 1913. It was founded to keep those who have won the letter in touch with each other and to foster athletics. When a Macalester student has earned an $M$ he becomes a member on the payment of one dollar initiation fee.

President, G. L. Brownlee, 1617 Juliet Street, St. Paul.

The Macalester Club of St. Paul was organized in 1922 by alumni in St. Paul and vicinity "to strengthen the bonds between Macalester and her alumni and former students; to increase the effectiveness of the Alumni Association; to promote the social relations of its members; to stimulate the interest of the public in and for Macalester; and to cooperate in any and all movements to advance Macalester."

Meetings are held in September, December, February and April. Graduates of Macalester College or Conservatory or Academy, former students who have been in attendance at Macalester College not less than two college years and wives or husbands of members are eligible to membership.

President, Mrs. Mildred Phillips Kindy, '10.

\section{Pi Phi Epsilon Society}

The society was organized in 1914 with twenty charter members. The aim of the society is to stimulate scholarship and intellectual interests in the college. It regards scholarship, intellectual leadership, originality and character as the requisites for eligibility to membership.

The society is now composed of twenty-seven active members. New members are chosen by the faculty in the fall of each year. Of these not more than four are taken from the sophomore class, the remainder from the junior and senior classes. Those selected from the sophomore class are chosen strictly on the basis of high standing as students, as shown by the records of the Registrar. Others are elected by ballot of the faculty from a list nominated by the advisers and heads of departments. Nomination is made on the ground of unusual proficiency in the student's major subject. After the above are chosen the faculty may elect not to exceed two more from a list that includes worthy students not otherwise eligible. At the close of the school year members of the graduating class who have exceptionally fine records thru their senior year may be added to the society.

At graduation active members become graduate members of the society, and are entitled to all its privileges except voting. Members of the faculty are honorary members of the society. There are at the present time sixty-four graduate members.

The society has an active member's pin of silver, which is presented to each new member at the recognition exercises when he enters the society, and a graduate member's pin of gold, which is presented to graduating members after the Easter vacation. 
The officers of the society are: President, Gilbert M. Stevenson; Vice-President, Edward H. Evans; Secretary, Ida S. Granholm.

The Executive Committee of the society is composed of the officers together with a faculty representative.

The list of active members is as follows:

Baerman, Ralph

Balcome, Ruth Marion

Boyden, Elbert Parker

Cadwell, Marie Sarah

Deters, Lenora Esther

Erickson, Nellie Henrietta

Evans, Edward Humphrey

Granholm, Ida Sophia

Greive, Marjorie Lucille

Hannay, Maye Elizabeth

Koberg, Dora

Leven, Nathaniel Logan

McNaughton, Vida Jean
Mills, Marian Alice

Mount, Margaret Sylvia

Olds, Dorothy Alice

Olson, Carroll Lloyd

Richardson, Hervey Morris

Scheiber, Gladys Leonora

Scott, Etta Amanda

Sobrepena, Enrique

Stevenson, Gilbert Miller

Sturgeon, Vila Beatrice

Swanson, Andrew John

Todd, George Benjamin

White, Frank Lawrence

Zozaya, Margarita

\section{Religious Life and Exercises}

Macalester was founded as a Christian college. The atmosphere of the college has always been warmly religious. The Young Men's and Young Women's Christian Associations are large and active. The city offers much opportunity for religious work. In keeping with the purpose of the founders of the college the faculty makes the following requirements:-(1) all students registering for more than five hours a week in college studies are required to include the equivalent of at least one hour a week of Bible study for the year; (2) attendance at the daily chapel exercises of the college at ten o'clock in the morning is required of all college students without exception; (3) attendance at Sunday morning church services is expected of all students and required of all who are not living at home with their parents. Students connected with churches either by membership or sympathies are expected to attend the church of their preference.

The Macalester Church has initiated a system of affiliated memberships, by which the student who wishes may retain his membership with his home church while at the same time coming into such relation with the local church at the college that he may feel that he has here a church home and center for his religious life. Students are urged to take advantage of this offered affiliation. 


\section{Physical Training and Athletics}

Three dollars of the tuition fee for each semester are set apart for the support of athletics. Students are thereby entitled to admittance to all athletic contests at Macalester and to the use of the tennis courts, skating rink and other outdoor facilities.

Classes in physical training are conducted for young women in the gymnasium of Wallace Hall. Attendance is required of freshmen.

\section{Teachers' Bureau}

The college maintains a teachers' bureau as a means of communication between graduates and superintendents and school boards desiring competent teachers. Graduates will not be recommended to positions for which they do not give good evidence of fitness. A fee of one dollar is charged for enrollment in this bureau. Those desiring to make inquiry in regard to teachers should address The Teachers' Bureau, Macalester College, St. Paul, Minnesota.

Graduates who wish to enter other callings are assisted in obtaining positions for which they are qualified.

\section{Publications}

The following publications are issued from the college:-

The Macalester College Bulletin, a quarterly devoted to the advertisement and advancement of the institution.

The Mac, a triennial publication devoted to college interests, published by the college students.

The Mac Weekly, a student publication established in 1914. It gives expression to student opinion upon matters of college life, and gives complete accounts of all college events. The editor-inchief is Edward H. Evans.

The Gateway, a literary magazine published by the members of the English composition classes. 


\section{Expenses}

Students' fees are paid at the beginning of each semester, before completion of registration and strictly in advance, as follows:-

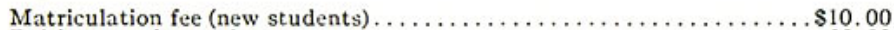

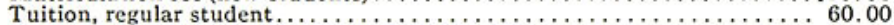

Special student (not more than eight hours) ................. 45.00

One dollar of the tuition for the first semester is applied on the salary of special coaches.

Special fees-

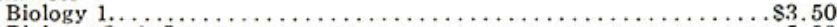

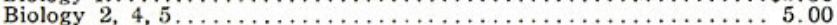

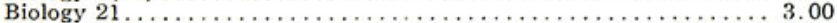

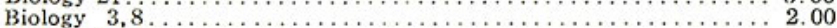

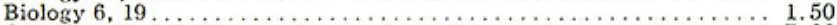

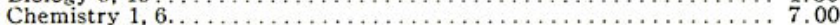

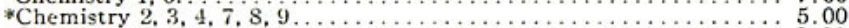

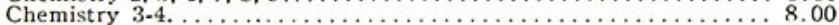

Physics $1,2,34,5, \ldots \ldots \ldots .50$

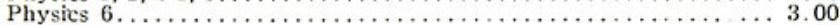

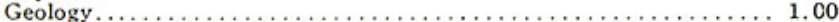

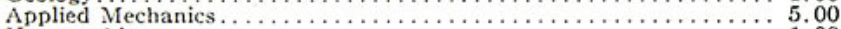

Homemaking . ........................................ 1.00

Mechanical Drawing......................................... to 1.50

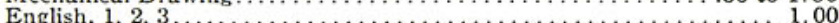

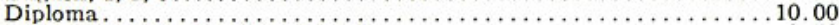

Men's guarantee fee (dormitory) ...................................

*This is a deposit fund. The actual fee charged will be based upon the cost of material.

An exchange fee will be charged on all out of town checks.

No deductions are made except for sickness lasting a month or more.

Credits are withheld until all obligations are met.

From tuition fees the trustees, on recommendation of the faculty and students, appropriate the following amounts: athletics, $\$ 3$; library, $\$ 2.50$; band, orchestra, debate and oratory, 50 cents; "The Mac," 50 cents; "Mac Weekly," \$1.25.

Refunding Tuition.-If a student leaves the institution at any time after entrance without the approval of the faculty, or because he has been suspended or dismissed, no money is refunded. Those withdrawing for other reasons, on or before the middle of a semester, will be allowed an equitable percentage on tuition paid.

\section{Special Rates}

1. Sons and daughters of ministers of any denomination are allowed a rebate of twenty per cent each semester on tuition. 
2. All candidates for the ministry, of whatever church or denomination, are allowed a rebate of twenty per cent each semester on tuition upon the following conditions:--

(1) Candidates for the Presbyterian ministry shall be under the care of presbyteries, and shall present to the treasurer certif. cations to this fact from the clerks of the presbyteries. Candidates for the ministry of other denominations shall have their purpose to enter the ministry properly certified to by the proper ecclesiastical authorities.

(2) All such students will be hell in honor bound to refund to the college treasury the amount of tuition rebated in the event of their abandoning their purpose to enter the ministry.

3. When more than one person from the same family attend college at the same time a rebate of $\$ 4$ on tuition fee will be allowed to each person after the first. This rule does not apply to those receiving other privileges or rebates.

\section{Rooms and.Board}

Room rents for all college buildings and board at Wallace Hall are to be paid in advance each month of twenty-eight days.

Wallace Hall for Women-

Board per week, each person........................\$8.00

Room rent per week, each person............................. 3.00

The trustees reserve the right, in view of possible fluctuations in cost of supplies, at the end of the first semester to raise or lower the charge for board.

Men's Dormitory-

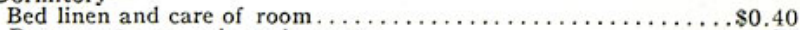

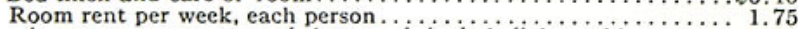
All rooms have two occupants and the rentals include light and heat.

Men students board at The Commons, or in private families. All who room at The Commons are required to board at The Commons.

Board costs on an average $\$ 6.00$ a week.

Rooms in private families per month, $\$ 6.00$ and up.

Each student in the men's dormitories is required to deposit $\$ 3.50$ (including deposit for key) as a guarantee against damage to college property, and to make it up to that amount at the opening of each semester thereafter. From this fund are deducted (1) charges for damage for which he is personally responsible; (2) charges (pro rata) for damage done in dormitories by unknown hands. The surplus, if any, is refunded to the students at the end of the year, or when they leave the dormitory. 


\section{Rooms}

(1) Furniture.-All rooms in men's dormitories are furnished with bedsteads (two-thirds size), mattresses, pillows, dresser stand, bowl and pitcher, study table, book shelves and three chairs. The toilet room lavatory is supplied with hot and cold water. Students in the dormitories must provide their own bed clothing, towels, and carpets or rugs. In Wallace Hall there are single iron beds, mattresses, pillows, dresser, study table, two rockers, two study chairs, a lavatory with hot and cold water, steam heat and electricity. Floors are of hardwood.

(2) Application.-Application for room in the dormitories should be made by the first of May to the college office. Reservation fee is $\$ 3.00$. This is applied on first month's rent. Rooms will not be held later than the opening of the term unless the room rent is advanced for the period of delay. In case applicants fail to come the reservation fee will not be returned. Rooms will be assigned in the order of application.

No deduction is made for vacations during school year either for board or room. Students are charged for their rooms until they are formally vacated - whether continuously occupied or not-and keys surrendered.

Each dormitory tenant is held responsible for the rent for the entire semester. A student may shift this responsibility by securing a new tenant not occupying dormitory quarters, but is relieved from the obligation only on withdrawal from the college for good reasons.

Students working for the college will have all bills due the college deducted from the amount due them before being paid for work performed.

Students who are in arrears at the end of any semester will be refused credits for the semester's work until all bills incurred by them have been paid; also future registration will be denied and no class work allowed until settlement satisfactory to the treasurer has been made.

Women students, who do not live at home or with relatives, and do not wish to room at Wallace Hall, are required to secure living accommodations from a list of rooms inspected and approved by the Dean of Women. Such students are expected to conform to the general social regulations in force at Wallace Hall. Any change in residence shall be made only if approved by the Dean. 


\section{Self-Support}

Students desiring to do something toward defraying their own expenses can usually find some way of doing so. Many find work on Saturdays, in stores and other places of business, and have thus paid a large part of the expense of their board. Others have earned their board by working mornings and evenings. It is seldom that any worthy, capable student with energy and tact fails to find some means by which he may work his way thru college, provided the summer vacation is improved to increase his income.

The Y. M. C. A. employment bureau has been organized to assist students in finding work. There are opportunities for work in stores and offices, caring for furnaces, waiting in clubs and carrying newspapers, and in many other ways dependent upon the student's fitness. Valuable suggestions as to employment and the financial side of college life are gladly furnished to prospective students on application and every effort to assist the new-comer is cheerfully made. Address all communications to Chairman Employment Committee, Macalester College, St. Paul.

\section{Telephone}

The college office telephones are Midway 0486; Conservatory of Music, Midway 2656; Wallace Hall, Midway 0535; Men's Dormitory, Midway 0202; Dean of the College, Midway 0166; Business Secretary, Midway 0100 . 


\section{Entrance Requirements}

\section{General Statement}

Entrance requirements are in harmony with the standards of the North Central Association of Colleges and Secondary Schools and the Association of American Colleges of which two organizations Macalester College is a member.

The satisfactory completion of fifteen units of properly coordinated work is required for admission to the freshman class of the college. The following units are required: three in English, one in Algebra and one in Geometry. Not more than four units in vocational subjects (including Agriculture, Commercial Work, Domestic Science and Manual Arts) may be presented. It is strongly recommended that the student submit two or more units of consecutive work in some foreign language. By a unit is meant four or five recitation periods a week in a subject, carried thruout a year of thirty-six weeks. The recitation periods must be not less than forty minutes in length.

Macalester College has for some time been unable to accommodate all who apply for admission. It therefore lays down certain principles of selection in justice to the students and to itself.

First, the student should have sufficient capacity and adaptability to profit by attendance at the college. Capacity is indicated by the application blank filled out by the student's high school principal. The college may, at its discretion, require mental tests, in addition. Adaptability will usually be determined, in a preliminary way, thru a questionnaire or a conference with the President. In the case of students who live at a distance correspondence and recommendations may take the place of a questionnaire or an interview.

Second, the college will give the preference to students who plan to stay a longer period of time over those proposing to remain a shorter time. Accordingly, applicants are required to state their plans with respect to college and technical education. Applicants expecting to remain at Macalester College for a full three or four years will receive the preference. If accommodations remain a certain number of serious students expecting to remain two years will be admitted. The entrance of students expecting to remain but a single year is discouraged. 


\section{Admission by Certificate}

From Accredited High Schools and Academies.-Graduates of accredited high schools and academies requiring a four-year course are admitted without condition to the freshman class, subject to the requirement of the preceding paragraph. Accredited schools are those on the list of the North Central Association of Colleges and Secondary Schools, the list of Minnesota high schools prepared by the State Superintendent and similar lists of the high schools of other states.

Applicants for admission to the freshman class should apply to the Registrar for the Applicant's Blank, which should be filled out by the principal of the high school or academy in which their courses were taken, and mailed by him to the Registrar by the first of August.

From Unaccredited High Schools and Academies.Graduates of such schools should secure the Applicant's Blank from the Registrar of the college, and have it filled out and sent to the Registrar as in the case of Accredited Schools. The credits will then be evaluated by the Matriculation Committee of the College and if satisfactory the student will be admitted.

\section{Admission by Examination}

Students not presenting certificates as provided for above must present a course of study equal to a four-year high school course. Such students will be examined in the course presented by them and will be admitted to freshman standing on passing the examination satisfactorily. These examinations will be given on the Monday and Tuesday preceding the opening of the college in September.

\section{Suggestions to Students Preparing for Macalester College}

The following suggestions respecting high school courses are not mandatory, but may be of value to future college students, now in high school or academy.

Suggested Units.-Students intending to major in Groups I or II (see page 38), are advised to present the following units for entrance: 
English 4

Algebra $1 \frac{1}{2}$ or 1

Latin 4

Modern Language 2

Geometry $11 / 2$ or 1

The remaining units may be selected from the following:

History 1 or 2

Physics 1

German 2

Greek 2

Civics $1 / 2$

French 2

Chemistry 1

Botany $1 / 2$ or 1

Physiology $1 / 2$ or 1

Zoology $1 / 2$ or 1

Physical Geography $1 / 2$ or 1

Manual Training $1 / 2$ or 1

Students intending to major in Group III are advised to present the following ten units:

English 4

German or French 2

Algebra 11/2

Chemistry or Physics 1

Geometry $11 / 2$

The remaining five units may be selected from the following:

Chemistry (if not above) 1

Botany $1 / 2$ or 1

History $1 / 2,1$ or $1 \frac{1}{2}$

Physics (if not above) 1

Zoology $1 / 2$

French 1 or 2

Physiology $1 / 2$

Greek 1 or 2

Manual Training $1 / 2$

Physical Geography $1 / 2$ or 1

German 1 or 2

Civics $1 / 2$

Suggested Courses of High School Study.-The following courses of study are suggested to students now in high schools who are preparing for entrance to Macalester College. Courses such as these will furnish substantial preparation for the work of the college and will articulate well with its courses:

Composition and Rhetoric 2 units

Literature 2 units

Algebra $11 / 2$ unit

Geometry $1 \frac{1}{2}$ unit
Latin 2 or 4 units

Greek, French or German 2 units

History and Civics 2 units

Natural Science 2 units

\section{Admission with Advanced Standing}

From Other Colleges.-Students coming from reputable institutions of collegiate grade should present letters of dismissal and are then given standing in Macalester College, allowing a fair equivalent on the course here for work done elsewhere. 
Students with failures in another college cannot be transferred to Macalester without the loss of other credits based upon an estimate of their abilities. No one dropped from the rolls of another institution because of low standing will be accepted at Macalester during the same college year.

From Normal Schools.-Credits from Normal Schools are to be reckoned according to the nature and quality of the work presented as judged by the Registration Committee. This committee consists of the Registrar and the Dean.

From High Schools and Academies.-Ordinarily, no credit will be allowed on the college course for excess units of work done in the high school or academy. A student asking for such credit should note the following conditions:-

(1) No credit will be allowed except for an excess beyond seventeen units of high school or academy work.

(2) No credit will be allowed except after an examination by the college instructors to whose departments the subjects belong.

(3) In no case will credit be given for more than half the time which the subjects consumed in the preparatory school course.

(4) The Matriculation Committee will decide which of the student's excess units may be submitted for college credit.

All credits from other institutions, for which the student wishes credit in this institution, must be presented at the time of registration. Credits presented later from other institutions will not be considered.

\section{Requirements for Graduation}

The College of Liberal Arts offers courses leading to the degree of Bachełor of Arts.

One hundred and twenty-six credits are required for graduation, the term credit meaning one hour a week for one semester in class room or two hours a week in laboratory. These credits must be secured with reference to the group from which the student has chosen his major, as follows:

\section{Required in All Courses.-}

(1) 9 credits in Religious Education, Mental Science 2, and Vocation 1. 
7 credits selected from Greek 9, History 3, Mental Science 11 and Religious Education.

At least two of these credits must be secured each year.

(2) 6 credits in English 1.

(3) 6 credits in Social and Political Science and History.

(4) 3 credits in Mental Science 1.

$\overline{31}$ credits required of all.

Major in Group I.-

(1) 28 credits in a foreign language.

(2) 14 credits in a second foreign language.

Of the above (1) and (2) at least 14 credits must be secured in college. In the case of the second language two high school units (12 credits) will suffice, but the total for both must be 42 .

One of the above languages must be Latin or Greek.

(3) 12 credits in Group III.

(4) 20 credits in the major subject.

\section{Major in Group II.-}

(1) 28 credits in one or two foreign languages. No language shall count toward this requirement in which the student offers fewer than 14 credits (or two high school units). Any part or all of this requirement may be met by entrance credits from high school.

(2) 18 credits in Group II other than the major subject and Religious Education.

(3) 12 credits in Group III.

(4) 20 credits in the major subject.

\section{Major in Group III.-}

(1) 8 credits in Mathematics 1 and 2.

(2) 14 credits in a modern language unless the student has presented 18 entrance credits in a modern language or 12 credits in one language and 6 in another.

(3) 18 credits in two subjects in Group III other than the major.

(4) 20 credits in major subject.

Extra-Curricular Credits.-For all such types of activity as Glee Club, oratory, debate, dramatics, Mac Triennial, Mac Weekly, choir, etc., no student is permitted to receive more than two credits in any one year. 
Points Required for Graduation.-In addition to the one hundred and twenty-six credits mentioned there is required an equal number of honor points, granted as follows: for each credit toward graduation earned by the student with a mark of $A$, three honor points are given; for each credit with a mark of $\mathrm{B}$, two honor points; for each credit with a mark of $C$, one honor point. A mark of $\mathrm{D}$ carries with it no honor points.

\section{Courses for the Freshman Year}

In the Freshman year the student is required to select one of the following courses according to the group in which his major will probably be.

\section{Group I.}

Religious Education 1, 2 hours One subject from Group III English 1, 3 hours Elective Latin, Greek, French or GerPersonal Hygiene man (to complete require- Physical Education ments above), 4 hours

Group II.

Religious Education 1, 2 hours English 1, 3 hours

Latin, Greek, French or German (to complete requirements above), 4 hours
One subject from Group III

One subject from Group II

Personal Hygiene

Physical Education

GRoup III.

Religious Education 1, 2 hours

English 1, 3 hours

Latin, Greek, French or German (to complete requirements above), 4 hours
Mathematics, 4 hours

One subject from Group III

Personal Hygiene

Physical Education

The elective courses for the freshman year are:-

Religious Education 1 (second semester)

Biology 1, 21

Chemistry 1

Expression 1

Foreign Language
History 1, 5, 6

Mathematics 1, 2, 9

Music

Applied Mechanics 1

Mental Science 1, 2

Social Science 1, 11 
Language requirement must be completed if possible by the end of sophomore year.

Science requirements of the student, whose major is in Group I or II, must be completed by the end of the junior year.

History and social science requirements must be completed by end of junior year.

Majors and Minors.-Each student who is working for a degree must elect by the beginning of the junior year, under restrictions stated below, one major and two minors from the eighteen following departments:-

\section{Group I.}

1. English

2. French

3. German

4. Greek

5. Latin

6. Spanish

GROUP II.

1. History

4. Religious Education

2. Music

3. Philosophy and Education

5. Social and Political Science

7. Vocation

Group III.
1. Biology
2. Chemistry
3. Geology
4. Mathematics
5. Physics

Terms Defined.-A major consists of twenty credits obtained in one department.

A minor consists of twelve credits obtained in one department.

No credit with a grade lower than $\mathrm{C}$ is counted toward a major or minor.

\section{Restrictions on Choice.-}

(1) At least one of the minors must be in a different group from the major. The minors are subject to the approval of the student's adviser.

(2) The following courses are not counted toward a major or minor:-Bible 1 (one semester) and 2, Chemistry 10, English 1, Mathematics 1 and 9.

(3) French 1-2, German 1-2, Greek 1, Latin 1-2 and 3-4, Spanish 1, Mathematics 1 and 9, Mental Science 1, Physics 1 and Social and Political Science 1 and 11 are not counted toward a major. In Physics students must present one year of high school work in the subject in order to begin a major or minor.

Five Students Required for a Class.-The college does not hold itself bound for instruction in any elective course for which 
fewer than five students make request to the Registrar. Such classes may, however, be organized at the option of the instructor.

Theses.-On or before the opening of the second semester of his junior year, each candidate for a degree shall select the subject of a thesis connected with the subject which he is making his major. This subject must be chosen in consultation with the head of the department to which the student's major belongs and with his approval.

The completed thesis shall be typewritten and filed with the Librarian on or before the first of April preceding the student's graduation. The adviser is authorized to extend the time, for sufficient reason, to a date not later than the first of May. Such thesis must be prepared according to regulations to be obtained from the Librarian, and must bear the signed approval of the head of the department. Further, these theses must be accompanied by a complete bibliography of works consulted and analysis. Ordinarily, they will not be accepted if they exceed 6,000 words in length.

\section{Classification of Students}

Classification without Conditions.-For freshman classification, as stated before, fifteen units of acceptable high school work or their equivalent; for sophomore, thirty-two college credits in addition to the entrance requirements; for junior, sixty-four credits in addition to the entrance requirements; for senior, ninetysix credits in addition to the entrance requirements.

Classification with Conditions.-A student is classified as sophomore on gaining twenty-four college credits; he is ranked junior on obtaining fifty-four college credits; he is ranked senior on obtaining ninety college credits.

All conditions from previous years must be removed by the end of the first semester of the senior year.

Change of Course.-Registration at the beginning of the semester fixes the course of study for the student. After that no change is permitted without the written consent of the instructors concerned and the student's adviser. Dropping a subject comes under this rule.

After four weeks from the opening of college no card for dropping or electing courses shall be signed except by special permission of the faculty. 
Unfinished Courses.-Students who drop a year course at the end of one semester lose all credit in that course unless some distinct phase of the subject is completed; in which case, the instructor may grant the credit.

Attending Courses as a Visitor.-Upon the approval of the adviser, a student shall be permitted to attend not to exceed four hours a week in classes for which he is not regularly registered. No credit is allowed for such attendance.

\section{Preparation for Vocations}

The system of majors and minors and the elective system in use here permit the student to frame his college course with some reference to his future vocation. In general the student will find the following courses helpful to him in his future vocational study.

For the Study of Medicine.-The following course is strongly advised for students who are preparing for the study of medicine. Those taking such a course are given a bachelor's degree upon the satisfactory completion of the first year's work in a recognized medical school.

Freshman Year

Chemistry 1 and 3

English

French or German

Mathematics 1 and 2

Vocation and Religious

Education
Sophomore Year

Biology (General Zoology and Vertebrate Anatomy)

French or German

History or Social Science

Physics

Religious Education
Junior Year

Organic Chemistry

Histology and Human Physiology

Psychology and Ethics Elective

For the Study of Law.-The value of a full college course in preparation for the study of law cannot be disputed. Macalester offers a number of courses that are invaluable to law students, and a college course arranged with this group of subjects as a nucleus is suggested below, showing also the possibility of a well rounded college course that is designed to develop the best that is in the student.

\section{Suggested Course to Law Students}

English

Freshman Year

Foreign Language

Vocation and Religious Education

Sociology and Economics

Science

History

Junior Year

Roman Law and Jurisprudence

English Constitutional History

Debate and Oratory

Religious Education

Electives

\section{Sophomore Year}

Public Speaking and Argumentation Foreign Language

Religious Education

History of Economic Theory

Psychology and Ethics

International Law

History

Religious Education

Electives 
Social Service Course.-To meet the imperative needs of our time, and in full sympathy with the practical application of Christian principles to modern conditions, the course in social service, leading to the A. B. degree, has been prepared. The student with a professional or technical career in view will find in it a solid foundation for his later special training, while those pursuing the other courses may select such numbers as will fit them to act well their parts as social citizens in the communities in which they are to live.

Macalester, by its traditions and point of view, is peculiarly well adapted to a study of this nature. Moreover, the Twin Cities and environs afford an excellent opportunity for laboratory and research work. Supplementing the resources of the college are many agencies such as the great libraries of St. Paul and Minneapolis, and a large number of public institutions of various kinds.

For the Christian Ministry and Missionary Teaching.The department of religious education and the electives in Greek Testament, philosophy, ethics and history offer a course well adapted to those who have the gospel ministry in view. Those, too, who are preparing to be missionary teachers will find in the wide range of Bible study pursued in the college an indispensable and very attractive adjunct to their course.

For Teaching.-The college has made special provision for the needs of students who wish to fit themselves for the teaching profession. The student should remember that there is the content side of his preparation and the technical side. The former part of the preparation he will obtain by directing his college studies thru the majors, minors and elective studies to the subjects which he will teach, with their related topics. The latter he will find in the courses in sociology, psychology, logic, ethics, history of philosophy, history and principles of education. This preparation will then be supplemented by practice work to increase his insight into the principles of his profession and give him skill.

For Business and Technical Vocations.-If a student has chosen his vocation before entering college special courses are offered to help him find his capacities and to develop them. He is given a thesis for his vocation that he may gather data about it. By the use of psychological methods he builds up abilities to fit him for particular positions and to guide him into a knowledge of his vocation. He is taught how to use the college courses for this purpose. 
Senior Electives in Professional Schools.-Students intending to study for some profession, who are obliged to shorten their course in preparation, may in the following manner save one year while still obtaining their degrees. After completing three years of the college course and being enrolled for the fourth year they may take the first year of a professional course in any school approved by the faculty in place of the work of the senior year.

Conditions Required.-This will be permitted subject to the following conditions: first, the required studies of the college must be completed in every case; second, a certificate must be presented from the professional school showing the successful completion of the work of the first year in that school.

Vocational Guidance-Thru the Vocation Department other courses can be suggested leading to callings not already mentioned. The President of the college acts as special vocational counselor for all students.

\section{Student Advisers}

For registration, advice and supervision all students will be assigned to faculty advisers. Each faculty member will have from fifteen to twenty students, making it possible for each student to receive special attention in regard to his course. The adviser directs the student in the arrangement of a course of study in harmony with his tastes or prospective vocation. The aim of this system of advisers is more intensive and consistent courses of study, vocational direction, timely warning to laggards and closer and more friendly cooperation. Assignments to an adviser are made by the Dean of the College, with the purpose of securing to each student that adviser who will be of the greatest service to the student. When students have definitely fixed upon a vocation in life they will be assigned to that member of the faculty whose department is most akin to the work they have in view. Students who have fixed upon their major study will be assigned to the head of the department to which that major study belongs. 


\section{Courses of Study}

\section{Biology}

\section{Professor WALTER}

The courses have been so arranged that it is possible to choose work either of a general or a special nature. Students wishing a well rounded education will be able to select work which will meet their needs and in which the cultural aspect is emphasized. Choices should be made from the following: Biology $1,3,7,8,21$.

Those preparing to teach Biology in high schools will be able to choose suitable work and will be given opportunity for practice in laboratory instruction, grading of papers and note books, and the planning of high school courses. The following courses are suggested for Zoology: Biology 1, 2, 3, 8, 20; for Botany: Biology 20, 21, 22, 23. For work suited to the needs of the pre-medics, the following are recommended: Biology 1, 2, 3, 4, 5 .

\section{General Zoology.-}

This course takes up the fundamental principles of animal biology. Representatives of the phyla of the invertebrates and vertebrates are studied with reference to structure, functions and relation to environment.

One year, two two-hour laboratory periods and two recitations a week, eight credits. This course counts four credits toward a major or minor if the student's grade is " $\mathrm{B}$ " or better.

\section{Comparative Anatomy.-}

Consists of lectures, quizzes, assigned readings, and an intensive laboratory study of the shark, perch, necturus, pigeon and cat.

Prerequisite, course 1. First semester, two three-hour laboratory periods and one recitation a week, three credits.

\section{Human Biology.-}

Lectures, recitations, demonstrations and collateral readings on the structure and functions of the human body. Extensive use is made of anatomical charts and models. Attention is also given to personal hygiene.

Prerequisite, courses 1 and 2 . Second semester, three hours a week, three credits. 


\section{Vertebrate Embryology.-}

A study of the development of the chick and the pig embryos.

Prerequisite, courses 1 and 5 . Second semester, two three-hour laboratory periods and one recitation a week, three credits. Not offered 1923-1924.

\section{Vertebrate Histology.-}

A study of the microscopic structure of the tissues and organs of the body. Special emphasis is placed on training in laboratory technique.

Prerequisite, courses 1 and 2. First semester, two three-hour laboratory periods and one recitation a week, three credits. Not offered 1923-1924.

\section{Genetics and Eugenics.-}

The principles of heredity, as illustrated by plants and animals, as well as the relation of these principles to the betterment of the human race will be studied. The latest edition of "Genetics and Eugenics" by Castle will be used, supplemented by collateral readings in Conklin and Guyer.

Prerequisite, course 1. First semester, two hours a week, tw o credits Not open to Freshmen or Sophomores.

\section{General Bacteriology.-}

This is a course of lectures and recitations suited to the general or special student who desires to have an intelligent idea of the cause and prevention of some of the important diseases.

Prerequisite, courses 1 or 21 . Second semester, two hours a week, two credits.

\section{Individual Course.-}

Advanced students may, with the approval of the head of the department, take up lines of work not covered in the regular courses. Such work will consist of laboratory exercises and assigned readings.

First or second semester, or one year, two or four credits.

\section{0. 'Teachers' Course.-}

For those who intend to teach biology in high schools. Practical work given in the laboratory. Conferences on methods of teaching and reviews of text-books. Credit cannot be given for one semester's work.

Prerequisite, courses 1, 2, 21. One year, four credits.

\section{General Botany.-}

A study of the principles of plant life. The main topics treated are living matter, cellular organization, general structure, physiology and reproduction of the principal groups with an introduction to the methods of identification and classification of plants.

One year, two two-hour laboratory periods and two recitations a week, eight credits. 
22. The Flowering Plants.-

Lectures and recitations on the structure, adaptation and classification of the higher plants. Laboratory work on vascular tissues and flower structure and analysis. In the spring a study will be made of the trees and flowers of the region.

Prerequisite, course 21. Second semester, three credits. Not offered 1923-1924.

23. Cryptogamic Botany.-

This course deals with the lower forms of plant life in their relation to each other. Emphasis is placed upon those forms that are of economic importance, such as bacteria, yeasts and the fungi that cause plant diseases.

Prerequisite, course 22. First semester, three credits. Not offered $1923-1924$

\section{Chemistry \\ Professors JoNes AND THACKER}

\section{General Inorganic Chemistry.-}

The course includes a thoro study of the principal elements and their compounds, their occurrence in nature, preparation in the laboratory, etc.; also an introduction to the study of qualitative analysis.

One year, seven hours a week, eight credits. Six credits will be allowed seniors taking this course.

This course counts four credits toward a major or minor if the student's grade is $\mathrm{B}$ or better.

2. Advanced Inorganic Chemistry.-

This is a continuation of course 1 , with an introduction to physical chemistry.

Prerequisite, course 1. One year, six hours a week, six credits.

3. Qualitative Analysis.-

Lecture and laboratory work, including the detection and separation of the metals and the identification of the acids The last few weeks of the year are spent in the analysis of specimens of rock and earth. Instead of this the student may make a study of materials used as paint pigments and the methods used in paint analysis.

Prerequisite, course 1. One year six or eight hours a week, four or six credits; or second semester, twelve hours a week, six credits.

\section{Quantitative Analysis.-}

Lecture and laboratory work. This includes an introduction to the gravimetric and volumetric analysis and a study of the methods of determination of atomic weights.

Prerequisite, courses 1 and 3 . One year, six or eight hours a week six or eight credits.

A combination course of 3 and 4 may be arranged with a total of eight credits. 


\section{Organic Chemistry.-}

A course of lectures on organic chemistry, including a study of the aliphatic and aromatic compounds. The chemistry of foods, oils, explosives, etc., is considered. Some of the important compounds are prepared before the class. A laboratory fee of one dollar is charged, except when course 6 is also taken.

Prerequisite, course 1 . One year, three hours a week, four credits.

\section{Laboratory Course in Organic Chemistry.-}

To be taken with or upon completion of course 5. Organic compounds are prepared and studied. Quantitative results are expected. This course should be taken with course 5 , when possible.

One year, six hours a week, four credits.

7. Advanced Organic Chemistry and Qualitative Organic Analysis.-

This course is a continuation of courses 5 and 6 . The detection of common food adulterants will receive attention. six credits.

Prerequisite, courses $1,2,3,5$ and 6 . One year, six hours a week,

\section{Food Analysis.-}

Milk and butter analyses receive special attention.

Prerequisite, courses 1,3 and 4 . One year, six hours a week, four credits, or one semester, twelve hours a week, four credits.

9. Water Analysis.-

Prerequisite, courses 1,3 and 4 . One semester, six hours a week three credits.

\section{Teachers' Course.-}

This course is designed for those who intend to teach chemistry. They are given practical work in the laboratories, instructing students beginning chemistry, preparing solutions, etc. A course of lectures is given on the teaching of chemistry.

Prerequisite, courses 1 and 3 . One year, three or six hours a week two or four credits. No fee is charged.

Credits not counted toward a major or minor.

\section{Chemistry of Foods.-}

A lecture course on foods, their sources, values and conservation.

Second semester, two hours a week, two credits. 


\section{Education}

\section{PROFESSOR ANDERSON}

\section{Principles of Teaching.-}

A course in teaching for prospective teachers in secondary schools. The course includes the physical and mental characteristics of the adolescent pupil; the cultivation of proper methods of study on the part of the pupil; the general methods of teach. ing with illustrative applications. Each student in this class must present, not later than February the first, a complete set of plans for ten consecutive lessons in an approved subject.

Prerequisite, twenty-fo'dr credits. First semester, three hours a week, three credits. Students taking this course are advised to register at the same time for Philosophy 1, unless they have already obtained credit in that course. Required for faculty recommendation for teaching.

2. Administration and Management.-

This course opens with a preliminary sketch of the origin of our school system. Then follows a study of the organization and administration of our schools. Attention will be given in particular to the secondary school system. The course concludes with a discussion of the problems of class management.

Prerequisite, twenty-four credits. Second semester, three hours a week, three credits.

3. History of Education.-

A general course in the history of education. It includes ancient oriental education, education in Greece and Rome and through the medieval times. A fuller treatment is accorded the educational movements from the Renaissance to the present. Students taking this course are advised to take a course in European history, if they have not already done so.

Prerequisite, twenty-four credits. First semester, three hours a week three credits. Not offered 1923-1924.

4. Present Systems and the Philosophy of Education.-

This course takes up the work where the previous course leaves off, with a study of modern educational systems. The study of the modern systems is used as a basis for a consideration of the aims of education immediate and remote.

Prerequisite, course 3 . Second semester, three hours a week, three credits. Not offered 1923-1924.

Credit in the Department of Education is given also for the following courses:

Biology 20

Chemistry 10

English 11

French 7

German 11

History $10,11,16$
Latin 16

Mathematics 7

Mental Science and Philosophy 1, 4

Music 6

Physics 5

Religious Education 8

Social and Political Science 44

The work in practice teaching is given in connection with the courses in teaching in the various departments and is in the care of the heads of those departments. 


\section{English}

Professors Johnson, Clark, Whitridge and Doty AND Miss GuILFORD

This department offers a major in English Literature and a minor in Expression or English Composition. Courses offered as English Composition may be counted toward a major in English Literature.

\section{Composition and Public Speaking}

1. Composition.ANd Miss GuILFoRd

Professors Clark and Doty

This course is required of all freshmen. Its purpose is to give the student practice in speaking and writing and to lay a foundation for future work in English.

One year, three hours a week, six credits.

2. Expository Writing.-

Professor Clark Attention will be given to the organization and presentation of material, but the chief emphasis will be placed upon the development of the sources of originality of the student himself. The best work will be published in the Gateway Magazine. Second semester, two hours a week, two credits.

3. Short Story Writing.- -

Professor Clark

This course is designed for those who wish to attempt advanced work in narrative writing. The best stories written in this course will be published in the Gateway Magazine.

First semester, two hours a week, two credits.

4. Newspaper Writing.-

Professor Clark

(a) Introductory Course-This course introduces beginners to the theory and practice of journalism. Students wishing appointment to the Mac Weekly staff are advised to register for this course.

First semester, one credit.

(b) Advanced course.

Prerequisite, course 1. Second semester, one credit.

5. Seminar in Advanced Composition.- Professor Clark This course is designed for those who have done or wish to do some original writing outside of the regular class room work. No student should enroll for this course until he has consulted the instructor. credit.

Prerequisite, fifty-four credits. One semester, one hour a week, one

6. Play Writing.-

Professors Clark and Whitridge First semester, three hours a week, three credits.

7. Public Speaking.-

PROFESSOR. Clark

The object of this course is to correct a student's faults in public speaking and enable him to present a message effectively from the platform.

First semester, two hours a week, two credits. 
8. Argumentation and Debate.-

Professor Clark A study and analysis of great debates by Calhoun, Webster, Lincoln and others. Abundance of practice is given in drawing up of briefs and in actual debating.

Prerequisite, twenty-four credits. Second semester, two hours a week, two credits.

9. Extemporaneous Speaking.- Professor Clark

Registration for this course is limited to eight students. An entrance is based upon competitive tests.

Prerequisite, twenty-four credits. Second semester, two hours a week, two credits.

10. Seminar in Debating and Oratory.-

Professors Clark and Hazzard

Open to those who represent the college in intercollegiate debates and in the state oratorical contest.

One semester, two hours a week, two credits.

11. Teachers' Course.-

Professor Clark

This course is designed to prepare students to teach English in secondary schools. The work consists of lectures, reports and actual practice teaching.

First semester, three hours a wcek, three credits.

13. English Philology.-

Professor Clark

Second semester, two hours a week, two credits.

15. World Masterpieces.-

Professor Clark The course consists of an intensive study of the Book of Job, Homer's Odyssey, Dante's Inferno, Shakespeare's Othello, and Goethe's Faust. credits.

Prerequisite, 54 credits. First semester, three hours a week, three

2. English Language and Literature PROFESSOR JOHNSON

22. American Literature.-

Lectures and critical reading of selected authors; themes on assigned reading.

Prerequisite, course 1. One year, three hours a week, six credits.

23. Old English.-

A study of the language, and reading of selections from the Old English Chronicle, King Alfred, Aelfric and the simpler poetry; Beowulf.

Prerequisite, course 1. One year, three hours a week, six credits Not offered 1923-1924. 


\section{English Literature.-}

The aim of this course is to emphasize the main facts in the development of English literature from the seventh century until about 1600 . Chaucer and Spenser are extensively read and discussed.

Prerequisite, course 1. One year, three hours a week, six credits.

25. English Literature.-

Shakespeare and Milton.

One year, three hours a week, six credits. Not offered 1923-1924.

26. The Drama in England.-

Special attention will be given to the writings of the minor dramatists of the Elizabethan period. While the course deals chiefly with the English drama, attention will be given to other literatures.

Prerequisite, courses 1,24 and 25. One year, three hours a week, six credits. Not offered 1923-1924.

27. History of Literary Criticism.-

A study of the principles governing literary composition.

Prerequisite, courses 1 and 24. First semester, three hours a week, three credits.

28. Browning and Tennyson.-

A comparative study.

Prerequisite, courses 1, 24 and 27. Second semester, three hours a week, three credits.

29. The English Novel.-

Its rise and development.

Prerequisite, courses 1 and 24 . One year, three hours a week, six credits. Alternate for course 26.

Any of the above courses may be elected by the semester.

\section{Expression}

\section{Adjunct Professor Whitridge}

\section{Elocution and Voice Training.-}

1. Theory. The principles underlying the art of expression and literary interpretation.

2. Practice. Deep breathing. Correction of voice faults and mannerisms. Factors of expression. Analysis and interpretation of the classics. Reading and speaking.

One year, three hours a week, four credits.

2. Literary and Dramatic Interpretation.-

Pantomime. Adaptation of the short story and play for platform work. Story telling. Scenes and original presentations,

Prerequisite, course 1. One year, two hours a week, four credits. 
3. Shakespeare and Modern Drama.-

Analysis and presentation. credits.

Prerequisite, courses 1 and 2. One year, two hours a week, four

\section{French}

\section{Professors Anderson and Kellogg}

\section{1-2. Elementary French.-}

Essentials of grammar, conversation, reading of easy texts, memorization of a few short poems, and dictation. This course is intended for those who have had no French.

One year, four hours a week, eight credits.

3. French Readings.-

Brief review of French grammar. Composition, conversation, and the reading of a number of nineteenth century French texts.

Prerequisite, course 1-2 or two years of high school French. One year, three hours a week, six credits.

4. Survey of French Literature.-

A course based on some elementary history of French literature like Pellissier's or Doumic's, with readings of extracts and a few entire works from the most important French writers. Lectures, outside readings, and reports.

Prerequisite, course 3 or an equivalent. One year, three hours a week, six credits.

\section{French Novel.-}

A brief survey of French fiction from the beginning, and special attention to French romances and novels from the seventeenth century on. Text used, Morrillot's Le Roman en France. Lectures, outside readings, reports.

Prerequisite, course 4. One year, three hours a week, six credits. Not offered 1923-1924.

6. French Drama.-

A course based on Petit de Julleville's Le Theatre en France. Lectures, outside readings, reports.

Prerequisite, course 4. One year, three hours a week, six credits. Not offered 1923-1924.

\section{Teachers' Course.-}

Phonetics, advanced grammar, practical composition and conversation. Discussion of texts, reference books, journals, etc., and methods of teaching. Required of all who wish to teach French; optional with others. This course should be taken in the senior year.

One year, three hours a week, six credits. 


\section{French Poetry.-}

A study of prominent works of important French poets, and of French songs, combined with a brief treatment of French verse structure. Lectures, readings, reports.

Prerequisite, course 3 or an equivalent. One year, three hours a weck. six credits. Not offered 1923-1924.

9. French Classics.-

Study and discussion of masterpieces of French literature from the seventeenth century on, of one or more writers of each century. Lectures, readings, reports.

Prerequisite, course 4 or an equivalent. One year, three hours a week, six credits.

11. Scientific French.-

Readings from general scientific works intended to fit students of the sciences for research work in their special science.

Prerequisite, course 3 or an equivalent. First semester, four hours a week, four credits.

12. French Composition.-

This course furnishes abundant practice in both composition and conversation.

Prerequisite, French 3 or an equivalent. Second semester, three hours a week, three credits.

A major in French requires continuous work in the language thruout the college course, unless French is presented upon entrance. It is highly desirable that Latin be presented as a basis for French.

\section{Geology \\ Professor ALEXANDER}

1. General.-

A general study of the forces at work within and upon the surface of the earth, the structural forms which these forces have produced and the history of the earth and the life upon it. Illustrated lectures combined with recitations and quizzes upon text work assigned. Field work for the study of local geology.

One year, three hours a week, six credits.

2. Mineralogy.-

A short course in mineralogy including a brief study of crystal forms and practical methods for the identification of the common minerals.

Prerequisite, Chemistry 1. First semester, three hours a week, three credits.

3. Fossil Biology.-

A short course in fossil biology. This includes a study of the methods used for collecting, identifying and interpreting fossil forms and their life relationship.

Prerequisite, elementary biology or geology 1 . Second semester, three hours a week, three credits. 


\section{German}

\section{Professor Chalfant and Mr. Grosshuesch}

\section{1-2. Elementary German.-}

Essentials of grammar, reading, conversation. This course is intended for students who have had no German.

One year, five hours a week, ten credits.

3. Intermediate German.-

Reading. of prose and the easier dramas of Schiller and Lessing. Review of grammar; composition; conversation.

Prerequisite, course 1-2 or two years of high school German. One year, four hours a week, eight credits.

4. Modern Prose and Drama.-

General reading course.

Prerequisite, courses 1-2 and 3 if the language was begun in college. Those presenting three years of high school German may either elect this course or one of courses $5,6,7,12$. One year, three hours a week, six credits.

5. Reading of selections from the epic in a modern German translation, followed by a rapid reading of Wagner's Der Ring der Nibelungen. Lectures on the interpretation of the mythology of both.

Second semester, three hours a week, three credits.

6. Survey of German Literature.-

A general survey course up to the classic period; readings and reports.

One semester, three hours a week, three credits.

7. Lessing.-

A briet study of his life and times and the reading of at least two of his important works.

First semester, three hours a week, three credits.

8. Schiller.-

A rapid survey of his life and the reading of several of his dramas and his most important poems.

Second semester, three hours a week, three credits.

11. Composition and Teachers' Course.-

Advanced syntax and practical composition; conversation. In the second semester a sufficient amount of time will be devoted to methods of teaching, text books, phonetics, etc. Required of all those who desire to teach German; with others optional.

One year, three hours a week, six credits. Senior year preferred.

13. Medical German.-

Readings from general works on physiology, anatomy and bacteriology.

One year, three hours a week, six credits. 


\section{Greek \\ Professor Hall}

Course 1 is not counted toward a major.

\section{Grammar.-}

A study of the elements of the language. Drill in form, vocabulary, syntax and composition. Readings from Xenophon's Anabasis.

One year, five hours a week, ten credits.

2. Xenophon or Lucian and Homer.-

(a) The Hellenica, Books I and II, with discussion of the earlier stages of the Peloponnesian war or Lucian's Charon or Timon and selected short dialogues, with a survey of the literary and social conditions of the age.

(b) The Iliad, Books I-IV in literary and grammatical study. Prerequisite, course 1. One year, four hours a week, eight credits.

3. Athenian Orators.-

Selected orations of Lysias and Demosthenes. Theme work on Isaeus, Isocrates and others. Athenian legal procedure. credits.

Prerequisite, course 2. First semester, three hours a week, three

4. Plato.-

The Apology and Crito. Socrates and his teachings, with readings from Xenophon's Memorabilia. credits.

Prerequisite, course 2. Second semester, three hours a week, three

\section{The Drama.-}

Selected plays of Aeschylus or Euripides and Aristophanes. Rise and development of tragedy and comedy. The Greek theater and production of plays.

Prerequisite, courses 1, 2, 3 and 4. First semester, three hours a week, three credits.

\section{English Course in Greek Literature.-}

Studies in the elegiac, lyric and dramatic poets of Greece for students having no knowledge of Greek.

Prerequisite, twenty-four credits. First semester, two hours a week, two credits. 


\section{The Odyssey.-}

Selections from Books I-XII. Sight reading. Literary study of the whole poem from the English translations of Palmer and of Butcher and Lang.

Prerequisite, courses $1,2,3$ and 4. Second semester, three hours a week, three credits.

8. Lyric Poetry.-

Selections from the elegiac and lyric poets.

Prerequisite, courses $1,2,3$ and 4 . Second semester, two hours a week, two credits.

9. The Greek Testament.-

This course is intended not only for candidates for the ministry but for any who have studied classical Greek and who wish to acquire a reading knowledge of the New Testament in the original Greek. The aim is to master a good working vocabulary, the main characteristics of New Testament Greek and to get some practice in Greek exegesis.

Prerequisite, Greek 1. One year, four hours a week, eight credits.

10. Classic Mythology.-

A study of the more important myths of Greece and Rome with special attention to their use in English literature.

Second semester, two hours a week, two credits.

\section{History}

Professors Funk and McRae, Mr. Berryman and Miss Briggs

Students who major in this department ordinarily will be required to take courses $1,2,5$ and 6 . Courses 1,5 and 6 are open to freshmen. Students choosing history as a minor are recommended to pursue courses 5, 6 and 9. Those majoring in this department will be expected to secure at least eighteen credits in related subjects, such as economics, sociology, political science, and the history of philosophy.

\section{Early European History and the Middle Ages.-}

Mr. BERRYMAN

This course covers a resume' of Roman imperial institutions society and culture, the origin and racial characteristics of European peoples, the beginnings and growth of the church and extends to about 1450 . Lectures, text, collateral reading form the basis of the work.

One year, three hours a week, six credits. 


\section{English Political and Constitutional History.-}

Professor McRae and Mr. Berryman This is a study of the political and constitutional development of England to 1660 . Some attention will likewise be paid to social and economic development.

One year, three hours a week, six credits.

3. The Renaissance and the

Reformation.-

Professor Funk

This course covers the period from 1300 to 1648 . The greater part of the first semester is devoted to the Renaissance and the remainder of the year is given to the Reformation. Topical reports and a thesis are required.

One year, three hours a week, six credits.

4. The French Revolution.-

PROFESSOR FUNK

In this course the causes bringing about the fall of the Bourbons, the revolution proper and the Napoleonic era are studied.

First semester, three hours a week, three credits.

5. American History.-

PROFESSOR FunK 1787-1850. This course is a study of the making of the constitution, the organization of the government, formation of political parties, economic and territorial expansion and the growth of national consciousness and power. Text-book, lectures and collateral reading.

First semester, three hours a week, three credits.

6. American History.-

PROFESSOR FUNK 1850-1918. In this course are studied the forces which brot about the division and reunion of the nation, the period of reconstruction, and those economic, social and political events that have characterized our recent history. This is a continuation of History 5 .

Second semester, three hours a week, three credits.

\section{American Colonial History.-}

Beginning with a background study of European conditions leading to the discovery of America, the voyages and explorations, the settlements in the colonies, this course aims to trace the development of those institutions and forces which led to American independence, and ends with a careful study of the Revolution.

Second semester, three hours a week, three credits. 
8. The Westward Movement.-

Professor FunK This is a study of the westward extension of the United States and of the economic and political development resulting from this expansion.

Prerequisite, course 7, or courses 5 and 6 . First semester, three hours a week, three credits. Not offered 1923-1924.

9. Modern European History.-

PROFESSOR FunK From 1815 to the present time. Special attention is devoted to the establishment of constitutional governments and the industrial evolution of this period.

One year, three hours a week, six credits.

10. History of Rome.-

A systematic study of the social and political development of the Roman nation and the causes of its downfall. Course will consist of text-book work, collateral reading and lectures. Recommended to those intending to teach Latin and History.

One year, three hours a week, six credits.

11. History of Greece.-

A study of the political and social development of the Greek states to the time of their incorporation into the Roman Empire. Special attention will be given to the permanent influence of Greek civilization. Text-book work, reading, lectures.

One year, three hours a week, six credits.

12. History of Fine Arts.-

Miss BRIGgs

A study of the development of architecture, sculpture and painting thru the various periods of ancient, medieval and modern art. An effort is made to familiarize the student with the great masterpieces by means of photographs, stereopticon lectures and visits to the art galleries in St. Paul and Minneapolis.

One year, two hours a week, four credits.

13. History of American Diplomacy.- Professor Funk This is a chronological survey of the relation of the United States to foreign countries from 1776 to the present time. Text-book, lectures and collateral reading. 1924.

Second semester, three hours a week, three credits. Not offered 1923- 
15. English, Social and Political History from 1660 to the Present.-

PROFESSOR MCRAe

Special attention will be paid to the development of the cabinet and parliamentary system and the expansion of English world policies.

Second semester, three hours a week, three credits.

16. Historical Method.-

PROFESSOR FunK

This course is a study of the history of history, the development of a scientific historical method. When taken in conjunction with History 10 or 11 it gives six credits in Education.

One year, three hours a week, six credits.

3. The House.-

\section{Home Making \\ PROFESSOR WHITRIDGE}

(a) Evolution of the modern home from primitive conditions. Its object. Selection of site with regard to climate, soil, drainage and neighborhood. Location of house with regard to exposure, light and prevailing winds. Study of house plans to meet the requirements, comfort and convenience of the family for which the house is intended. Drawing of specific plans.

(b) Household Art.-

Furnishing the house from the standpoint of good taste and economy. Value of form, color, design and materials in interior decorations. Wallpapers, carpets and curtains. History of furniture. Household management.

First semester, three hours a week, three credits.

\section{Social Culture.-}

The hospitality of the home. The forms and customs known and observed in community life.

Second semester, one hour a week, one credit.

\section{Latin \\ Professor Hazzard}

Courses 1-2 and 17 are open without prerequisites to all students. Students who have had less than two years of Latin in high school should enter course 1-2; those who have had two or three years should enter course 3-4; those who have had four years should enter either course 5 or course 7 . Courses 5 and 6 may be taken either before or after courses 7 and 8 . Students who desire to be recommended by the department to teach Latin are required to have had courses 5 to 10 inclusive and 16 and are strongly urged to take course 15. Courses 1-2 and 3-4 are not counted toward a major. 


\section{1-2. Elementary Latin.-}

The content of this course corresponds to that of the first two years of high-school Latin. Elements of grammar; easy readings; selections from Caesar.

One year, five hours a week, ten credits.

\section{3-4. Intermediate Latin.-}

The content of this course corresponds to that of the third and fourth years of high-school Latin. The choice of selections to be read is made with a view to the previous reading of the members of the class.

Prerequisite, two years of high-school Latin or course 1-2. One year, four hours a week, eight credits.

5. Livy.-

Selections from Livy's account of the Second Punic War. Review of forms and syntax.

Prerequisite, four years of high-school Latin or course 3-4. First semester, four hours a week, four credits. Not offered 1923-1924.

6. Comedy.-

Representative plays of Plautus and Terence. Collateral work on the history of the drama and the Roman theatre.

Prerequisite, course 5 . Second semester, four hours a week, four credits. Not offered 1923-1924.

\section{Cicero.-}

Readings from Cicero's essays and philosophical works. Review of forms and syntax.

Prerequisite, four years of high-school Latin or course 3-4. First semester, four hours a week, four credits.

8. Horace.-

Selections from the whole of Horace's works. Special attention is paid to literary criticism and appreciation.

Prerequisite, course 7. Second semester, four hours a week, four credits.

\section{9-10. Prose Composition and Sight Reading.-}

Should be taken with courses 5 and 6 or 7 and 8 . One year, one hour a week, two credits.

\section{Poets of the Republic.-}

Study of the poets of the republican period with reading of extensive selections from Catullus and Lucretius.

Prerequisite, courses $5,6,7$ and 8 . First semester, three hours a week, three credits. Not offered 1923-1924.

14. Writers of the Silver Age.-

Study of the literature of the Silver Age with reading of selections from the more important authors, especially Tacitus and Pliny the Younger.

Prerequisite, courses 5,6,7 and 8 . Second semester, three hours a week, three credits. Not offered 1923-1924. 
15. History of Latin Literature.-

Lectures on the lives and writings of the important Latin authors, with extensive collateral reading in their works.

First semester, one hour a week, one credit.

16. Teachers' Course.-

Consideration of problems pertaining to the teaching of highschool Latin. The course is conducted by means of lectures and collateral reading.

Prerequisite, courses 5, 6, 7 and 8 . Second semester, three hours a week, three credits.

17. Roman Civilization and Its Survivals in the Modern World.-

Illustrated lectures on the geography of the Roman world, the topography of Rome, Roman architecture, art, commerce, political institutions, law and religion, and the influence of these phases of Roman life on modern civilization. No knowledge of Latin is required.

First semester, two hours a week, two credits.

18. Roman Pastoral Poetry.-

A study of the pastoral poetry of Rome and its relation to English pastoral poetry. Vergil's Eclogues and Georgics will be read.

Prerequisite, courses 5 and 6 or 7 and 8 . Second semester, three hours a week, three credits.

\section{Mathematics and Astronomy}

Professor Kingery

Courses 1 and 9 are not counted toward a major or minor. Course 5 required for a major.

1. Solid Geometry and Algebra.-

This course is for those who present only two units in highschool mathematics.

One year, four hours a week, eight credits.

2. Analysis.-

A course in College Algebra, Trigonometry and Analytic Geometry. Methods of calculus are introduced.

One year, four hours a week, eight credits. 


\section{Analytic Geometry.-}

This is a continuation of course 2. Equations of straight lines and the principal curves and their tangents are discussed by both rectilinear and polar coordinates.

Prerequisite, course 2. First semester, four hours a week, four credits.

4. Differential and Integral Calculus.-

A brief study of the principles of differential calculus based on theory of limits, followed by a short course in integral calculus.

Prerequisite, course 3. Second semester, four hours a week, four credits.

5. Advanced Calculus.-

Continuation of course 4 .

One year, three hours a week, six credits.

6. Surveying.-

Prerequisite, course 2. One or two semesters, three hours a weck, three or five credits.

7. Advanced Algebra and Geometry.-

Intended especially for those preparing to teach.

Prerequisite, course 1. One year, three hours a week, six credits.

8. Astronomy.-

Text-book, lectures and practical work with sextant, transit and clock.

Prerequisite, course 2. One year, five hours a week, six credits.

9. Mechanical Drawing.-

A course designed for those taking shop work or preparing for technical schools.

One, two or three semesters, four hours a week, one, two or three credits.

11. Mathematics of Investment.-

One year, two hours a week, four credits.

\section{The Mental Sciences and Philosophy}

Professors ANDERson and LORENZEN

\section{Psychology.-}

An introductory course covering the main features of normal human psychology:

(1) A brief introduction in experimental work, intended to accustom the student to introspective study and to give him an insight into the methods of modern psychological investigation. 
(2) A survey of the more prominent aspects of the conscious life. This part opens with a synopsis of the nervous mechanism and is followed by a consideration of the sensations, perceptions, affections, memories, judgments, etc. Required for graduation in all courses. Not open to freshmen unless planning to major in Group II.

Either semester, three hours a week, three credits.

\section{Ethics.-}

This course includes an historical sketch of ethical theories and of the conceptions of life that have been held, a study of ethical theory and of practical problems.

The attempt is made in this course to develop a system of thought that does justice to Christian motive and doctrine and is, at the same time, based upon a proper scientific and philosophical basis. Required for graduation in all courses.

Prerequisite, twenty-four credits or course 1. Either semester, three hours a week, three credits.

\section{Logic and Scientific Method.-}

This is a study of the instruments of thought and investigation and of the methods and tests of proof. Much attention is given to fallacies and the analysis of fallacious reasoning. Students may begin this course either semester, but no credit is allowed for one semester.

One year, two hours a week, one of which is used as a laboratory hour, three credits.

\section{Advanced Psychology.-}

The first part of this course requires a more thoro survey of the ground covered in course 1 . The second part is a brief study of social and child psychology. This prepares the way for the third part of the course, the application of psychology to the problems of the day, chiefly those of education.

Prerequisite, course 1. One year, three hours a week, six credits.

\section{Advanced Logic and Scientific Method.-}

A course covering the same general ground as course 2, but much more thoroly. It consists of two parts:-

(1) Formal logic, with a closer study of logical theory and concepts, modal propositions, etc. With it will be given a brief course of lectures on genetic logic. 
(2) Scientific method. A more complete study of the methods of science, including statistics, probability, etc. As a part of this course will be included a brief course of lectures on the history of science.

Prerequisite, course 3. One year, two hours a week, four credits.

Philosophy seeks a consistent view of the world and of life; it seeks the meaning to life and reality; it is cultural in character; it would correct the one-sidedness of the mere specialist and correlate the results of general study. Students may begin with any of the following courses:

\section{History of Philosophy, Ancient and Medieval.-}

Beginning with the early Greeks this course follows the course of philosophic thought down to the period of Bruno, with the purpose of noting the development and relationships of the chief philosophical concepts. Attention is concentrated upon the leading thinkers and on the movement of thought. Collateral readings in Plato, Aristotle and others are required.

Prerequisite, fifty-four credits, unless by the approval of the Instructor. First semester, three hours, three credits.

\section{History of Philosophy, Modern.-}

Continuing the preceding, from Bruno to the present time. Constant use of Rand's classical Modern Philosophers is made for collateral reading.

Prerequisite, seventy credits, unless by the approval of the Instructor. Second semester, three hours, three credits.

\section{2-13. English Thinkers.-}

The course deals with the characteristics of English thought and some of the important English philosophical movements. It will include readings in representative philosophers. Each student in the course will be expected to make an intensive study of some one thinker.

Prerequisite, fifty-four credits, unless by the approval of the instructor. The course may be elected for either or both semesters, three hours a week, three or six credits. Not offered 1923-1924.

\section{Music}

Mr. Phillips, Mr. Fairclough, Miss Kay, Miss Briggs and Miss Ýoung

Music may be chosen as a major or minor. The maximum number of credits permitted in such work is thirty-two. Not more than eight credits in practical music (voice, organ, piano, violin) will be allowed upon recommendation of the faculty of the Conservatory of Music after a sufficient amount of harmony (usually two years) has been completed. Of the twenty credits required for 
a major eight credits in harmony and two in Physics 6 must be obtained. Of the twelve credits required for a minor six must be obtained in theoretical music, and of these two in harmony and two in appreciation are required.

The special fees for courses in music must be paid by the student at conservatory office, except in courses $1,7,9$ and 10 .

\section{Elementary Harmony.-}

The work of this year will include all triads, seventh chords, cadences, modulation and suspensions.

One year, two hours a week, four credits.

\section{Advanced Harmony.-}

This is a continuation of the first year's study for greater proficiency in the use of the material. The student will compose and have a great deal of practice in transposing pieces heard but once. Memorizing will be an important feature of the work.

One year, two hours a week, four credits.

\section{Counterpoint.-}

Simple counterpoint beginning with two, three and four-part writing in one, two, three and four notes against one is studied first, followed by syncopated and florid counterpoint with special stress on the latter used in three and four parts.

First semester, two hours a week. two credits.

\section{Elementary Composition.-}

This course is an introduction to the art of composition, with original work in the simpler forms, instrumental and vocal. Facility and clearness in the use of original musical ideas expressed through modern harmony and counterpoint are sought. The student is expected to accomplish work of sufficient merit for public performance.

Second semester, two hours a week, two credits.

\section{Composition and Orchestration.-}

A course in original composition. Instrumental and vocal compositions of simple and complex forms: (a) In the strict classical forms from song to sonata in homophonic and polyphonic style; (b) In the free forms, applying modern means of harmonization, modulation and imitation; (c) Orchestration. This work must have sufficient merit for public performance.

One year, two hours a week, four credits. 


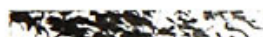

6.

\section{\& S mury}

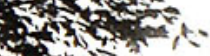

tistion

Nis.

iser 3

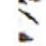

ice

tixese

nis

4ini

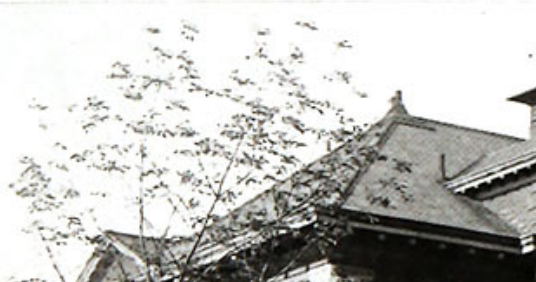

2

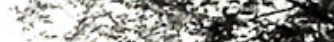

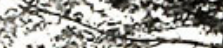

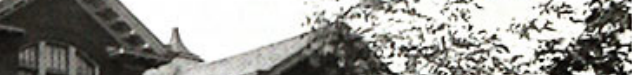
III 2 an af

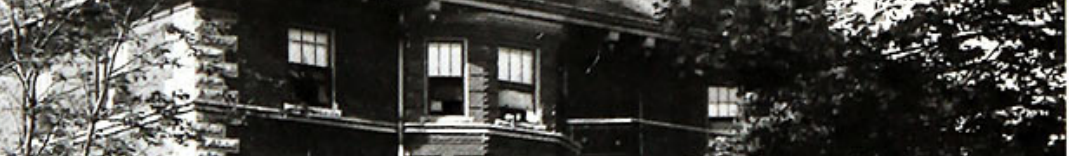
(1) 1 .

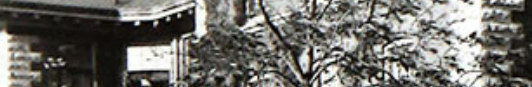

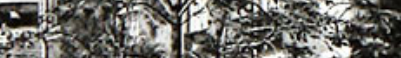

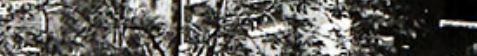

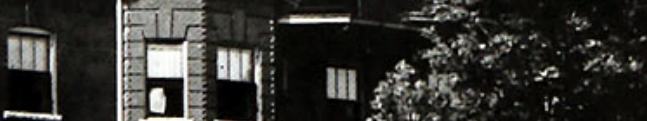

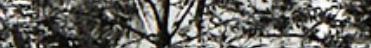

-3 .

2019

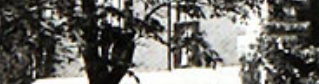

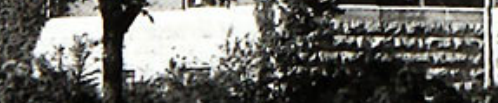

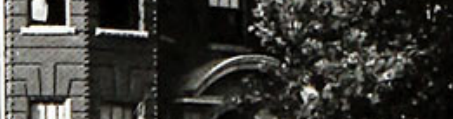

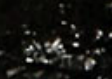

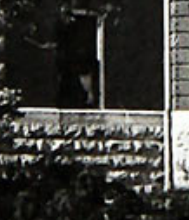

1)

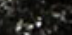

cis

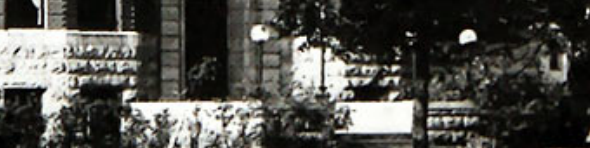





\section{Public School Music.-}

For a detailed description of this course see Conservatory of Music.

Two years, two hours a week, eight credits.

\section{History of Music.-}

A study of the beginnings of music through the classical period. including the history and development of instruments. The college library has a good collection of reference works on music and our students have access to the fine collections in the public libraries of the Twin Cities.

One year, two hours a week, four credits.

\section{History of Music.-}

This is a continuation of Course 7, studying the development of music from the Romantic period to our own day. By means of the talking machine, records of many operas, oratorios, symphonies, songs and piano compositions are studied.

One year, two hours a week, four credits.

\section{Appreciation of Music.-}

This is a study of the form and meaning of music. A preliminary study of the instruments of the orchestra is given preparatory to the concerts of the Minneapolis Symphony Orchestra.

One year, two hours a week, four credits.

10. Appreciation of Music.-

This is a continuation of Course 9 and is devoted to a thorough study of romantic and modern forms since the time of Beethoven.

One year, two hours a week, four credits.

11. Normal Training for Piano Teachers.-

(a) Course for advanced and senior students, who, tho good performers, are not prepared for the art of teaching.

(b) Course for young teachers requiring a more complete knowledge of modern piano teaching methods and material. See Conservatory of Music for further details.

One year, two hours a week, four credits.

12. Junior Progressive Series Theory....

One year, one hour a week, two credits.

13. Senior Progressive Series Theory.--

One year, one hour a week, two credits. 


\section{Physics}

\section{Professor Alexander}

Course 1 is not counted toward a major.

\section{General Physics.-}

This is a short course which covers the entire subject in one year. Demonstrations in connection with the lectures are substituted for a considerable amount of the individual laboratory work that is done by the student in the long course, and some of the more technical features of the subject that are not of general importance are omitted. The aim is to offer a thoro year's work in the general principles of physics to those who are taking courses which will not permit them to take the regular long course in the subject. It is recommended only to those who are taking classical or literary courses, or a two-year course in preparation for some school of medicine. Students entering this course without credits of one unit high school physics are required to do supplementary work under a tutor.

Prerequisite, Mathematics, course 2. One year, six hours a week, eight credits.

\section{Mechanics, Sound, Heat.-}

This course includes a thoro study of mechanics, sound and heat. A large part of the time is spent in laboratory work and the student's conceptions of physical laws are developed as largely as possible from observation and experiment. About forty quantitative experiments are performed by each student in the laboratory, the aim being to afford a working knowledge of modern measuring instruments of precision and to develop quantitative methods, as well as to discover and verify the laws of nature. Careful attention is given to the problem of the errors in measurement, the student being required in each case to consider the origin of the errors and methods for their elimination and to compute the probable errors of observations and results.

Prerequisite, Mathematics, courses 1 and 2 . One year, six hours a week, eight credits. Not offered 1923-1924. 


\section{Electricity and Light.-}

This course includes a thoro study of electricity and light. Forty experiments are performed, thirty-five of which are in electricity, giving the student an opportunity to familiarize himself with electrical measuring instruments. The work in light includes measurements with the photometer, spectrometer and interferometer.

Prerequisite, Mathematics, course 2. One year, six hours a week, eight credits.

Courses 2 and 3 together constitute what is termed the long course in physics and are designed especially to meet the needs of students taking a scientific course. These two courses together with Physics 5 should be taken by students preparing to teach physics in secondary schools.

\section{Advanced Physics.-}

In this course a thoro study is made of some topic approved by the head of the department. The work is largely individual and experimental. The aim is to deepen rather than to broaden the student's knowledge of the subject and to cultivate a taste for research. Those who major in physics are required to take this course as a basis for their theses. credits.

Prerequisite, course 2 or 3 . First semester, four hours a week, two

\section{Laboratory Technic.-}

In this course a study is made of the design, construction, operation and repair of the more elementary laboratory apparatus and of the use and manipulation of laboratory materials. The aim is to afford those students who are preparing to teach physics a practical working knowledge of the physical laboratory. two credits.

Prerequisite, course 1,2 or 3 . Second semester, four hours a week.

\section{Sound.-}

This course includes a study of the mechanics of sound, particularly wave motion, interference, resonance and quality. Also the development of the diatonic and tempered scales and the construction and theory of the common musical instruments.

One semester, three hours a week, two credits. 


\section{Religious Education}

\section{Bible Training}

\section{On the John C. Martin Foundation}

Professors Wallace and McRae and Miss Gunnison

The great importance of moral and religious training finds, in all our colleges, increasing recognition. Intellectualism alone has proved utterly inadequate for the individual, society and the nation. Knowledge and efficiency cannot safely be made the ultimate aim of education. A much more vital and important consideration is, what are the ends which knowledge and efficiency must be made to serve.

In any complete system of education the spiritual nature of man and his chief end in life must be amply recognized. The best known means for the cultivation of this nature and for the discovery of this chief end is found in Christianity, in the central figure of all history-Jesus Christ.

Every educated man and woman should have, must have, a true philosophy of life and we believe that such philosophy is found in the Christian view of God and of the world as presented in the Holy Scriptures.

For the above reasons Macalester has made large provision for religious training.

In addition to the required courses for all students the department offers elective and advanced courses for students wishing (1) prepare themselves for forms of Christian service other than the gospel ministry.

The church, as well as the world, has entered on the era of the laity. Christianity is girding itself for the conquest of the world. Her call for leaders and workers of all sorts is louder and more engaging than ever before. The world is white unto the harvest and the reapers include not only preachers and evangelists, but missionary teachers, missionary physicians, settlement workers, pastors' assistants, secretaries of Young Men's and Young Women's Christian Associations, trained Sunday school organizers, and lay workers generally.

To students training for any of these vocations the college offers special advantages. Open to them is instruction in many 
subjects essential to thoro preparation for any of the above forms of Christian activity, such as languages, science, literature, philosophy, history, ethics, sociology, elocution, music.

Courses 1 , one semester, and 2 are not counted toward a major or minor.

1. The Life of Christ.-

Professor Wallace

(a) This is studied by means of a harmony of the gospels. By way of introduction attention is directed to the political and religious condition of the time and to the characteristics and view-point of the gospel writers. By discriminating discussion of the teachings of Christ and a realistic presentation of the facts and incidents of His life an effort is made to deepen personal faith in Christ as the Savior of men and to bring the student into appreciation of Jesus as the master teacher of all time. Attention is directed primarily to the careful study and interpretation of the text of the Gospels.

Required of freshmen, first or second semester, two hours a week. two credits.

(b) Continuation of (a).

Elective, second semester, two hours a week two credits.

Students who are already fairly familiar with the gospels, or who for any reason prefer to do so, may, in lieu of the above, take Old Testament History. See course 9.

2. The Missionary Labors of the

Apostles.-

Professor Wallace These studies are based on the Acts of the Apostles and in part on the New Testament Epistles. The external and internal growth of the early church is carefully traced and the whole movement is viewed as a continuance of the work of Christ thru the agency of the Holy Spirit and of His inspired apostles. The authorship and credibility of the Acts, its teaching concerning Jesus, the Holy Spirit, and the organization of the early church receive special attention.

Required of sophomores, one year, one hour a week, two credits.

3. Prophets of Israel.-

Professor Wallace This course consists of a thoro study of the prophets, their place in the community, their functions and their messages. It is Dursued inductively from the Bible text with the object 
of acquainting the student as fully as possible with the foreshadowings of the Christ. All the Messianic passages are carefully analyzed with reference to their historical background and in the order of their development.

One year, two hours a week, four credits.

4. The Literary Study of the Bible.- Professor Wallace (a) This course includes a careful study of the Bible, viewed as literature. The rhetorical characteristics of the Hebrew language and the various literary forms of the Bible are closely examined. This done, various parts of the Bible best illustrating these forms and characteristics are critically studied and drawn out in their proper literary form. As sound literary criticism is based on a thoro study of the thought and thought-connections, the literary study of the Bible proves in practice a very valuable aid to interpretation. It is for this reason, especially, that it is included in the course. Much use is made of the text-books of Moulton and Genung.

Prerequisite, courses 1 and 2 . First semester, two hours a week, two credits.

(b) A continuation or repetition of (a) with literary study of various passages of Scripture and the application of the principles of literary criticism to their interpretation. credits.

Prerequisite, courses 1 and 2 . Second semester, two hours a week, two

6. Inter-Testament History.-

PROFESSOR Wallace This course is intended (1) to trace the history of the Jews from Malachi to John the Baptist under the Persians, Greeks, Maccabees and Romans; (2) to trace the rise of the various Jewish sects. A knowledge of the outward political fortunes of the Jews, as well as the movement of Jewish thought in this period is of great importance for an intelligent understanding of the ministry of Christ and His Apostles.

Prerequisite, courses 1 and 2. Second semester, two hours a week, two credits.

7. Oriental History Contemporary with

the Old Testament.-

Professor Wallace

This course includes (1) a study of the history and religion of Babylonia, Assyria and Egypt; (2) the relation of this material to the explication of Old Testament history. The course is based on the histories of Winckler, Rogers, McCurdy and others.

Prerequisite, courses 1 and 2. Second semester, two hours a week, two credits. 


\section{Biblical Pedagogy and}

Sunday School Work.-

Professor Wallace

This course includes: (1) a study of Jesus as a teacher-a careful consideration of the question, What made Him the Master Teacher of all time?-His mastery of the technique of educational methods as illustrated in the four Gospels; (2) methods of Bible study, teaching and of Sunday school work; (3) the influence of Christianity on the world's education. It is based mainly on the Master and His method (Griffith-Jones), Jesus as a Teacher (Hinsdale), The Making of the Teacher (Brumbaugh), Teacher Training with the Master Teacher (Beardslie), supplemented by lectures.

Second semester, two hours a week, two credits.

9. Review of Old Testament History.- PROFEssor Wallace This is offered in lieu of course 1 to college students who have had little or no opportunity of pursuing a consecutive study of Old Testament history before entering college. The history of Israel is pursued from the founding of the kingdom under Samuel till the fall of Jerusalem, by close consecutive study of Samuel I and II, Kings I and II, Ezra and Nehemiah.

One year, two hours a week, four credits. Elective either semester.

10a. Apologetics.-

Professor Wallace

A brief exposition of Christian theism. History of the presentation and defense of Christianity with special emphasis on the important episodes from the time of the early contact with Greek philosophy down to the modern adjustments with natural sciences, philosophy, sociology, and comparative religion. An analysis of the changing elements and the permanent elements in the various methods of commending the Christian religion.

First semester, two hours a week, two credits.

10b. Comparative Religion.-

Professor McRae A study of the great religious systems of the world including Hinduism, Buddhism, Zoroastrianism, Confucianism, Taoism, Shintoism and Islam, with readings from the sources. An analysis of the elements common to these systems and Christianity, and of the elements that are peculiar to Christianity. An examination of certain modern cults that have borrowed extensively from one or more of the above systems.

Second semester, three hours a week three credits. 
11. Christianity and the State- - Professor Wallace The object of this course is to train the student in Christian statesmanship, to ascertain and classify the biblical principles that have to do with the functions and problems of the state, including the state's international relations, to trace the influence of these principles in the development of free institutions, to make clear the moral basis of democracy, to show that the highest statesmanship must be Christian and that this statesmanship is imperatively demanded by present world conditions and that by these alone can party platforms and public policies be soundly tested.

For practice in this kind of thinking a thoro study of the League of Nations is made in the light of history, of conditions in Europe before and after the war and of Christian principles. This part of the subject is pursued with the aid of "The League of Nations," published by the Atlantic Monthly Press, and much collateral reading.

First semester, two hours a week, two credits.

12. International Lessons.-

Professor Wallace A course in the International Sunday School lessons. The aim of this course is to study the setting of the lesson, make careful analysis of the materials and discuss the pedagogical teaching of the lesson.

One year, one hour a week, two credits.

Other courses for which credit is given in the Bible Training Department are:-

Greek 9, Greek Testament.

I. Mental Science and Philosophy 2 and 11.

History 3 , The Reformation Period.

Social Service 1.

Vocation 1.

Equipment.-This department is equipped with

1. The Kent and Madsen wall maps.

2. The large relief map of Palestine, $8 \times 5$ feet, published by the Palestine Exploration Society of London.

3. The relief map of Jerusalem and its environs, $41 / 2 \times 4$ feet.

4. A missionary map of the world, $5 \times 9$ feet.

5. A chart, $22 \times 3$ feet, of ancient synchronological history.

6. Religious literature embracing over one thousand volumes.

7. The Thompson Reflectoscope and Stereopticon. 


\section{Social and Political Science}

\section{Professors Davis and WILSON}

The aim of this department is to acquaint the student as far as possible with the whole field of social life and activity.

All the courses may be counted toward a major or minor except 1 and 11 , which can only be counted toward a minor.

\section{A. Sociology}

\section{General Principles.- \\ PROFESSOR WILSON}

Under this head are included the history, various theories and principles of the science. Important aims are to show the extent of the field, to arouse an interest in the study, and to correct methods of sociological investigation.

Either semester, three hours a week, three credits.

3. History of Social Ideas.-

This course will include (1) the social views of the ancient nations; (2) the ideal republics from Plato down to the present;

(3) modern socialistic schemes. credits.

Prerequisite, course 1. Second semester, three hours a week, three

4. Social Psychology.-

A study of suggestibility, instinct, feeling, sympathy, imitation, conventionality, the crowd, public opinion, etc.

Prerequisite, course 1. First semester, three hours a week, three credits.

\section{B. Economics}

11. General Principles.-

A general survey is taken of the history, theories and generally accepted principles of the science. The latest edition of "Outlines of Economics," by Ely, will be used, supplemented by collateral studies in Adam Smith, Mill, Ricardo, Taussig, etc.

Either semester, three hours a week, three credits.

\section{History of Economic Theory.-}

This course will trace the development of economic thought in the principal nations of Europe and America, especially in relation to philosophy and conditions of environment. The histories of Haney, Ingram and Gide will be used for reference.

Prerequisite, course 11 . One year, three hours a week, six credits. 


\section{The Industrial History of England.-}

The intention of this course is to make the student acquainted with the salient features of England's industrial and commercial progress and thus prepare him for a study of the economic history of the United States. The works of Cheney, Ogg, Innes, Usher and others will be used for reference.

Prerequisite, course 11, second semester of alternate years, three hours a week, three credits.

17. Economic History of the United States.-

An historical study of American agriculture, commerce, transportation, industry and finance.

First semester, two hours a week, two credits.

\section{Political Science}

\section{Elements of Political Science.-}

The aim is to trace clearly the great and distinctive features in the governments of Europe and of the United States. credits.

Prerequisite, course 1 . Second semester, three hours a week, three

\section{Legal Science}

41. Roman Private Law.-

The object is to acquaint the student with (1) the origin and development of Roman Law; (2) its relation to modern systems of State Law. credits.

Prerequisite, course 1. First semester, three hours a week, three

43. Elements of Jurisprudence.-

Holland's "Jurisprudence" is used. The general subjects considered are Laws and Rights, Private, Public and Adjective Law, the object being to acquaint the student with the principles of fundamental law in their historical development and their practical application to the several phases of social life. credits.

Prerequisite, course 41. Second semester, three hours a week, three

44. Method and Teaching of the Social Sciences.-

The object of this course is to train the student in the methods of scientific approach and of instruction in the classroom. Analysis and discussion of representative treatises. Practical exercises by students.

Prerequisite, courses 1 and 11 . Second semester, three hours a week, three credits. 


\section{E. Anthropology}

51. Primitive Philosophy and Social Life.-Professor Wilson Philosophy and social life of primitive man. Illustrated by studies of the Hidatsa Indians. Text-book and lectures. credits.

Prerequisite, course 1. First semester, three hours a week, three

52. Physical and Cultural Anthropology.-PROFESSOR WILSON Ancient races of Europe; Paleolithic and Neolithic times; primitive arts and cultures, European and American. credits.

Prerequisite, course 1. Second semester, three hours a week, three

\section{Social Service}

\section{PROFESSOR McRAE}

Students majoring in Social Service, while conforming to the requirements of Group II, must include the following courses:- Biology 1 and 3 or Chemistry 1 , History 5 and 6 , Mental Science 4 , and Social and Political Science 8.

\section{Social Survey.-}

Growth of the social conscience; the field of social service; taking the initiative as a social citizen; a study of pathological conditions and processes in modern society; methods of family case work. Text-book, lectures, readings, inspection trips, field work, and survey assignments-the United Charities of St. Paul cooperating.

One year, two hours a week class work and three hours a week or more field work, six or eight credits.

2. Settlements.-

History, philosophy, development and spiritual significance of the settlement; neighborhood settlement activities; volunteers and their relation to settlement service; the settlement and its relation to other community organizations; settlements as an Americanizing force. Lectures, readings, participation in settlement work, friendly visiting, survey assignmentsthe Minneapolis Federation of Settlements cooperating.

Second semester, two hours a week class work and three hours a week or more field work, three or four credits.

3. Child Welfare.-

The obligations of society to the child; history of child-saving movements in the United States; home life of the child, education, recreation, illegitimacy, the establishing of paternity, adoption; child labor, delinquency, mortality; courts, institutions, societies and other public agencies for the child-the Children's Bureau of the State Board of Control cooperating. credits.

First semester, five hours a week class and field work, three or four 


\section{Immigration -}

History of world migrations; a survey of immigration to the United States; its sources, causes and social and economic effects; control and distribution; contribution of the immigrant to our composite life.

Prerequisite, Social and Political Science 52. First semester, two hours a week, two credits.

\section{Americanization.-}

A study of race characteristics, relationships, adaptability, assimilability; the view-point of the alien, special lectures by race leaders; practical methods of interpreting American ideals and institutions to the immigrant; laboratory work among foreign peoples in the community.

Prerequisite, course 4 . Second semester, two hours a week, two or three credits.

\section{Spanish \\ Professor Chalfant}

\section{Elementary Spanish.-}

Grammar, composition, conversation, reading.

One year, four hours a weck, eight credits.

2. Intermediate Spanish.-

Composition and conversation, together with readings largely from Latin American literature, and reports from Spanish periodicals.

One year, three hours a week, six credits.

\section{The Modern Spanish Novel.-}

Reproductions and reports.

One year, three hours a week, six credits.

4. Introduction to the Study of the Modern Spanish Drama.-

The authors to be especially studied-Galdos, the Quinteros, Benavente.

One year, three hours a week, six credits. Not offered 1923-1924.

\section{Advanced Composition.--}

This course consists of letter-writing, free reproductions and original compositions. As a part of the work there will be given a complete review of Spanish Grammar. credits.

Prerequisite, courses 1 and 2. First semester, two hours a week, two 


\section{Teachers' Course.-}

In this course the modern methods of teaching Spanish are discussed. Text-books and other supplementary books and material useful in the teaching of Spanish are recommended and examined. A review of Spanish grammar and a study of phonetics are carried on thruout the course. Observation of high school, college and university classes in Spanish, with reports on such observation is required.

Prerequisite, two years of Spanish. Second semester, three hours a week, three credits.

\section{Vocation}

The aim of this department is to acquaint students with the elemental laws and data of vocation, modern efficiency and personal, vocational and psychological development, and to teach them how to find themselves.

1. Vocational Fundamentals.-The following divisions of the subject will be included in this course: (a) a survey of the general field of vocational and life development; (b) lectures and experiments in methods of study to establish the habits of work for vocation and life; (c) lectures and surveys about college life as applied to the laws of occupation and career; (d) study of vocational and life charts; (e) expository themes to study and record student traits.

First semester. Required of freshmen, two hours a week, two credits. Not offered 1923-1924.

2. Vocational Development.-The following divisions of the subject will be included in this course: (a) the history of vocational guidance; (b) requirements and characteristics of various vocations; (c) lectures on the knowledge of human nature, and practical experiments in management; (d) occupational research with experimental psychology applied to vocation and personal efficiency; (e) success principles, biography and literature, reference readings; (f) modern, personal, professional, industrial, business and institutional efficiency; $(\mathrm{g})$ psychological tests conducted in the department of psychology, the data to be used with students in this course; (h) estimate and gradings of general traits of students in this course by professors in all departments of the college used as partial data for guidance; (i) personal conferences for the study of each student, and experiments to develop traits for vocational and personal fitness.

Perequisite, twenty-four credits. First semester, three hours a week, three credits. Not offered 1923-1924. 


\section{Physical Education \\ (Women) \\ MISS CROCKER}

\section{Personal Hygiene.-}

Short talks on the functions of the skin, the physiologic effects of water, hot and cold; bathing; care of the face; care of the hair, the hands, the feet; care of the mouth and teeth and their relation to good digestion; overeating and intestinal indigestion; fresh air; ventilation of bedrooms; care of the ears, throat and nose; deep breathing; the foot and the shoe; dress.

\section{Physical Training.-}

1. Corrective exercises: walking, standing and sitting. Elementary work in stall bars, parallel bars, ladder and horse.

2. Folk Dancing.

Required of freshmen, one year, two hours a week.

\section{Library Work}

The Saint Paul Public Library offers a course in the elements of library work, including the care and use of books. Students of Macalester College may take this course for college credit.

First semester, one credit. 


\title{
Macalester College Conservatory of Music
}

\author{
Telephone, Midway 2656 \\ Wallace Hall, Summit and Macalester Avenues \\ HARRY PHILLIPS \\ Director \\ JESSIE M. YOUNG \\ Secretary
}




\section{Faculty}

HARRY PHILLIPS, Mus. M., Director, ${ }^{*}$

Voice Culture.

GEORGE HERBERT FAIRCLOUGH, * Mus. M., Piano, Organ, Theory.

GEORGE KLASS, *

Violin.

HELEN E. BRIGGS,"

Piano, Normal, History of Fine Arts,

Senior Progressive Theory.

MARTHA ROGERS,*

Voice.

EMILY GRACE KAY,"

Piano, Public School, Harmony, History, Appreciation.

JESSIE MAY YOUNG, $\dagger$

Piano.

Junior Progressive Theory:

ROY FRANKSON, $\dagger$

Violin.

MYRTLE WEED, $\dagger$

Piano.

MARGARET MOUNT, $\dagger$

Piano.

CLAIRE THORALDSON, $\dot{\dagger}$ Assistant in Piano.

HELEN HARRIS, $\dagger$

Assistant in Violin.

MRS. MAXMILLIAN DICK, $\dagger$

Violin and Cello.

*American and European Education.

$\dagger$ American Education. 


\section{Course of Study}

The Conservatory of Music offers a thoro course of instruction in voice, piano, organ, violin and other stringed instruments; also a theoretical course including harmony, counterpoint, composition, musical history, appreciation of music and public school music. In each branch of musical study a systematic course, leading to graduation, will be pursued. Time required for completion varies-the length of course depending on the pupil's ability and intelligent devotion to work.

Entrance.-Pupils who expect to graduate must enter at the beginning of the school year. Those not wishing to graduate may enter at any time in the year.

Upon entrance pupils are examined, classified and placed in their fitting grade, by the director.

Teacher's Certificate.-Teachers' certificates will be given to all pupils who have taken the Normal course and completed the junior year in full to the satisfaction of their individual teachers.

Diploma from the Conservatory of Music.-A student, to receive a diploma, must have completed the work of the senior year in full, written a graduating thesis, given a whole or such part of a program as the director may decide upon, and taken part in the graduating program of the Conservatory of Music.

Diploma with the Degree of Bachelor of Music.-Candidates for the degree of Bachelor of Music are required to take at least fifty semester hours of strictly college work (including history of art and physical training) and at least seventy hours of music. All college entrance requirements must be met and the credits for them presented to the Registrar of the College. Exceptions to the general graduation requirements, in the case of candidates for this degree, are a requirement of eight credits in religious education and of at least two years of a modern language in college. Such as have no modern foreign language upon entering must take three years of such language in college. Students electing Voice are strongly urged to take two years each of French and German.

The following college subjects are required for this degree: English, six credits; Religious Education, eight credits; Modern Foreign Language, fourteen credits (if deficient at entrance, three years); History of Art, four credits; Physics 6, two credits. In addition to the above required credits, electives sufficient to make a total of fifty credits. 
Music subjects are required as follows: Harmony, Counterpoint, Composition and Orchestration, sixteen credits; History of Music, eight credits; Appreciation, four credits. In addition to the above there are required a major of twenty credits, and a minor of twelve credits. Electives may be chosen from Voice, Organ, Piano, Violin, Public School Music, to complete the requisite number of credits.

In order to make such a course profitable it is naturally required that the student give evidence at entrance of a sufficient preparation in some branch of music.

Special courses are offered those living in the city who do not wish to take the regular course.

Standardization of Music Teaching.-Macalester Conservatory, after thoro investigation, has adopted the Godowsky Progressive Series of Music Lessons, now being used by over 10,000 educational institutions, conservatories and music teachers of America, as the standard for music credits. A number of states have placed music study, when carried on systematically, on an equal basis with the study of all other branches of learning and allow it full credit.

In 1916, the Cornell University Official Announcement stated: "Standardization of music teaching and of credits for the study of music are subjects receiving attention by the educational authorities thruout the country. It will soon be the rule, rather than the exception, to give credits toward graduation for the study of music. The Progressive Series of Piano Lessons makes possible the standardization of music teaching and solves most of the difficulties which have hitherto prevented the adoption of a system of credits for study of music."

In its editorial staff and list of contributors are assembled twenty eminent musicians and educational authorities, the greatest aggregate of musical and pedagogical intellect and talent ever gathered in a combined effort to further the cause of musical education.

The editor-in-chief is Leopold Godowsky, the renowned artist and composer, now at the very height of his powers. His improved methods of study are fully set forth in the Progressive Series. The principles of the other world "methods" are also shown. The asscciate editors are Edgar Stillman Kelley, one of America's foremost composers, Josef Hofmann and Emil Sauer, the famous pianists. 
Godowsky himself says, "We have striven to make it an educational work in the form of a progressive and complete series, that, from both an artistic and pedagogical standpoint, would be superior to anything ever offered to the public."

Graduates will receive not only the diploma of the Conservatory, but also the certificate of the course. We wish to impress upon the parents and pupils that the use of this series will in no way interfere with either the individuality of the pupil or the particular views of any individual teacher.

Mr. Fairclough, Miss Briggs, Miss Weed, Miss Young and Miss Mount will instruct in the Progressive Series, a valuable addition to our regular work, which has been so generously approved by the music-loving public of the Twin Cities.

\section{Voice}

In the department of vocal music those methods which experience justifies as being at once effective and artistic in their results have been adopted. It is the policy to secure a systematic and thoro culture on the basis of the best methods.

Intermediate Year.-Vocalises by Sieber, Concone, and the study of songs, ballads by Larsen, Grieg, Buck, Gounod and others, make the first year's work complete.

Junior Year.-Studies in phrasing and rapid execution, German songs by Mozart, Schubert, Schumann, Liszt, Franz, Beethoven, etc., also some of the lighter selections from the operas.

Senior Year.-Oratorio in all forms, Bach, Haydn, Handel, Mendelssohn, Gounod, Verdi. Selections from the heavier operas and songs of the modern school. Frank, Wolf, Homer, Tours, Massenet, Dvorak, Ronald, Nevin, Ganz.

Every student graduating in vocal music must have at least one year of French.

Graduate Course.-Aims to develop the artistic sense to a still greater degree, according to art traditions. 


\section{Pianoforte}

Individual instruction is given and the regular course calls for one hour's instruction a week, divided into two lessons of thirty minutes each. Where but one lesson a week is taken the lesson will be forty-five minutes in length.

Preparatory.-Thoro grounding in hand; finger and arm training. Rudiments of music. Easier studies to suit capabilities of each pupil. Pupils are thoroly prepared for the entrance into the three years' course.

Intermediate.-Czerny, Velocity Studies; Bertini, Loeschorn, Heller, etc.; Bach-Little Preludes and Fugues; Sonatinas and Easy Sonatas.

Junior Year.-Czerny, Op. 740; Cramer-Bulow, Fifty Selected Studies; Heller, MacDowell, etc.; Bach, Two- or Three-Part Inventions, French Suites; Sonatas of Mozart, Haydn and Beethoven.

Senior Year.-Clementi, Tausig, Gradus ad Parnassum, Czerny, Op. 740, Chopin Etudes, Kullak Octave School, Bach's Fortyeight Preludes and Fugues; Sonatas and Concertos of Beethoven and other masters. Repertoire from classical and modern composers.

In each grade suitable pieces will be given as the pupil is ready for them.

Postgraduate.-Advanced work. Continuation of previous year. Concertos (with second piano or orchestra accompaniments).

\section{Violin}

The violin department has become a leading feature in the musical life of all conservatories. Year by year the number of violin students is increasing. To keep pace with the demands of the time this department of our school has been developed until today it presents exceptional advantages for the study of what is called "the most perfect musical instrument known."

The violin course is not expected to be followed strictly, nor does it claim to be complete. In the private lessons each pupil can be favored with studies which suit his or her special requirements. With the technical course a selection of compositions from the whole range of violin literature up to the present time will be used. These will be chosen from the representative composers of the different periods and schools, with the intention of giving the pupils a knowledge of the individual interpretation of each kind.

Scales, bow and finger exercises will be used as needed to meet the requirements of the various pupils. 


\section{Pipe Organ}

Before beginning the study of the pipe organ the student should have had at least one year's instruction on the piano and should have a thoro knowledge of the rudiments of music.

\section{Public School Music}

This is a two-year course. Entrance to the course requires that the student have a diploma from an accredited high school. Upon satisfactory completion of this course a State certificate will be issued in addition to the Conservatory certificate. Under certain conditions this course may form a portion of the work for the regular diploma of the Conservatory of Music.

First Year.-The following subjects are required: Sight-singing, Ear Training, Voice Culture, History of Education, Psychology, Harmony 1, a modern language or its equivalent, Piano, unless able to play third grade music, in which case candidate may be excused from further study of that instrument. It is very desirable that a student be able to teach some high school subject or drawing in connection with Public School Music.

Second Year.-The following subjects are required:

Sight-singing, Ear Training, Harmony 2, History of Music, Appreciation of Music, Piano, unless able to play third grade music, a modern language or its equivalent.

Practice teaching is required.

The study of voice will be required of pupils in public school music to meet this demand.

\section{Normal Training}

The demand of the times is for musicians equipped not only technically, but also in the art of imparting instruction. Most students, in starting to teach, possess but the points given them by their instructors, in regard to their individual work. As these may not apply to the general needs of their pupils a course in the art of teaching is almost indispensable.

Normal Piano Training Course for Prospective Teachers.One year course with Certificate for advanced and senior students of piano.

Post-graduate Certificate Course for young teachers.

(For College Credits see College Catalog.)

Text-book work, practice teaching. 
Lectures.-Technical Theories, Various Types of Pupils, Elementary Foundation Work, Development of Original Musical Ideas, Tonality, Methods, Material for Teaching, Interpretation, Memorizing, Educative Principles, etc., etc.

Ear training, analyzing and psychology are a part of this course. (College students will take the regular college course in psychology; music students, a special course at the conservatory.)

Normal Courses in Voice and Violin may also be taken.

\section{Ensemble}

The study of chamber music is a very important one to the advanced student of any instrument. The impetus to more thoro practice, mental activity, development of rhythm and color, and an insight into this particularly rich field of musical text, is of untold value. Both classic and modern music is studied. Students who come mainly for the study of piano, violin or any other instrument should, if possible, arrange for some work in this line.

\section{Harmony}

The "Upton" system of key-board harmony will be used. Harmony study is too apt to be purely theoretical and therefore of comparatively slight value to the average student. Believing that a course has been found that will be first, last and always of practical value to the performer, since all the work is done at the instrument, we are offering this advantage to our students. Results obtained in other institutions substantiate all the claims made for the system. The student uses with fluency all the triads and seventh chords, modulates to all keys with ease, is familiar with altered chords, and suspensions, in short with all the subjects covered in any harmony course. He is enabled to transpose music as easily as he plays it in the original key. As memorizing is a great feature of the course it becomes an easy and natural process. Very young children are enabled by this course to produce compositions of real merit.

\section{Theory}

The importance of exhaustive and thoro work in the various theoretical studies cannot be too strongly emphasized. A rudimentary or fundamental course should precede ear training, sight singing, harmony, analysis, counterpoint (simple and double), canon and fugue (the supreme contrapuntal forms), orchestration and composition.

Progressive Series Theory, of junior and senior grades, is required for graduation from the conservatory. 


\section{Appreciation of Music}

First Year.-This is a study of the form and meaning of music and follows closely the text used, "Appreciation of Music" and Supplement, by Surette and Mason. A preliminary study of the instruments of the orchestra is given, preparatory to the concerts of the Minneapolis Symphony Orchestra, which our students are encouraged to attend. Required for graduation from Conservatory of Music.

Second Year.-This is a continuation of Appreciation of Music 1 , and is a thoro study of Romantic and Modern forms since the time of Beethoven. The study is based on "Appreciation of Music," volume 2, by Surette and Mason, and "What We Hear in Music" by Faulkner. Talking machine records are freely used. Required for graduation from the Conservatory of Music.

\section{History of Music}

First Year.-Study of beginnings of music thru the Classical Period, including the history and development of instruments. The text-book used is "Essentials in Music History," Tapper and Goetschius. The college library has a good collection of reference works on music and our students have access to the fine collections in the public libraries of St. Paul and Minneapolis. A trip is made annually to the Raudenbush piano factory in St. Paul to see the process of making a piano. Required for graduation from Conservatory of Music.

Second Year.-This is a continuation of History 1, studying the development of music from the Romantic Period to our own day. By means of the talking machine records many operas, oratorios, symphonies, songs and piano compositions are studied. Required for graduation from Conservatory of Music.

\section{History of Fine Arts}

Thr study of the allied arts is of great cultural advantage to the musician in the development of artistic tastes. Instruction in the way of illustrated lectures is given by Miss Briggs. See History 12. 


\section{Student Recitals}

These opportunities for public performance are helpful in overcoming natural diffidence and nervousness, and in giving that confidence and poise so necessary to the successful player and singer.

Pupils also gain an ever-increasing knowledge of musical text, aside from that with which they come in contact in their own study. The instructors allow only such students as have reached a certain degree of proficiency to appear in recital.

\section{Terms for Instruction}

\section{Per Semester}

Tuition prices vary with the grade and the teacher.

Voice.............................. $\$ 144.00$ to $\$ 31.50$

Piano................................. 18.00 to

Pipe Organ............................ 72.00 to 45.00

Violin............................. 72.00 to 18.00

Ensemble............................... 25.00

Harmony.............................. 20.00

History of Music......................... 6.00

Appreciation of Music........................ 5.00

Public School Music............................ 40.00

Normal Piano Training. ......................... 40.00

Progressive Series.......................... 10.00

Piano Practice, per hour . \$6.00 Organ Practice, per hour 12.00

Incidental Fee........ $1.00 \quad$ Cost of Graduation .... 10.00

College fees for conservatory students taking college work are paid at the beginning of each semester before completion of registration and strictly in advance, as follows:-

Tuition (five to eight hours per week) $\ldots \ldots \ldots \ldots \ldots \ldots \$ 45.00$

There is no fee for harmony, history or appreciation to students taking college subjects.

Discount will be allowed on tuition bills for two or more studies paid a year in advance. 


\section{Honorary Degrees}

Conferred by Macalester College

1901: D. D. to Rev. Charles Thayer, Ph. D........ Deceased

D. D. to Rev. George W. Davis, Ph. D...St. Paul, Minn.

1902: D. D. to Rev. H. F. Stilwell.............. Paul, Minn.

D. D. to Rev. J. Le Moyne Danner...... Indianapolis, Ind.

LL. D. to Hon. Thomas Wilson............. Deceased

1903: D. D. to Rev. Joseph Cochran, Macalester, ' 89.

............................. Detroit, Mich.

1904: D. D. to Rev. Stanley B. Roberts......Minneapolis, Minn.

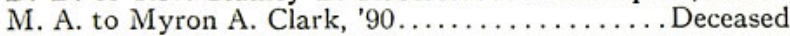

1905: D. D. to Rev. Charles F. Hubbard.......... Auburn, N. Y.

1906: D. D. to Rev. Donald D. McKay........ Tacoma, Wash.

1907: D. D. to Rev. Archibald Cardle, Macalester, ' $94 \ldots . . . .$.

. Burlington, Iowa

1910: D. D. to Rev. Charles T. Burnley............ Deceased

D. D. to Rev. Alfred E. Driscoll.......... Detroit, Mich.

D. D. to Rev. William Porter Lee, Macalester, ' $89 . . . . .$. . Germantown, $\mathrm{Pa}$.

D. D. to Rev. Harry Clinton Schuler, Macalester, ' $95 . .$. ..Teheran, Persia

D. D. to Rev. John Hansen Sellie, Macalester, '95.

Le Sueur, Minn.

1911: D. D. to Rev. Charles Allen Clark, Macalester, '99...... . Pyeng Yang, Korea LL. D. to Rev. Albert Brainerd Marshall, D. D., Clarinda, Ia. LL. D. to Rev. George Livingstone Robinson, Ph. D., D. D.

Chicago, Ill.

1914: D. D. to Rev. George Ewing Davies..Salt Lake City, Utah

D. D. to Rev. Joseph Carle Robinson..... . Philadelphia, Pa. LL. D. to Hon. James Jerome Hill........... Deceased

1915: Litt. D. to Rev. John Wright ........... Deceased D. D. to Rev. William C. Laube '01 ..... Dubuque, Ia. 1916: Mus. M. to Harry Phillips.............Minneapolis, Minn. Mus. M. to George H. Fairclough ......... St. Paul, Minn.

1918: D. D. to Rev. Asa John Ferry .............. Chicago, Ill.

D. D. to Rev. James B. Lyle............. Albert Lea, Minn.

D. D. to Rev. T. Ross Paden .............Mankato, Minn.

D. D. to Rev. Benjamin Bunn Royer .........Franklin, Pa.

1919: LL. D. to Rev. Dwight Witherspoon Wylie, Philadelphia, Pa.

1920: D. D. to Rev. Paul Doeltz................... Philippines

D. D. to Rev. Thomas W. Graham .......... Oberlin. Ohio

1921: D. D. to Rev. Peter Erickson ............... Minot, N. D.

D. D. to Rev. Thomas M. Findley.......... Spicer, Minn. 


\section{Alumni}

\section{Alumni Association}

It will be esteemed a favor if each alumnus who changes his residence will notify the President of his new address. Information from any source that will assist in keeping this roll complete will be appreciated.

The Alumni Association of Macalester College has two purposes in view: to bind into a unit the graduate body and help to preserve and increase the value of the friendships formed in college, and to further the interests of the Alma Mater and make her more widely known. Communications to the Alumni Association should be sent to the college.

\section{Officers}

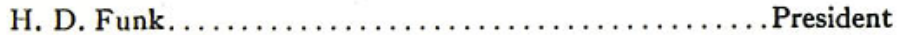

Gertrude Smith . . . . . . . . . . . . . . . . . . Vice-President

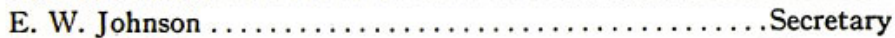

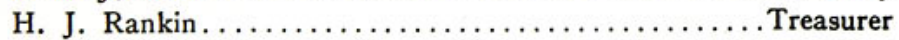

\section{Roll of Alumni}

\section{Class of 1889}

George Washington Achard .............. Business, Minneapolis, Minn. Joseph Wilson Cochran.......................... Minister, Detroit, Mich. Ulysses Grant Evans. .............................. Minister, Atalissa, Iowa James Chase Hambleton................... Teacher, Columbus, Ohio

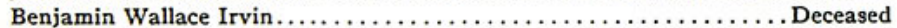
Samuel M. Kirkwood......................... Surgeon, Absarokee, Mont. William Porter Lee..................... Minister, Germantown, Pa. Paul Erskine McCurdy............................. Puiness, Philadelphia, Pa. Louis Ferdinand Slagle $\ldots \ldots \ldots \ldots \ldots \ldots \ldots \ldots \ldots \ldots \ldots \ldots$ Deceased

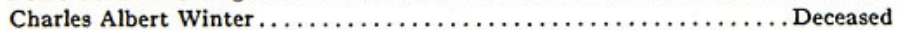

Class of 1890

Myron A. Clark . . . . . . . . . . . . . . . . . . . . . . . . . . Thaddeus T. Cresswell . . . . . . . . . . . . . .

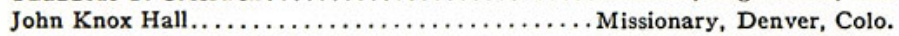
William Henry Humphrey . . . . . . . . . . . . . . . . . . . . Deceased William Paul Kirkwood ............... Professor, U. of M., St. Paul, Minn. Amos Avery Randall . . . . . . . . . . . . . . . . . . . . . . . . . . . . . Deceased Judson L. Underwood. ............... Missionary, Cebu, Philippine Islands 


\section{Class of 1891}

Frank Brown $\ldots \ldots \ldots \ldots \ldots \ldots \ldots \ldots \ldots \ldots$ Principal, Chlcago, Ill.

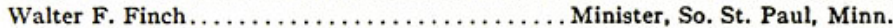

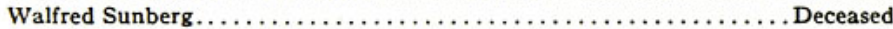
William B. Turner . . . . . . . . . . . . . . . . . . . Business, Thomas C. Williamson.................. Business, Winnebago, Minn.

\section{Class of 1893}

James Carlisle Simonton. . . . . . . . . . . Business, Minneapolis, Minn.

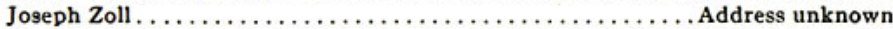

\section{Class of 1894}

Francis W. Beidler........................... Minister, Mosco, Colo.

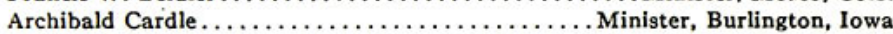

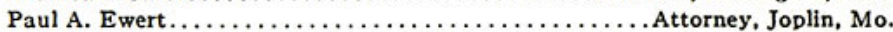
George E. Johnson. . . . . . . . . . . . . . . . . . . . Business, Boulder Creek, Cal. Samuel M. Marsh . . . . . . . . . . . . . . . . . Minister, Brown's Valley, Minn. William H. Sinclair ........................ Minister, Oxford, Iowa

\section{Class of 1895}

Frank E. Balcome . . . . . . . . . . . . . . . . . . Physician, St. Paul, Minn. John W. Christianson......................... Minister, Watertown, S. D. Thomas Fitz-Morris Clark . . . . . . . . . . . . . . . . . . Deceased Charles D. Darling. .......................... Minister, Cleveland, Ohio Edwin Howard Gordon.$\ldots \ldots \ldots \ldots \ldots \ldots \ldots \ldots \ldots \ldots \ldots \ldots$ Deceased Harry Clinton Schuler..................... Missionary, Teheran, Persia John Hansen Sellie..................... Minister, Le Sueur, Minn. Arthur Whitney Vance.$\ldots \ldots \ldots \ldots \ldots \ldots \ldots \ldots \ldots \ldots \ldots$ Deceased

\section{Class of 1896}

Alexander Edward Cance.......... Prof., Mass. Agr. College, Amherst, Mass. Moses M. Maxwell. . . . . . . . . . . . . . . . . . . . . . . . . Deceased

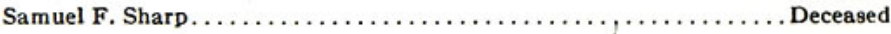

\section{Class of 1897}

Albert Ernest Evans..................... Minister, Yakima, Wash.

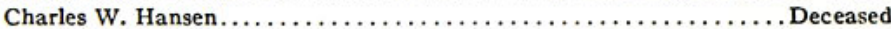

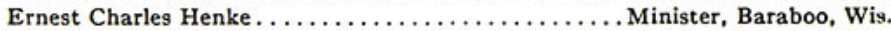

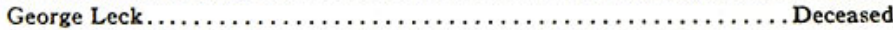
John McLearie...........Professor, State School of Mines, Rapid City, S. D. Winifred Moore-Mace...............................

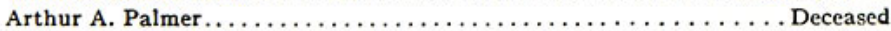
Charles Petran ......................... Missionary, Mexico City, Mexico

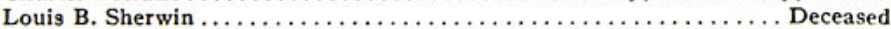
William K. Sherwin. .................... Minister Brown's Valley, Minn.

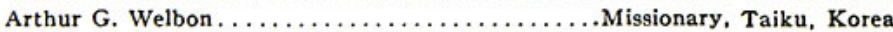

\section{Class of 1898}

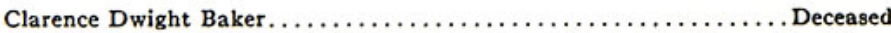

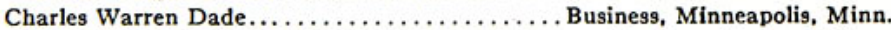
Anna Moore Dickson................... Teacher, St. Paul, Minn. 
Caspar Gregory Dickson........... Library of Congress, Washington, D. C. Nellie M. Flanders-Sherwin.................. Brown's Valley, Minn. John M. Guise . ..................... Princıpal, St. Paul, Minn.

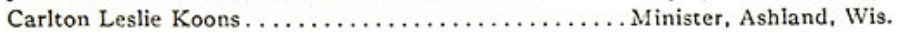

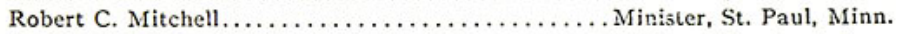
William James Mitchell. ..................... Minister, Hamburg, Iowa

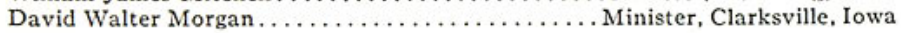

\section{Class of 1899}

Hugh S. Alexander........... Professor, Macalester College, St. Paul, Minn. Walter Baker Augur....................... Charles Allen Clark. . . . . . . . . . . . . . . Missionary, Pyeng Yang, Korea Ralph Elmo Clark................... Teacher, Moose Jaw, Sask., Can. Paul Doeltz....................... Missionary, Iloilo, Philippine Islands George C. Edson............................ . . . . . . Thomas George Jamieson. . . . . . . . . . . . . . . Business, Calgary, Almira F. Lewis . . . . . . . . . . . . . . . . . . . . . . . . . Denver, Colo.

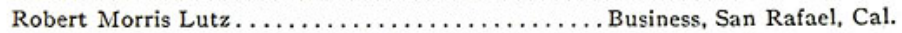

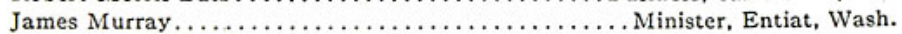
Samuel Merton Pinney.................. Superintendent, Mound, Minn. Jacob Elmer Smits. . . . . . . . . . . . . . . . . . . . . . Deceased George Stanley.......................... Minister, St. Paul, Minn. Murray Alberton Travis.................... M. C. A., Homer, La.

\section{Class of 1900}

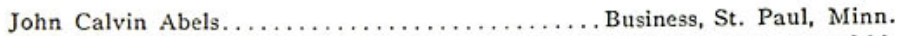

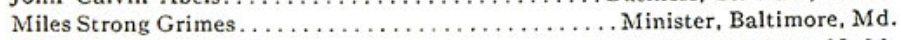
Ralph Emerson Herron..................... Business, Lordsburg. N. M. John Robert Landsborough. . . . . . . . . . . . . . . Minister, Anacortes, Wash. Ernest A. Oldenburg. . . . . . . . . . . . . . . . . Minister, Earl Park, Ind. Mathilde Pederson-Romunstaad . . . . . . . . . . . . . . . . . Deceased

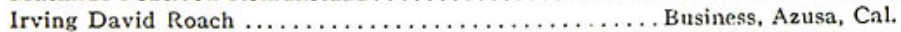

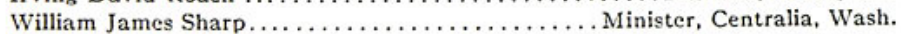
Roy Walker Smits. . . . . . . . . . . . . . . . . . . . . . . Deceased David A. Thompson......................... Oinister, Portland, Ore.

\section{Class of 1901}

William Beckering. . . . . . . . . . . . . . . . . . . . . . Deceased

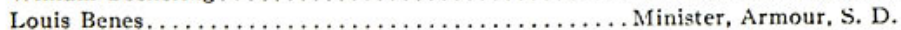
Henry Roy Bitzing. ........................... Uajor, S. A., Washington, D. C. Percy Porter Brush.................................. Tacoma, Wash. Charles Morrow Farney . . . . . . . . . . . . . . Business, St. Panl, Minn. Henry D. Funk. ............ Professor, Macalester College, St. Paul, Minn.

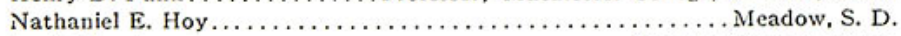
Lewis Hughes. ........................ Teacher, Ottawa, Munn. Richard U. Jones............. Professor, Macalester College, St. Paul, Minn.

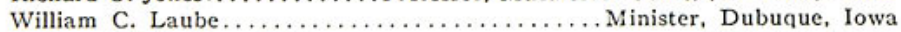
Millicent V. Mahlum-Kelts . . . . . . . . . . . . . . . . .

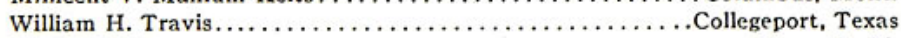

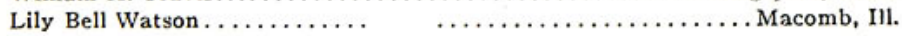




\section{Class of 1902}

Frederick Brown Deceased

Robert L. Davidson Teacher, Kent, Wash.

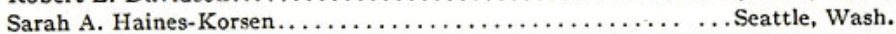
Grace Iddings-Fletcher . . . . . . . . . . . . Leonard L. Mann...............................

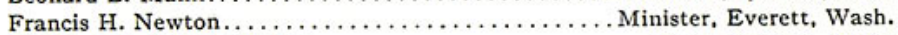
Winifred R. Pringle-Weber. . . . . . . . . . . . . . . Coeur daho Edgar E. Sharp ................................... Moorhead, Minn. Benjamin Bruce Wallace............ Tariff Commission, Washington, D. C. Helen Margaret Wallace-Davies................. Patoka. Ind,

\section{Class of 1903}

John Morton Davies Minister, Patoka, Ind.

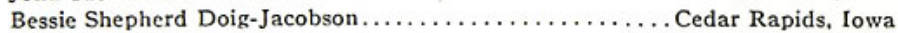
Julia Anita Elmer ...................... Teacher, St. Paul, Minn. Peter Erickson . ......................... Minister, Minot, N. D. Ebenezer Thomas Ferry .................... Minister, Worland, Wyo. Emma Inez Godward-Davies..................... Fairbury, Neb.

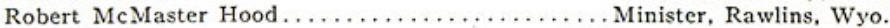
Peter Westin Jacobson.................... Minister, Cedar Rapids, Iowa Raymond Lewis Kilpatrick........... Engineer, Foremost, Alberta, Canada Donald Norman MacRae.................... Minister, Mitchell, Ont.

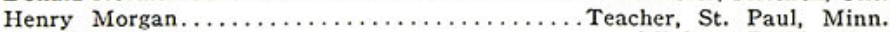
Joseph E. Rankin......................... Minister, Delhi, Minn. Mary J. Rankin.................... Missionary Teacher, Sneedville, Tenn. Max M. Wiles........................... Minister, Virginia, Ill.

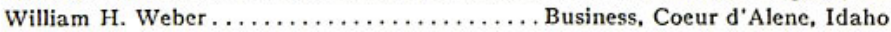

\section{Class of 1904}

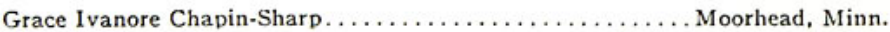

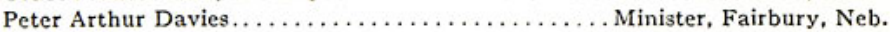
Thomas Hunter Dickson................... Physician, St. Paul, Minn. Margaret Evans-Detweiler.................... Tarrytown, N. Y. William Horatio Kendall. . . . . . . . . . . . . . Minister, St. Louis, Mo. Alfred Edward Koenig.................... Professor, Butte, Mont. William Oliver Rothney.............. Inspector of Schools, Quebec, Can.

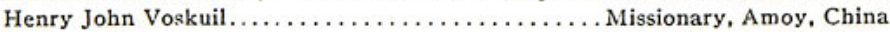
Tolbert Watson . . . . . . . . . . .

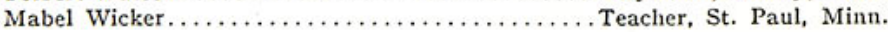

\section{Class of 1905}

John Thomas Anderson.................. Minister, Ishpeming, Mich.

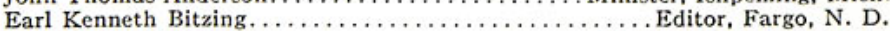

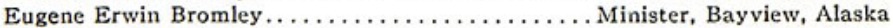

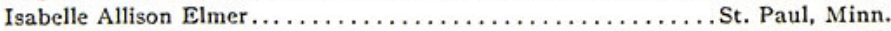
Asa John Ferry.............................. Thomas Edwin Flinn................ Physician, Redwood Falls, Minn.

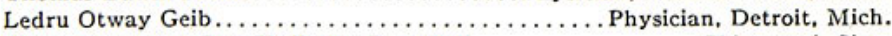
Mary Carnahan Guy-Shellman-Campbell............. Chiengmai, Siam Marie Grace Jamieson-Smith .................. . Lewisville, Ind. 
Daniel Griffin Le Fever .................... Business, Minneapolis, Minn.

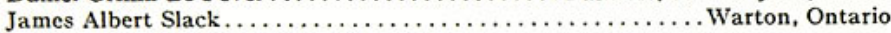

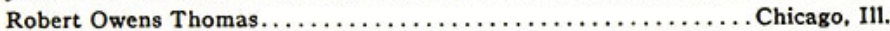
Jane Turnbull........................... Teacher, Eveleth, Minn.

\section{Class of 1906}

Levi H. Beeler................. President State Normal, Minot, N. D. James Ekin Detweiler..................... Missionary, Fukui, Japan James Hamilton ............................. Minister, Omaha, Neb. Roscoe Cliver Higbee..................... Principal, St. Paul, Minn. Alexander Hood.$\ldots \ldots \ldots \ldots \ldots \ldots \ldots \ldots \ldots$ Missionary, Wellpinit, Wash. Albert Kuhn $\ldots \ldots \ldots \ldots \ldots \ldots \ldots \ldots \ldots \ldots \ldots \ldots \ldots \ldots \ldots \ldots \ldots \ldots \ldots$ Minter, Omaha, Neb. Paul H. Th. Rusterholz ................... Teacher, St. Paul, Minn. Ruth Estelle Swasey-Rusterholz.................... Paul, Minn. Gordon Graham Thompson................. Physician, Seattle, Wash. Frank Harvey Throop..................... Missionary, Soo Chow, China Margaret Turnbull ..................... Teacher, St. Paul, Minn.

\section{Class of 1907}

William Harvey Amos....................... Minister, Parkdale, Ore. James Albert Caldwell . . . . . . . . . . . . . Principal, Tower City, N. D. Robert W. Davies....................... Business, Minneapolis, Minn.

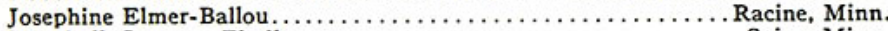

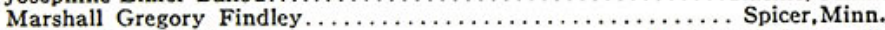
Richard David Hughes. ..................... Minister, Chicago, Ill. Martha Antoinette Jacobson-Maitrejean................ Paul, Minn. Henrietta Cecelia Lundstrom............... Teacher, Northfield, Minn.

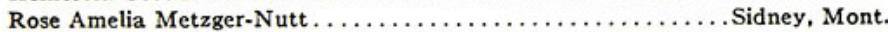

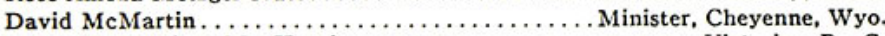
Rhoda Catherine MacKenzie.......................

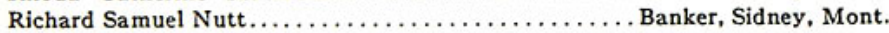
Ole Johnson Oie.............. President Theo. School, Christiania, Norway William Fred Pottsmith . . . . . . . . . . . . . .

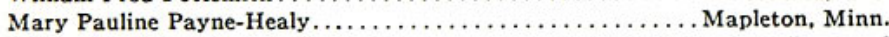

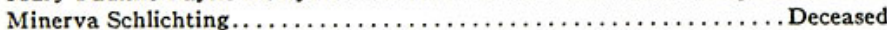
Ruth Adelia Sherrill...................... Teacher, Bothell, Wash. Mary Helen Smith-Jones........................ Paul, Minn. George Hill Smith .................... Business, Excelsior, Minn.

\section{Class of 1908}

George Kemp Aiken. . . . . . . . . . . . . . Hanna Sophia Berg. . . . . . . . . . . . . . . . Graduate Student, U. Ralph Brinks........................ Teacher, St. Paul, Minn. Richard Stanley Brown................. Minister, Sault Ste. Marie, Mich.

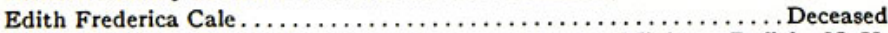
Clifford Clement Cornwell............................ Evan Milton Evans....................... Rosella Evans-Griffith . . . . . . . . . . . . . . . . . . . . .

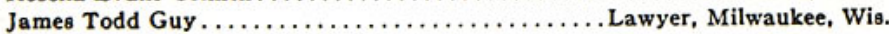


Mary Elizabeth Guy-Wallace..................... Me Mars, Iowa Walter Mell Hobart.................. Business, Minneapolis, Minn. Lucy Ma Belle Hyslop-Flinn................ Redwood Falls, Minn. Nina Foy Johnson-Wallace............................ Maul, Margaret Edith Lakey-McDonald ........................... Peter McEwen. ........................... Minister, Indianapolis, Ind.

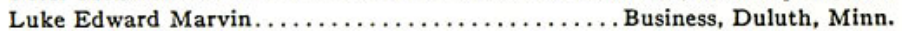

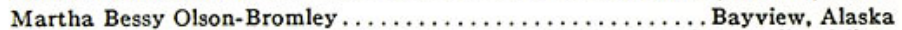

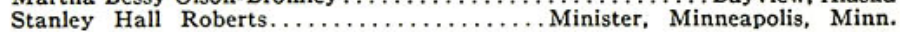

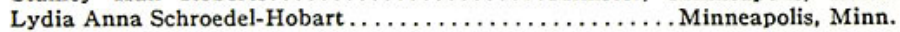
Clarence Mason Stearns................... Business, St. Paul, Minn. Robert Sinclair Wallace................... Business, St. Paul, Minn.

\section{Class of 1909}

Emma Bertelle Barker-Marvin....................... Duluth, Minn.

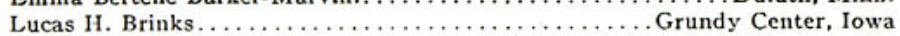

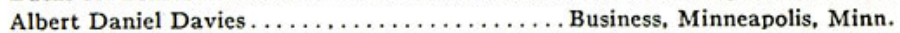
David Roy Jones. . . . . . . . . . . . . . . . . . . . . . . . . .

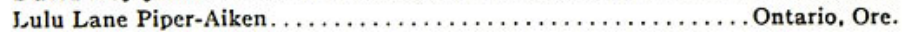

\section{Class of 1910}

George Samuel Barclay Acheson General Board of Education, New York City William Jefferson Bell................... Minister, Mountain Iron, Minn. Joseph Vaclav Beran...................... Business, Hibbing, Minn. Charles Taylor Burnley............................ Edward John Carson............................. Minister, Carbondale. III. John Andrew Evert. ........................ Physician St. Paul, Minn.

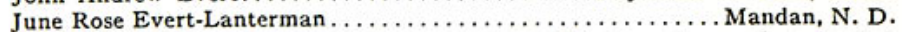
Albert Howard Gammons. . . . . . . . . . . . . Minister, Arroyo Grande, Cal. Jesse Willis Hamblin ....................... Minister, Canon City, Col. Stanley Hurlbut Hodgman . . . . . . . . . . . . . Business, Elk River, Idaho William Andrew Horne......................... Minister, Cornell, Wis. Helen Mary Hunt-Bell. .........................

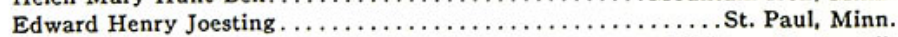
John Archibald McEwen ...................... Minister, Homer, Ill.

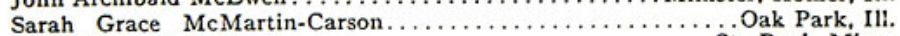
Pearl Alma Nash-Evert.......................... Paul, Minn. Mildred Gretchen Phillips-Kindy..................... Paul, Minn. Minnie Mae Pierson-Evans. . . . . . . . . . . . . . . . . . Middle River, Minn. Mary Elsie Raymond-Muhr . . . . . . . . . . . . . . . . . . . . .

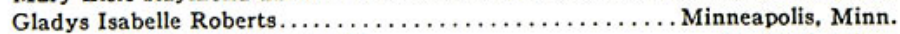
Jeannette Paulina Sawyer-Guild . . . . . . . . . . . . . . . . St. Paul, Frederick Samuel Shimian. . . . . . . . . . . . . . . . . . . . . Elmer Stuart Smith................................... Centralia, Wash. Elizabeth Libby Staples-Brown. . . . . . . . . . . . . . . . . . . .

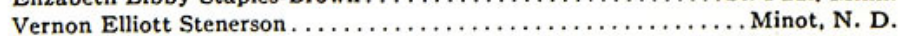

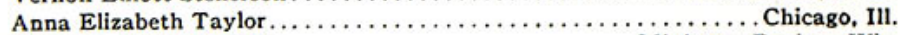
Norman Kendall Tully................................ Ruth Minerva von Dorn-Gammons. . . . . . . . . . . . . Arroyo Grande, Cal.

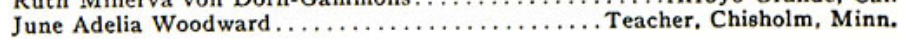




\section{Class of 1911}

William Ernest Baskerville................... Minister, Langlois, Ore. Charles Bremicker.......................... Minister, Hastings, Nebr. Allan Hill Brown . . . . . . . . . . . . . . . . . Minister, Lawrenceburg, Ind.

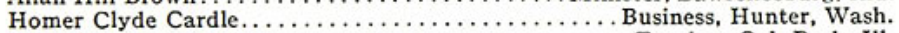
Fred F. Carson........................... Teacher, Oak Park, Ill. Janet Isabella Dodds.................... Principal, Cristobal, Canal Zone

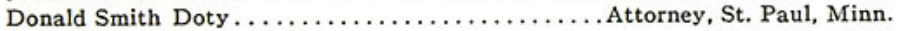
Effie Miranda Ellison-Miner..................... Coleraine, Minn.

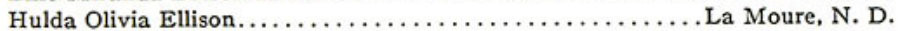
Oscar Melvin Ellison................................ Dusiness, La Moure, N. D.

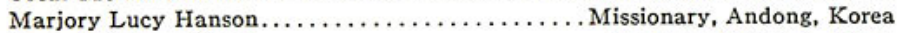

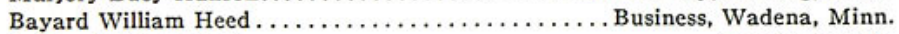

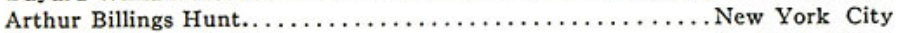

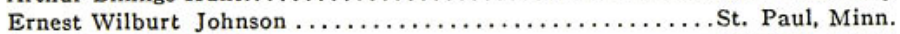

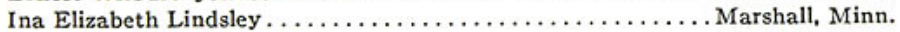
Anna Mae Little-Johnson........................ Paul, Minn.

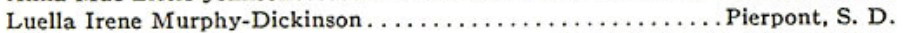
William Earls Noyes.................. Superintendent, Tower, Minn. Adelaide Wadsworth Payne-Keller........................... Minn. Russell Stephen Peterson............... Superintendent, Henderson, Minn. Leland William Porter............................

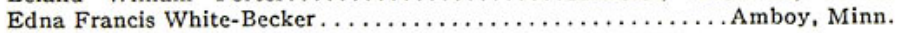

\section{Class of 1912}

Anna Elizabeth Anderson-Carson ..................... Carbondale, III. Dorothy Elizabeth Baumgart................ Teacher, St. Paul, Minn. Clara Berdan......................... Teacher, Albert Lea, Minn. James Brinks........................ Business, Independence, Kans.

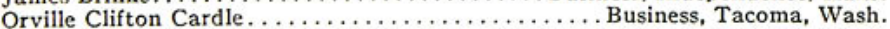
Bessie Florence Clark-Cardle...................... Tacoma, Wash. Mabel Emma Cosgrove..................... Principal, Le Sueur, Minn.

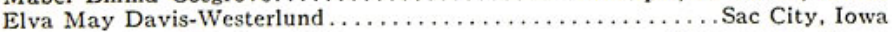

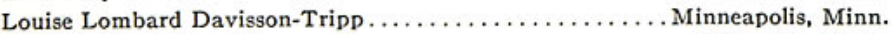

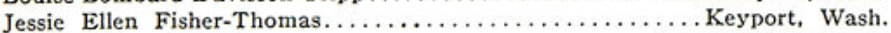

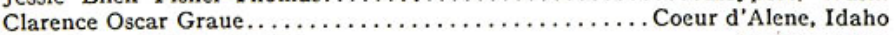
Lilah Agnes Holden-Batten..........................

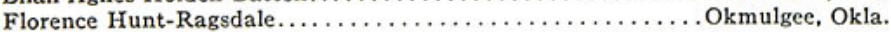
Earl Duane Jenckes...................... Dispatch, St. Paul, Minn. Clarence Eugene Johnson. . . . . . . . . . . . . . . . . Duluth, Minn. Marion Burdick Jones. . . . . . . . . . . . . . . . . . . . . . Ruth Anna McKinlay.................... Teacher, Medford, Minn. Clarice Audrey Miller-Noyes...................... Tower, Minn. Pearl Margueritte Palmer-Holley .....................Warren, Minn. John Gottfried Schmidt . . . . . . . . . . . . . . . Teacher, Omaha, Neb. William Ellison Scott ......................... South St. Paul, Minn. Ella A. Stearns............................ Principal, Jasper, Minn. Edna Alda Stewart........................ Teacher, Council Bluffs, Iowa Cassie Marie Stoddart-Johnson.................... Forest Lake, Minn. Oakley Russell Tripp................... . M. C. A., Minneapolis, Minn. 
Oscar Westerlund Minister, Sac City, Iowa

Muriel Faye Wheeler-Cockram. Ontario, Ore. Harry Merrium Willmert. . . . . . . . . . . . . Business, Hinckley, Minn. Ralph Calvin Wilson ...................... Teacher, St. Louis, Mo.

\section{Class of 1913}

Enoch Newman Bengtson. . . . . . . . . . . .

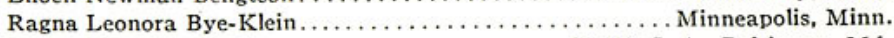
Lenna May Campbell ..................... Y. W. C. A., Baltimore, Md. Wilfrid Gladstone Campbell................. Teacher, Superior, Wis. Paul Ephraim Carlson.................... Superintendent, Elmore, Minn. Mary Genevieve Carver-Stevens . . . . . . . . . . . . . . . St. Minn. George Oliver Chase................... Superintendent, Drake, N. D. Leonard Alvin Clark ........................

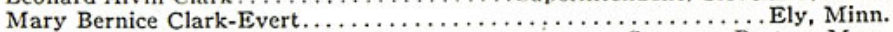

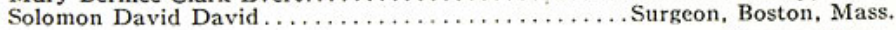
Emma Joy Frederick-Schmidt . . . . . . . . . . . . . . . Delano, Minn. William Henry Wallace Holley . . . . . . . . . . . . . . . Surgeon, Warren, Minn. Berenice Antoinette Kellogg-Hamilton.............. Pennington, N. J.

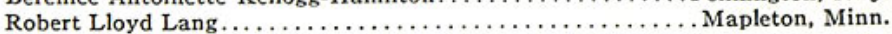

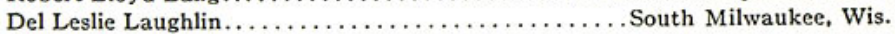

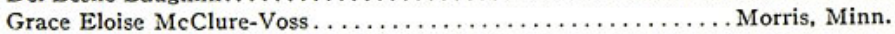
Elmer Shepard MacCourt.................. Dentist, St. Paul, Minn.

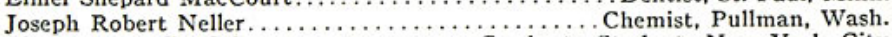

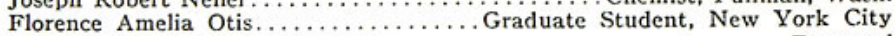
Norton Walter Peet. . . . . . . . . . . . . . . . . . . . . . . . . William Conkey Phillips................. Principal, Chippewa Falls, Wis. Edith Beatrice Pierson................ Nurse, Minnewaukan, N. D.

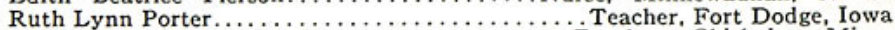
Adeline Marie Rosebrock.................... Teacher, Chisholm, Minn.

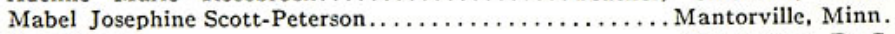

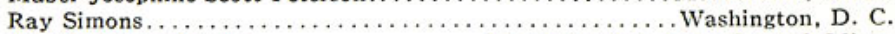
James Merton Snyder................ Superintendent, Lake Crystal, Minn. Marie Ellen Thomas..................... Teacher, Excelsior, Minn. Katie Lillian White.................. Teacher, Nashwauk, Minn. Vera May Zimbeck-Hartley ..................... Minneapolis, Minn.

\section{Class of 1914}

Carrie Ellen Alvord ................. Interpreter, Washington, D. C. Richard Harlow Anderson. . . . . . . . . . . . Superintendent, Comfrey, Minn.

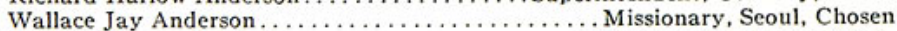
Harold Harvey Baldwin..................... Minister, St. Cloud, Minn. Hosea Greenwood Bosley . . . . . . . . . . . . . . . . . . . Harlem, Mont.

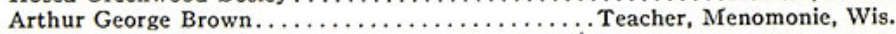

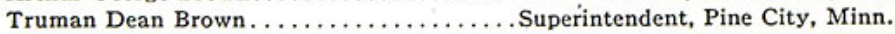
Margaret Buckbee-Greig. . . . . . . . . . . . . . . . Minneapolis, Minn.

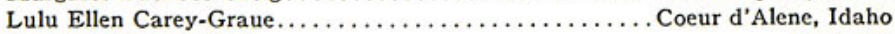
Howard Edward Clark . . . . . . . . . . . . . . . . . . . Deceased Margaret McGregor Doty................ Macalester College, St. Paul, Minn. Leslie Lisle Druley ...................... Business, Minneapolis, Minn.

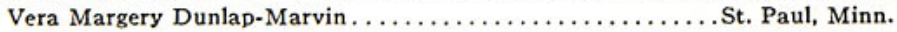




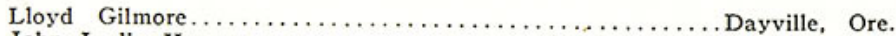

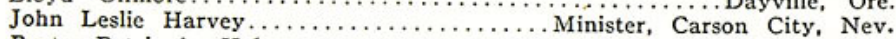
Burton Patriquine Holt.........................

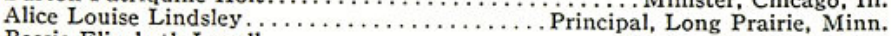
Bessie Elizabeth Lovell . . . . . . . . . . Edward Everett McCabe . . . . . . . . . . . . . . . . . . . . . . .

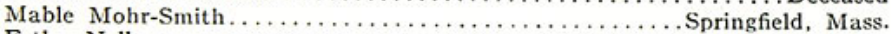
Esther Neller. . . . . . . . . . . . . . . . . . . . Teacher, Nashwauk, Minn.

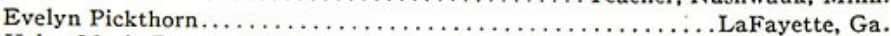
Helen Maria Prosser-Pike. . . . . . . . . . . . . . . . . . . . . . Harold Percy Roberts.................. Teacher, Appleton, Minn. Gertrude Gray Smith. ................... Teacher, St. Paul, Minn. Helen Antonia Stratte................... Librarian, Biwabik, Minn. Selma Ovidia Stratte-Watkins. ...................... Florence Adell Switzer-Hamil................. Two Harbors, Minn. Charles Albert Thomas.................... Business, St. Paul, Minn.

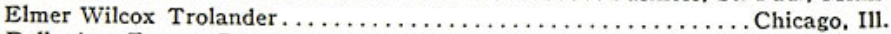

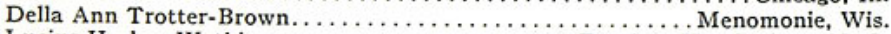
Lucius Harlow Watkins..................

\section{Class of 1915}

Clark Albin Abrahamson........................... Paul Benjamin Bremicker................ M. C. A., Minneapolis, Minn. Olive Margaret Brown-Staudenmaier............................ Minn. Mary Reid Cardle-Zabel....................... De!avan, Minn. Edward Maurice Clark. ............................ New York City

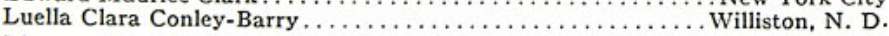

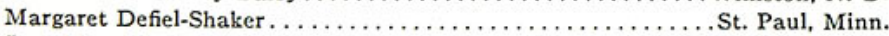
Josephine Dixon-Mangen. . . . . . . . . . . . . Gwendolyn Lotimer Eastman-Disbrow. ...................... Alcester, S. D.

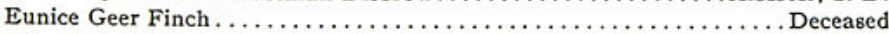
Alice Julia Flinn-Godfrey .......................... Paul, Minn.

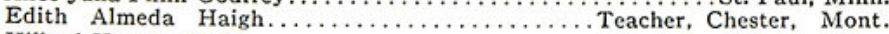
Hillard Herman Holm ................... Physician, Cokato, Minn. Catharine Deaver Lealtad . . . . . . . . . . . . . . . . . . . . Mabel Griffiths Montgomery. .................. Teacher, Seattle, Wash. John Samuel Nyquist . . . . . . . . . . . . . . . . . . . . . Homestead, Mont. Emily Helen Payne . . . . . . . . . . . . . . . . . . . . . Instructor, U. of

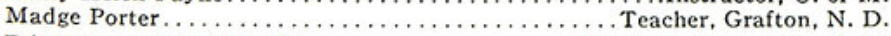
Frieda Jeannette Radusch . . . . . . . . . . . . . . Physician, Rapid City, S. D. Plato Earl Sargent .......................

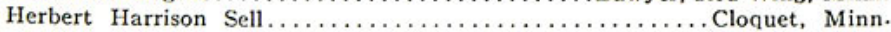
Ruth Virden Slagg. . . . . . . . . . . . . . . . . . . . . Pipestone, Minn.

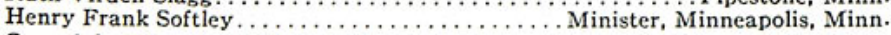
Gwendolyn Bromley Williams-Slade ................. Minneapolis, Minn. Bert Benjamin Willmert..................... Blue Earth, Minn.

\section{Class of 1916}

Arthur Glenn Adams................................. Wister, Lodi, Wis. Grace Emily Brown-Strubel . . . . . . . . . . . . . . . . . . Elma, Wash. Beryl Alberta Brownlee................... Teacher, Sheridan, Wyo. 
Gordon Lyman Brownlee.................. Business, St. Paul, Minn. George Rowland Collins............ Professor, New York U., New York City Edna Marguerite Cottrell-Schuler........................ Thomas Crocker................. Missionary, Barranquilla, Colombia, S. A.

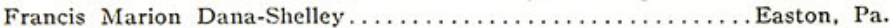

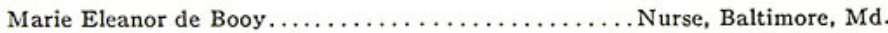
Margaret Douglass Downing............... Teacher, St. Paul, Minn. Ruth Marie Featherstone................... Teacher, Teller, Iowa

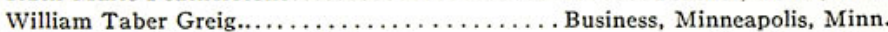
Helen Charlotte Gullikson-Willmert . . . . . . . . . . . . . . Hinckley, Minn. Vergil Homer Guthrie............................ Deceased Frank Edward Hall ........................... Little Falls, Minn. Arthur Bristow Hood ..................... Business, Rapid City, S. D. Isabelle Howard ....................... Business, Minneapolis, Minn. Howard Neff Huelster . . . . . . . . . . . . . . Business, St. Paul, Minn. Vincent Raymond Hunt................. Teacher, Bricelyn, Minn.

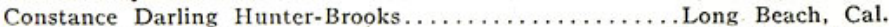

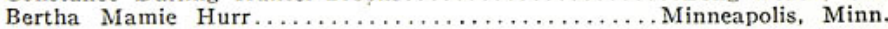
Gordon Lewis Keeley . . . . . . . . . . . . . . . . . . . . . Business, Montrose, Minn. Christopher Leo Kenny. . . . . . . . . . . . . . . . Teacher, Helena, Mont. Fred Joseph Kenny ................... Teacher, Council Bluffs, Iowa Thomas Kees Laird..................... . . . . Ioduate Student, U. of David Nathaniel Ling . . . . . . . . . . . . . . . . . . Teacher, Mankato, Minn. John Thompson McCallum............... Teacher, St. Paul, Minn. Jessie Elizabeth McClure.................. Teacher, White Bear, Minn.

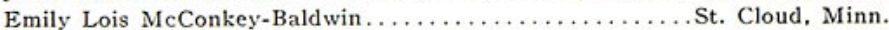
Erwin Herbert Metag. ................... Teacher, Mankato, Minn. Loana Miriam Miller-Norris ...................... Paul, Minn. Anna Seraphina Nelson........................................ Minn. Andrew Hilmer Norum . . . . . . . . . . . . . . . . Adolf Olson......................... Teacher, St. Paul, Minn. Sadie Porter........................ Teacher, Litchfield, Minn. Howard Johnson Rankin........................ Paul, Minn.

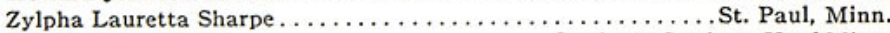
John Lyman Sheean. . . . . . . . . . . . . . Graduate Student, U. of Minn. Alice Emma Stearns..................... Teacher, St. James, Minn. Olga Constantine Terzieff-Ivanoff ................. Ann Arbor, Mich. Stella Alice Tuttle-Baird ....................... Great Falls, Mont. Vera Marie Utter-Hood ............................... William Liston Walker.................... Teacher, Sebeka, Minn.

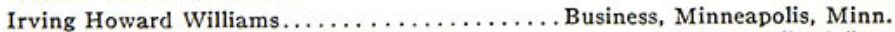

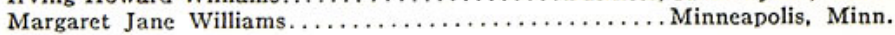

\section{Class of 1917}

Effie Alice Adams..................... Teacher, Deer Lodge, Mont.

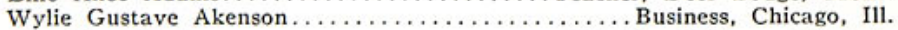
Oscar Lee Black......................... Minister, Jeffersonville, Ind. Ellen Mary Chase....................... Teacher, Sherman, S. D. Lajla Marie Dale-Gerlinger................ Thief River Falls, Minn. Gladys Somers Dallimore....................... Paul, Minn. Herbert Emil Dierenfield...................... 
Alice Muriel Everts-Easton.

Bemidji, Minn.

Emanuel Ossian Franklin

Teacher, Minneapolis, Minn.

Charles Gerlinger........................ Minister, Thief River Falls, Minn.

Wallace Graydon Gibson . . .............. S. Marine Corps, Washington, D. C.

Pauline Hayes....................... Teacher, Austin, Minn.

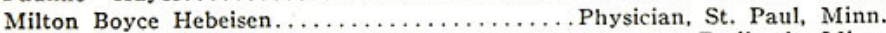

Ethelwyn Annette Hopkins-Moore.................. Faribault, Minn.

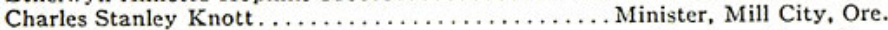

Violet Helena Knution ...................... Teacher, Ely, Minn.

John Arthur Lewis......................... Teacher, Trenton, N. J.

Ethel Marie McClure. . . . . . . . . . . . . . . . . . . . . . . Chicago, Ill.

Swan William Mattson............................ Minister, Poskin, Wis.

Evelyn Bradbury Page.......................... St. Paul, Minn.

Harriet Phillips . . . . . . . . . . . . . . . . . . . . Teacher, Stillwater, Minn.

Esperanza Reina......................... W. C. A., El Paso, Texas

Joseph Howard Rhoads..................... Teacher, Rochester, Minn.

Allen John Robertson.................... Business, Minneapolis, Minn.

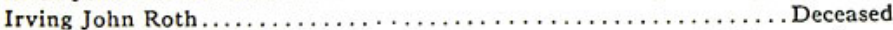

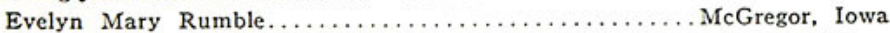

Esther Atta Schumann-Brownlee. . . . . . . . . . . . . . . St. Paul, Minn.

Gertrude Simons....................... Teacher, Cheyenne, Wyo.

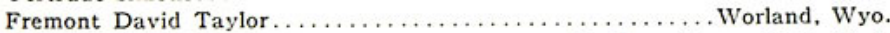

Anna Marie Wagner................... Teacher, Asbury Park, N. J. Lucille Anna Wilkerson. ..................... Graduate Student, U. of Minn.

Clarence Charles Willmert.............. Business, Minneapolis, Minn.

\section{Class of 1918}

Donald Leslie Augustine . . . . . . . . . Instructor, Johns Hopkins University Leonard Bedient Brabec.................... Teacher, Memphis, Tenn. Lucia Rebecka Brown..................... Teacher, Cloquet, Minn. Ella Isabelle Clapp-Peake........................ Eufaula, Ala. Walfred Danielson...................... Teacher, St. Paul, Minn.

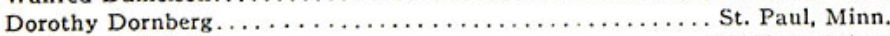

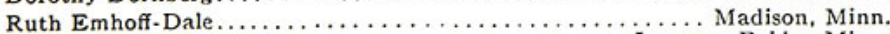
John Kenneth Erickson................................... Fulda, Minn. Erling Eriksen .................... Teacher, Stewartville, Minn.

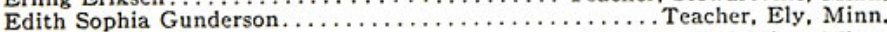
Margaret Lila Hammond . ................ Teacher, Red Wing, Minn. Victor Arnold Heed . . . . . . . . . . . . . . . . . . . . Teacher, Silver Lake, Minn. James Kydd Hilyard............ Principal, Peabody Academy, Troy, N. C. Frank Orville Holmes........................ Minister, Cambridge, Mass.

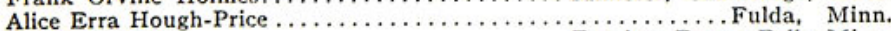
Esther Jerabek........................ Teacher, Fergus Falls, Minn. Ethel Marie Leck-Stoltzfus. . . . . . . . . . . . . . . . . . Beirut, Eugenie Marie Legault-Taylor ............................ Worland, Wyo. Marian Louise Lesher..................... Principal, Barnesville, Minn.

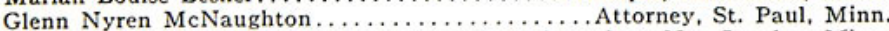
Howard Hope McNiven............. Superintendent, New London, Minn.

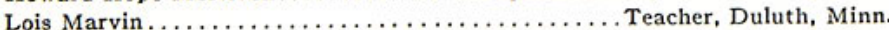
Ernest Gustav Norstrom.................... Teacher, Crookston, Minn. John Alexander Patterson.............. Superintendent, Moose Lake, Minn. Hazel Louisa Roche......................... Teacher, Anoka, Minn. 
Helen Isabel Sivertson. . . . . . . . . . . . . . . Teacher, Fergus Falls, Minn. Myrtle Dorothy Steen.................... Teacher, Kerkhoven, Minn. Miriam Winifred Wallace-Scanlon................. San Francisco, Cal. Ruth Azalia Webster............................ Paul, Minn. Nancy Olivia Wick.................... Teacher, Worthington, Minn. Amelia Wolf-Stemen Millersport, Ohio

\section{Class of 1919}

Leila Arvilla Atcherson. .................... Teacher, Buffalo, Minn. Dorothy Badger-Keeley................................. Minn. Bertha Blair........................ W. C. A., Kalamazoo, Mich.

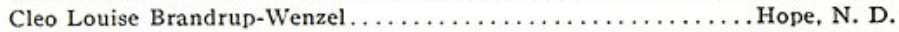
Hellen Clark-Friese. . . . . . . . . . . . . . . . . . . . . . . . . . . Florence Anna Defiel. ................ Downer College, Milwaukee, Wis. Paula Doermann.................... Teacher, Minneapolis, Minn. Muriel Emily Carr Eastman................... Teacher, Milaca, Minn. Lucile Grace Farrell-Anderson . . . . . . . . . Melvin Louis Gundlach.... . . . . . . . . . . . . . Superintendent, Stephen, Minn. Anna Estelle Hammerlun..................... Teacher, Adams, Minn. Tillie Hansen . . . . . . . . . . . . . . . . . . . . . Teacher, Willmar, Minn. Hulda Hanson. . . . . . . . . . . . . . . . . Principal, Red Lake Falls, Minn.

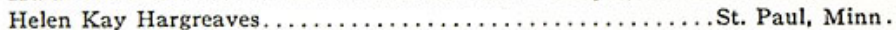
Wesley Arthur Kohl .................. Principal, Buffalo Lake, Minn. Raymond Horace Landon..................... Minneapolis, Minn. Amy Marie Le Vesconte.................. Graduate Student, U. of Minn. Alice Vivian Little .................... Architect, Minneapolis, Minn. Margaret McLeod-Crocker................... Barranquilla, Colombia, S. A. Helen Willina McRae.................... Teacher, Faribault, Minn. Marion Gertrude Reader-Colby ...................... Minneapolis, Minn. Gladys Harriett Reutiman................. Teacher, Honolulu, T. H.

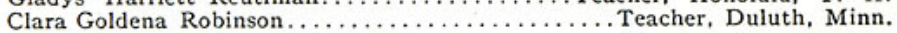
Ada Rose Stalker ......................... Teacher, Duluth, Minn. Helen Strachan-Clark . . . . . . . . . . . . . . . . . . . . Rockville, Minn. Helene May Thomas........................ Teacher, Oakes, N. D.

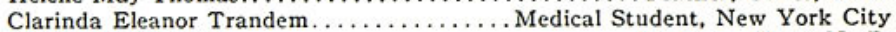

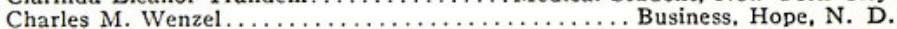
Margaret Eliza Wharry-Winford . . . . . . . .

\section{Class of 1920}

Julian Francis Anderson . . . . . . . . . . . . . . . . . . . . . .

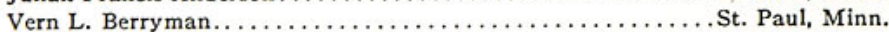
Marion Catherine Cardle................ Teacher, Mountain Iron, Minn.

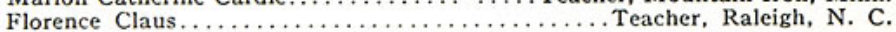
May Charlotte Coleman................. Teacher, Elk River, Minn. Marion Armerel Conger.................... Teacher, Grand Rapids, Minn. Orin Montgomery Corey.................... Teacher, Sandwich, Wis. Joseph Douglas Crane........................... Paul, Minn. Constance Cronhardt............................. Pt. Paul, Minn.

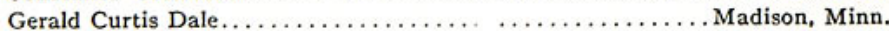
Alice Grace Davidson. . . . . . . . . . . . . . . . Teacher, St. Paul, Minn. Marjorie Dornberg. ................... Teacher, Le Sueur, Minn. 
Lucile Jeannette Erickson-Groskientz.............. Lake Wilson, Minn. Alice Mary Fletcher-Sprague............................. Ethel Alice Fletcher. . . . . . . . . . . . . . . . . . . . . Teacher, Herman, Minn. Lillian Taylor Flitch.....................

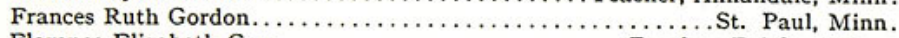
Florence Elizabeth Gow................... Ralph Everett Greig. ..................... Business, St. Paul, Minn. Roy Alfred Greig. .................... Principal, Lamberton, Minn. Hazel Mary Griffith................... Teacher, Hallock, Minn.

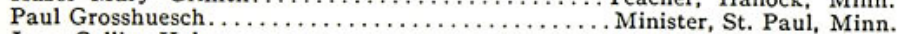
Jesse Collins Hales........................... Teacher, Gardner, Mass. Louise Elizabeth Hall. .................. Teacher, Onamia, Minn.

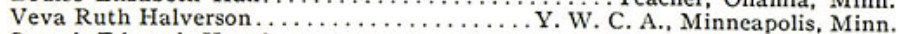

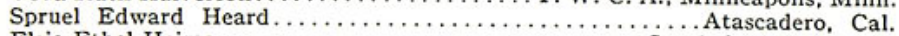
Elsie Ethel Heimer. ............................... Ruth Anna Helweg. ....................... Claude Douglas Holzinger................ Principal, Greenbush, Minn. Ruth Hoxie. ........................ Teacher, Duluth, Minn.

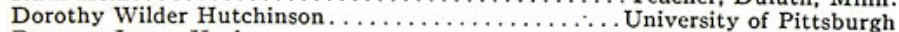

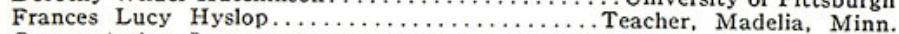
George Arthur Jensen................. Teacher, Minneapolis, Minn. Linnea Margaret Johnson................ Teacher, Bemidji, Minn. Merle Constance Johnson-Robinson.................. Oelwein, Iowa

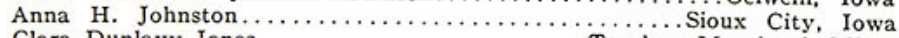

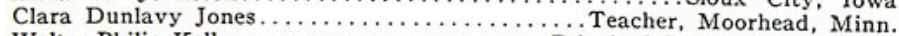
Walter Philip Keller..................... Principal, Lake Crystal, Minn. Adolf Kongelf .......................... Carrie Louise Krugmeier-Christensen................ Paul, Minn. Gertrude Helene Krugmeier. . . . . . . . . . . . .

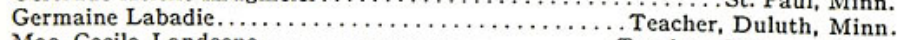
Mae Cecile Landeene.................... Teacher, Warren, Minn.

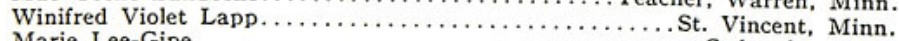

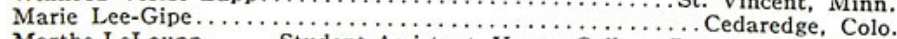
Marthe LeLoupp.......... Student Assistant, Vassar College, Poughkeepsie, N. Y.

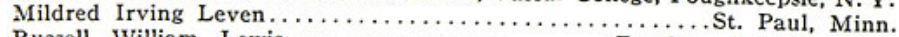
Russell William Lewis.................................. Tripoli, Syria

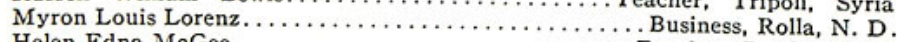

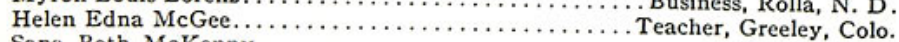

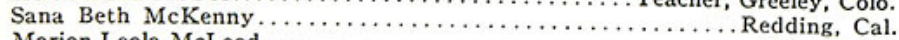
Marion Leola McLeod . . . . . . . . . . . . . . . . . . . . . . . . . .

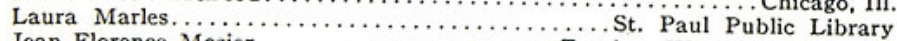

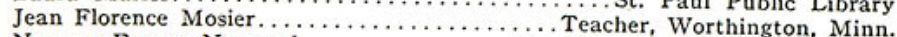
Norman Eugene Nygaard..................... Violet May Olson.$\ldots \ldots \ldots \ldots \ldots \ldots \ldots \ldots \ldots$ Teacher, Watertown, S. D.

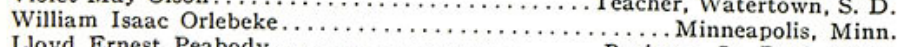

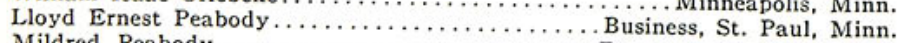

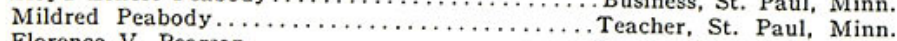

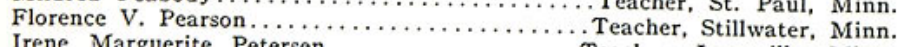
Irene Marguerite Petersen................. Teacher, Janesville, Minn. Ruth Amelia Rost.......................... William John Shogren......................

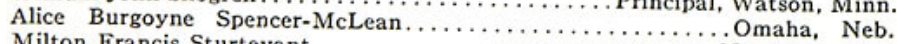

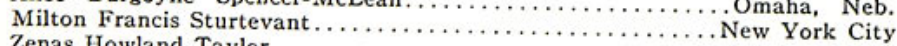

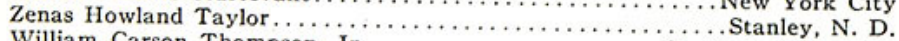

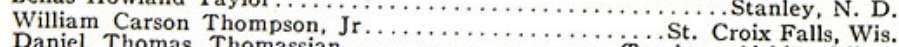
Daniel Thomas Thomassian......................... Chester Martin Tobin..................

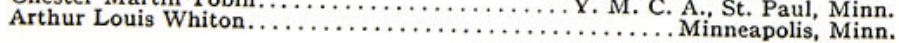




\section{Class of 1921}

Alric Anderson........................ Saw Student, U. of Minn. Grace Bross-Ringold . . . . . . . . . . . . . . . . . . . . . . . . Leslie Willis Brown................. Teacher, Elk River, Minn. Alvin Clayton Busse.................. Yew York University, N. Y.

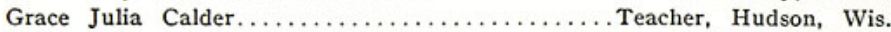
William Gibson Claffy ................. Business, So. St. Paul, Minn. Marguerite Craig....................... Teacher, Madison, Minn.

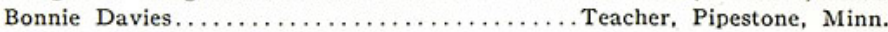
William Tammel DeBoer................................. S. D. Esther Deakin Donnelly................. Teacher, Browerville, Minn. Lenice Evelyn Felthous......................... Paul, Minn. John Louis Ferry............................... Sask. Victor Karl Funk. ........................ Medical Student, U. of Minn. Robert Francis Gale. ............ Theological Student, Princeton, N. J. Elsie Genevieve Gerlach-McNutt............. Two Harbors, Minn.

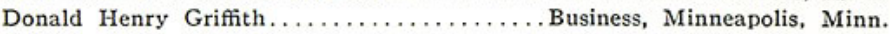
Grace Marie Guilford . . . . . . . . . . . . . . Instructor, Macalester College Marion Ethel Haigh . . . . . . . . . . . . . Graduate Student, U. of Minn. Doris Halverson. ................... Teacher, Redwood Falls, Minn. Willis Blackford Hazleton.................. Business, Duluth, Minn. Guy Louis Hill .................. Theological Student, Philadelphia, Pa. Myrtle Genevieve Hynes................... Teacher, Big Sandy, Mont. Ruth Gladys Isker................... Instructor, Macalester College Florence Wilhelmina Johnson-Nygaard................ Omaha, Neb. Frederick Ben Johnson. ........ Teacher, Agricultural College, St. Paul, Minn. Helmer Gerhardt Johnson................ Teacher, Galesburg, N. D. Frances Helen Krenger-Emmett. . . . . . . . . . . . . Moose Lake, Minn. Lawrence Joseph Legault.................. Teacher, Ravinia, S. D. James D. Lightfoot............................ Raymond Delos Lilley..................................... Ill. Helen Frances McLean-Rock.................... Minneapolis, Minn.

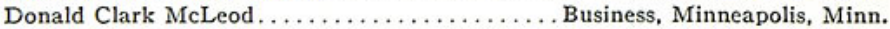
Jessie Norris Mayo ....................... Teacher, Anoka, Minn.

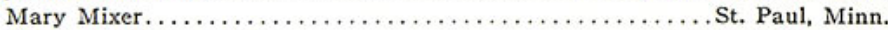
Helen Arabella Newell. ................................ Minn. Pearl Isabella Nisbet.................. Teacher, Forest Lake, Minn. Edward Oakley Paden.................... Teacher, Mankato, Minn. Lillian Marie Paulson. ........... Y. W. C. A. Secretary, Hibbing, Minn. Ione Vilona Pickle................... Teacher, Redwood Falls, Minn. Ellen Marie Pope-Busse......................... Yow City

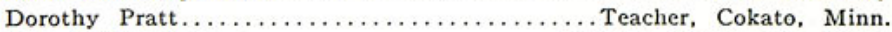

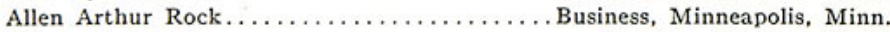
Elizabeth Schade...................... Teacher, Midland, S. D.

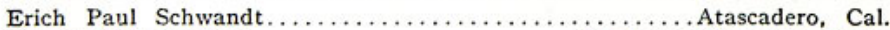
George Eddy Scotton.................... Teacher, Albert Lea, Minn. Ruth Marjorie Swift................. Teacher, Caledonia, Minn. Florabel Elenor Wickett-Claffy ....................... Paul, Minn. Vera Emerson Wilcox............ Y. W. C. A. Secretary, Minneapolis, Minn. Winifred Wilkerson................... Teacher, Stillwater, Minn.

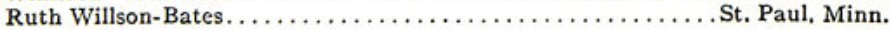




\section{Class of 1922}

Lillian Grace Anderson................. Teacher, New London, Minn.

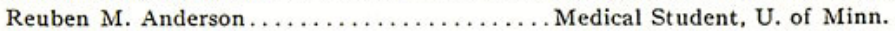
Rufus Alonzo Barackman. ................ Teacher, New Prague, Minn. Percy Judson Bevis............................. Duluth, Minn.

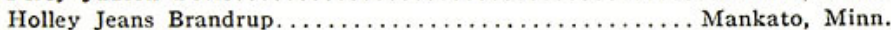

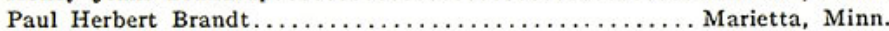
Jeanne Catherine Brown.................. Teacher, Milford, Iowa Leland Davidson Case................... Teacher, St. Cloud, Minn.

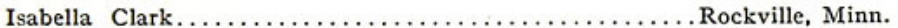
Jacob Cornils .............................. Paul, Minn. Joyce Edna Dauwalter................... Teacher, Peterson, Minn. Emil Joakim Fogelberg.................. Eugenio M. Fonbuena . . . . . . . . . . . . . Graduate Student, U. of Minn. Elmer William Fondell.................... Teacher, Tekoa, Wash.

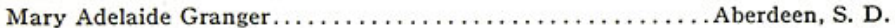
Ward Marshall Gray . . . . . . . . . . . . . . . Wilton Gundlach..................... Teacher, Stephen, Minn. Nina Purcell Gunnison................... Instructor, Macalester College Stuart Wesley Hannah. . . . . . . . . . . . . . . . . . . Fisher, Minn. Bernice Goldia Horton................... Teacher, Frederic, Wis. Myrtle Victoria House.................. Teacher, Cass Lake, Minn. Alice Lois James........................ Teacher, Hecla, S. D. Richard M. James..................... Teacher, Circle, Mont. Olive Cecelia Johnson-Tanquist................... Alexandria, Minn.

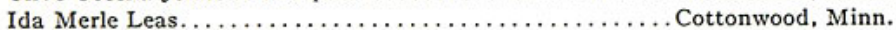
Dewey John Arthur Lindquist. . . . . . . . . . . . Teacher, Wayzata, Minn. Hazel Vivian Lundsten.................. Teacher, St. Paul, Minn. Margarette Ralston McNaughton........... Teacher, Sleepy Eye, Minn.

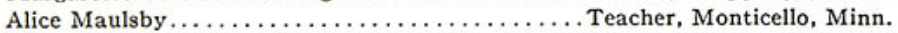
Bertha Louise Medcalf. .................. Teacher, Kasson, Minn.

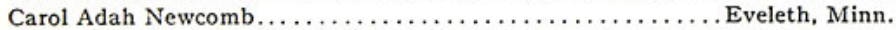
Grace Violet Nystrom. . . . . . . . . . . . . . . . . Teacher, Sarles, N. D. Edith Marie Olson..................... Teacher, Slayton, Minn. Clarence M. Purvis............................. Tracy, Minn. Margaret Irene Rappe . . . . . . . . . . . . . . . . . Teacher, Slayton, Minn. Helen Frances Reed . . . . . . . . . . . . . . . . . . . . . . . . . . Arline Osgood Sander . . . . . . . . . . . . . . . . . . . . Teacher, Philip, S. D. Anna Belle Scidmore. . . . . . . . . . . . . . . . . . . . . . . Teacher, Clark, S. D. Eleanor Florence Spates. . . . . . . . . . . . . Teacher, Farmington, Minn. Lucile Strachan . . . . . . . . . . . . . . . . . . . . . . Duluth, Minn. Harlan Edgar Tripp. .................... Superintendent, Hawley, Minn. Leslie Elliott Tripp.................... Superintendent, Rushmore, Minn. Ruth Morse Upton . . . . . . . . . . . . . . . . . . . . . . . . . . William Michael Wagner................ Graduate Student, Harvard U. Marshall Franz Westerlund.............. Teacher, Carlton, Minn. 


\title{
Alumni of the Conservatory of Music
}

\author{
Class of 1900
}

Mrs. Maud Taylor-Hansen Minneapolis, Minn.

\section{Class of 1901}

Millicent Viola Mahlum-Kelts . Columbus, Mont.

\section{Class of 1905}

Grace Taylor-Franklin Emerado, N. D. Mrs. W. H. Amos Parkdale, Ore.

\section{Class of 1906}

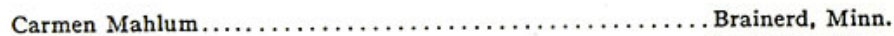

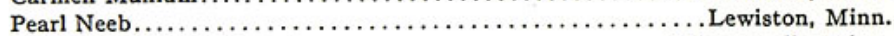

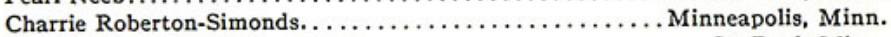
Mildred Gretchen Phillips-Kindy....................... Paul, Minn. Paul H. Th. Rusterholz ......................... Paul, Minn.

\section{Class of 1907}

Gyda Hansen.

St. Paul, Minn.

Richard U. Jones.

St. Paul, Minn.

\section{Class of 1908}

Ethel Erkenbrack-Funk

Minneapolis, Minn.

Ada Nash-Patterson. Edgerton, Minn.

Gladys Neff Neillsville, Wis. Minnie Tullar-Doty St. Paul, Minn. Clara Odenwald-Abbet Minneapolis, Minn.

\section{Class of 1909}

Lorraine Vern Miller La Moure, N. D.

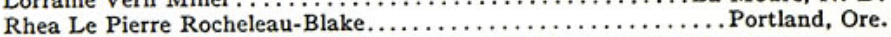
Anna May Woodworth-Lunn...................... Paul, Minn.

\section{Class of 1910}

Ardelia Bisbee Madelia, Minn. Mildred C. Corliss. . . . . . . . . . . . . . . . . . . . . . Portland, Ore.

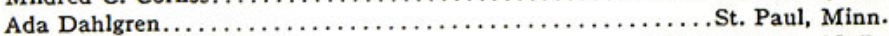
Lillian Hall . . . . . . . . . . . . . . . . . . . . . . . . . . Estelle Spayde ................................... 


\section{Class of 1911}

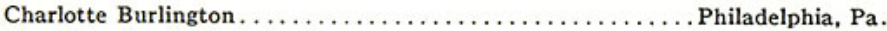
Elva May Davis-Westerlund ................... Iowa Falls, Iowa Katherine Gamble-Baskerville $\ldots \ldots \ldots \ldots \ldots \ldots \ldots \ldots \ldots \ldots \ldots \ldots \ldots \ldots \ldots$ Langlois, Ore. Myrtha Marie Gunderson...................... Paul, Minn. Ethel Haggard-Stewart ......................... Pt. Paul, Minn. Stella Wilhelmina Heger-Wilson................... Cloud, Minn.

\section{Class of 1912}

Mary Genevieve Carver-Stevens.................... St. Paul, Minn.

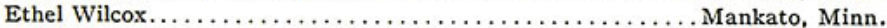

Lottie M. Olson-Taralseth .......................Warren, Minn.

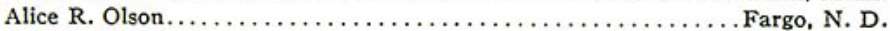

Louise Appel-Kuck. .......................... Paul, Minn.

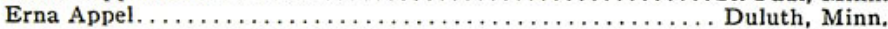

\section{Class of 1913}

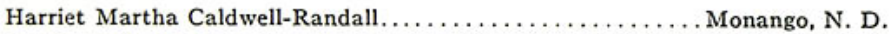

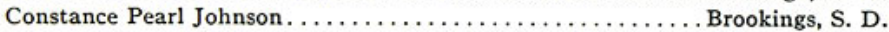
Alice Elvira Larson-Sivertson. ................... Alexandria, Minn. Geneva Samson-Dinwoodie....................... Pt. Paul, Minn. Ethel May Stewart............................ Paul, Minn. Stella Alice Tuttle-Baird...................... Great Falls, Mont.

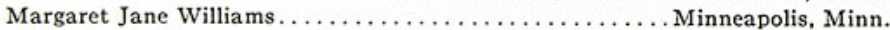

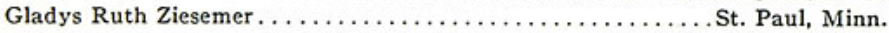

\section{Class of 1914}

Jean Adie-Hullsiek (Bachelor of Music) ................... Pt. Paul, Minn. Harriet Caldwell-Randall............................. Mabel Reed..................................... Pt. Paul, Minn.

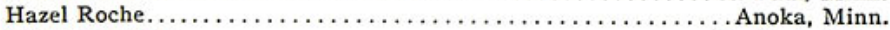
Evelyn Rumble............................... Paul, Minn.

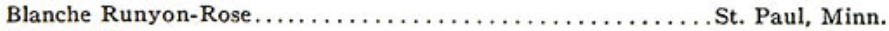

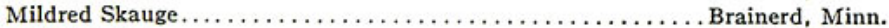

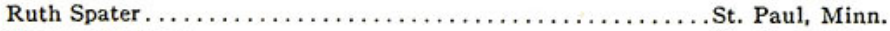
Clarence Vokoun .................................. Paul, Minn. Amelia Wolf-Stemen. . . . . . . . . . . . . . . . . . . . . . . . . Vernie Wolfsberg. . . . . . . . . . . . . . . . . . . . . . . . . St. Paul, Minn.

\section{Class of 1915}

Albina Agnes Minar. . . . . . . . . . . . . . . . . . . Browerville, Minn. Frank C. L. Minar............................. Browerville, Minn.

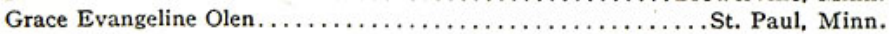

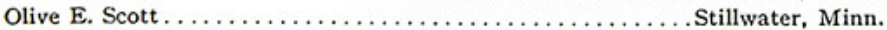

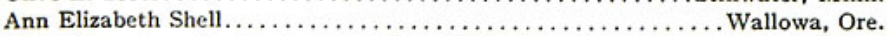
Ethel Genevieve Tamborino ....................... St. Paul, Minn. Grace Marie Waddell ................................ Paul, Minn. Maude Julia Wanzer............................ Charleston, W. 


\section{Class of 1916}

Lilah Bellingham-Johnston Lordsburg, N. M.

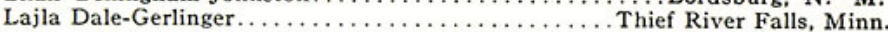

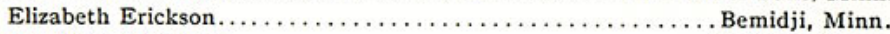

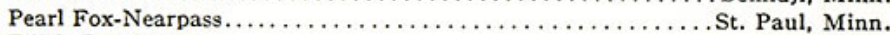
Edith Gunderson................................ Ely, Minn.

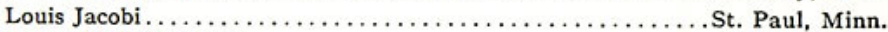
Grace O'Neale-Strom . . . . . . . . . . . . . . . . . . . Jackson, Minn.

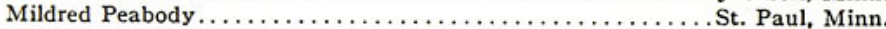
Harriet Pierpont-Smith. . . . . . . . . . . . . . . . . . . . . Bruce, Wis. Evelyn Rumble (Bachelor of Music) ................. St. Paul, Minn.

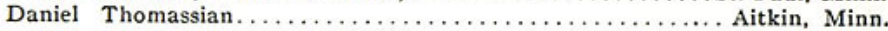

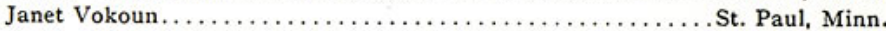

\section{Class of 1917}

Leonard Brabec................................... Lucile Farrell-Anderson . . . . . . . . . . . . . . . . . . Lakefield, Minn.

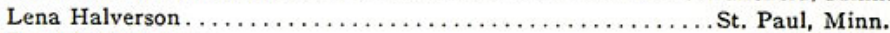

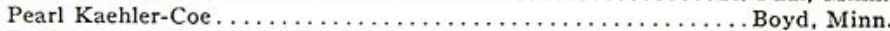

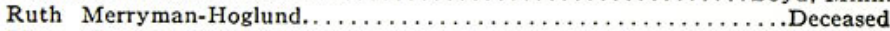

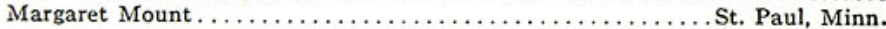
Harriet Phillips . . . . . . . . . Agnes Wunderlich. St. Paul, Minn.

\section{Class of 1918}

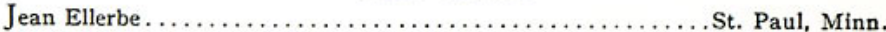
Lucile Farrell-Anderson (Bachelor of Music) ............. Lakefield, Minn.

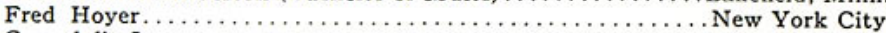
Gwendolin Lomnes...................................... Hawaii Laura Lynch. ................................ Orr, N. D.

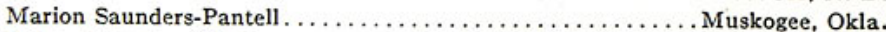
Helen Strachan-Clark........................ Rockville, Minn. Margaret Wharry-Winford . . . . . . . . . . . . . . . . . Virginia, Minn.

\section{Class of 1919}

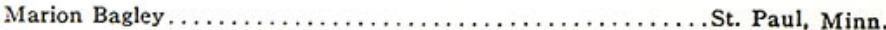

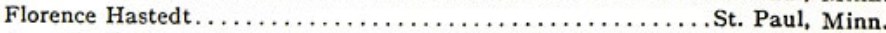

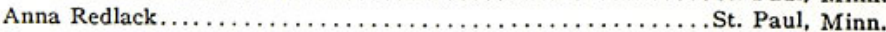
Emma Schroeder............................... Paul, Minn. Doris Utter-Smith............................

Class of 1920

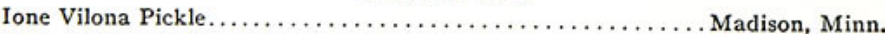
Ruth Marjorie Swift. . . . . . . . . . . . . .

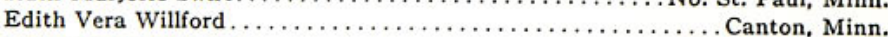
Lydia Emily Wrbitzky ..............................

\section{Class of 1921}

Ruth Lindbloom-Negaard.................... Stillwater, Minn. Alice Maulsby ......................................

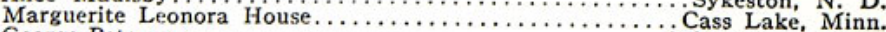
George Peterson...................................... 
Class of 1922

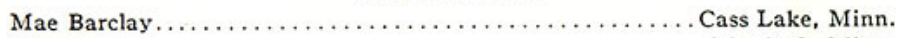

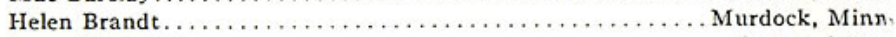
Joyce Dauwalter . . . . . . . . . . . . . . . . . . . . . . . . . .

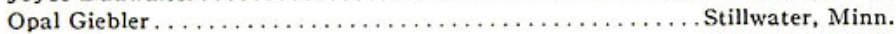

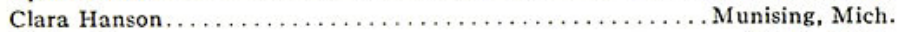

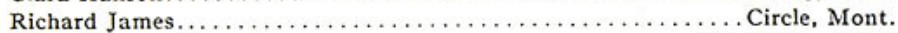
Olive Johnson-Tanquist. . . . . . . . . . . . . . . . . .

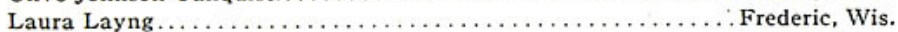
Julia Rost . . . . . . . . . . . . . . . . . . . . . . . . . . 


\section{Roll of Students}

\section{Senior Class}

Saturnino Abasolo

Philippine Islands

David August Anderson . . . . . . . . . . . . . . . . . . . .

Ella Louise Anderson. . . . . . . . . . . . . . . . . . . .

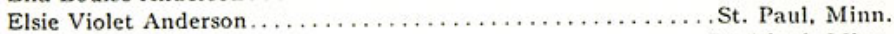

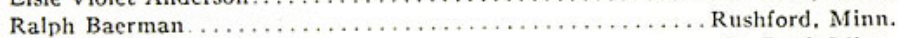

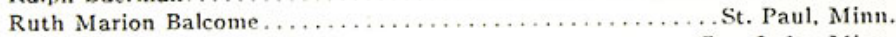

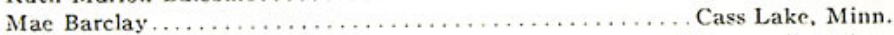

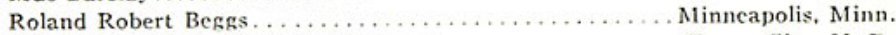

Albert Arnold Beltman ........................ Tower City, N. D.

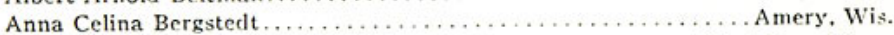

Paul Adolph Bjelland.... . . . . . . . . . . . . . . . Albert Lea, Minn.

Helen Christine Brandt. . . . . . . . . . . . . . . . . . . .

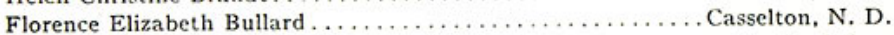

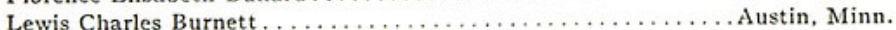

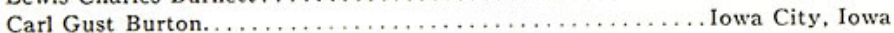

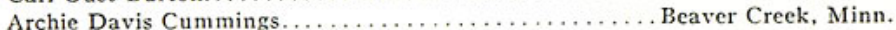

Margaret Custer. .......................... Howard Lake, Minn.

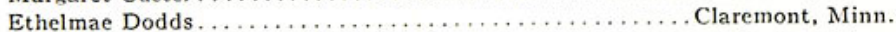

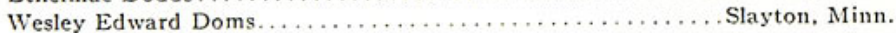

Ella Ruth Eide. . . . . . . . . . . . . . . . . . . . . Rushmore, Minn.

Miriam Emhoff. ........................... York, Nebraska

Nellie Henrietta Erickson...................... Minneapolis, Minn.

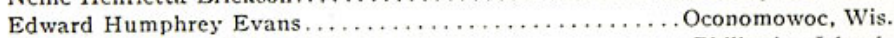

Dedimo Maglaya Fonbuena ................... Philippine Islands

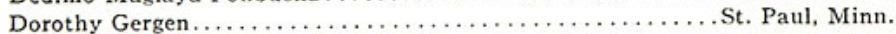

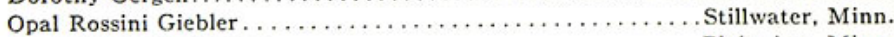

Marjorie Lucille Greive....................... Plainview, Minn.

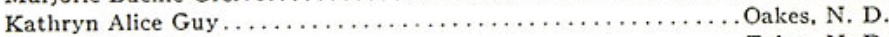

Harold Curtis Hand . . . . . . . . . . . . . . . . . . . . . . . . . .

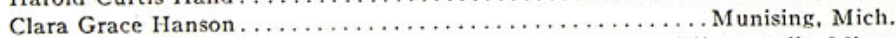

Walter Samuel Hauser. . . . . . . . . . . . . . . . . Minneapolis, Minn.

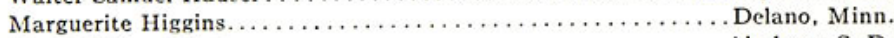

Henry Richard Holman. . . . . . . . . . . . . . . . . Ahnberg, S. D.

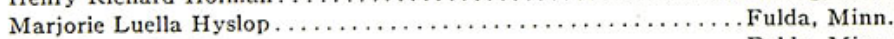

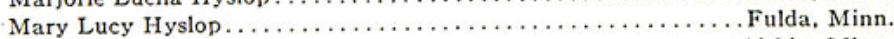

Victor Elmer Jacobson . . . . . . . . . . . . . . . . . . . Aitkin, Minn.

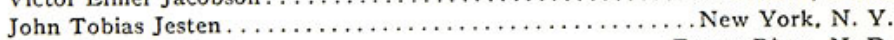

Jane Myretta Johnston....................... Forest River, N. D.

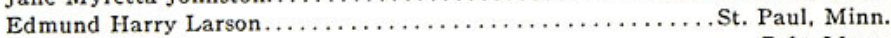

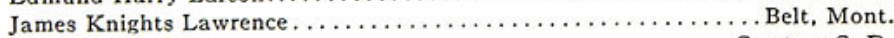

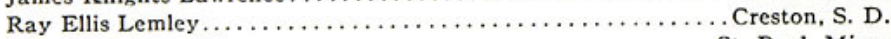

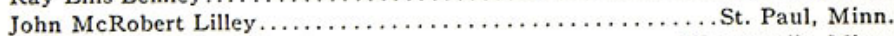

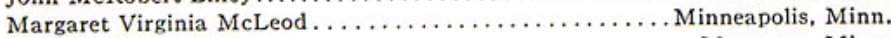

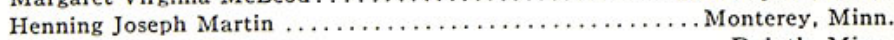

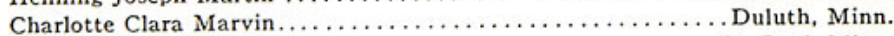

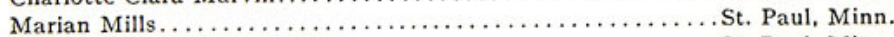

Leopold William Moench...................... Paul, Minn.

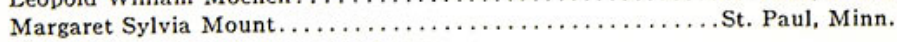


Pearl Catherine Murray........................ Paul, Minn. Ruth Victoria Nelson........................ Minneapolis, Minn. Elmer Edward Nyberg......................... Paul, Minn.

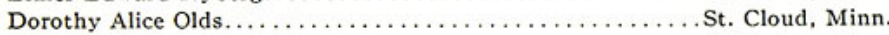

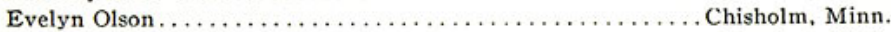

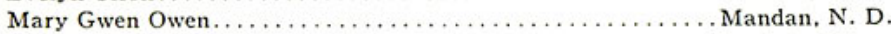

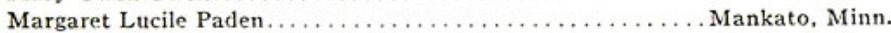
Hector Perrier. . . . . . . . . . . . . . . . . . . . . . . . . . .

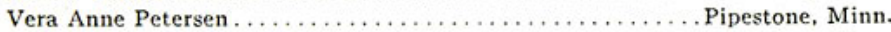

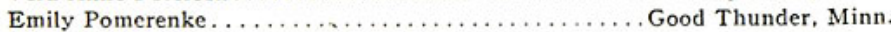
Hervey Morris Richardson. . . . . . . . . . . . . . . . . Morris, Minn. Robert Edwin Rock. .............................. Paul, Minn. Frank Maxwell Scott . . . . . . . . . . . . . . . . . . . . . Paul. Minn. Winston Blackburn Smythe .......................... Buffalo, Minn.

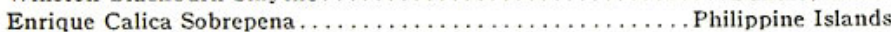
Gilbert Miller Stevenson. ..................... Duluth, Minn.

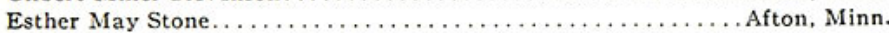
Miriam Jeannette Sylvester.......................... Olivia, Minn.

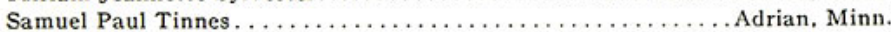
Joseph Herman Underdahl. . . . . . . . . . . . . . . . . . . Frost, Minn.

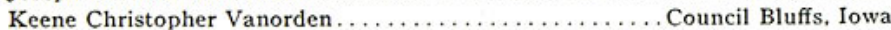
Floyd Luchsinger Wentworth...........................

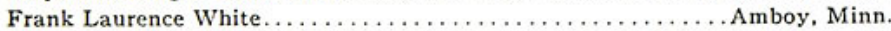

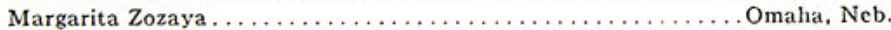

\section{Junior Class}

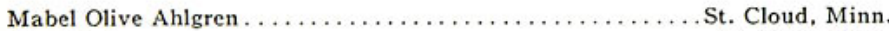

Enor Anderson . . . . . . . . . . . . . . . . .

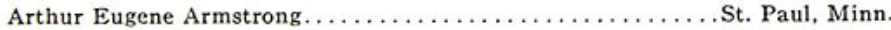

Lois Adelaide Avery . . . . . . . . . . . . . . . . . . . . . . . . .

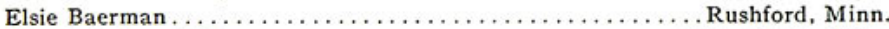

Ernest Arthur Bailey.......................Winnebago, Minn.

Ruth Kathleen Barackman..................... Duluth, Minn.

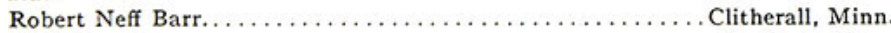

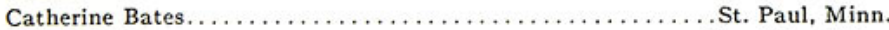

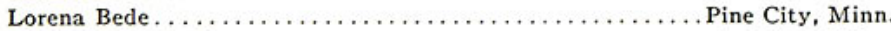

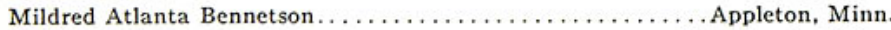

Marian Eloise Benson . . . . . . . . . . . . . . . . . Minneapolis, Minn.

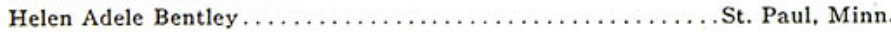

Martha Elizabeth Bolt ........................ Paul, Minn.

Roscoe Lyle Bonham . ...................... Paul, Minn.

Adeline Elizabeth Borgeson ..................... Minneapolis, Minn.

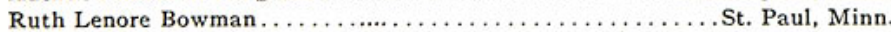

Elbert Parker Boyden. . . . . . . . . . . . . . . . . . . . . . . . .

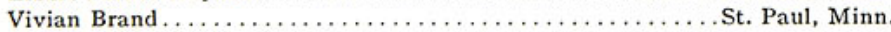

Hilma Adele Brunius . . . . . . . . . . . . . . . . . . . . . Carver, Minn.

Theodore Roosevelt Burges.................... Clara City, Minn.

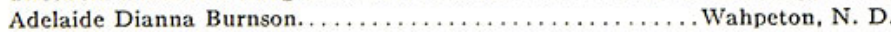

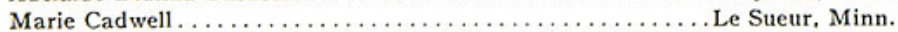

Emil Theodore Carlson ................................ Minn. 
Paul Theodore William Carlson ................... Minneapolis, Minn.

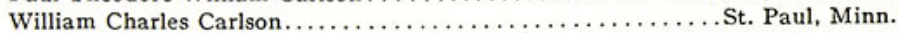

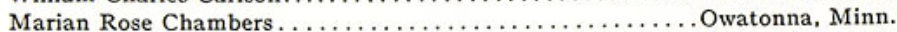

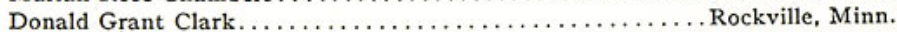

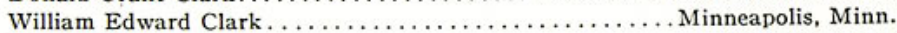

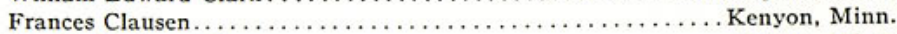

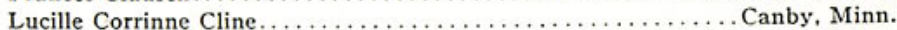
Eulala Colyn $\ldots \ldots \ldots \ldots \ldots \ldots \ldots \ldots \ldots \ldots \ldots \ldots \ldots \ldots \ldots \ldots \ldots \ldots \ldots$ Stratford, Wis. Lenora Esther Deters............................ Paul, Minn. James Ira Dickson . . . . . . . . . . . . . . . . . . . . . . . . Dalzell, S. D.

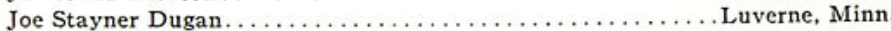
Nathaniel Carl Edwall........................... Paul, Minn. Ruth Lolita Empey . . . . . . . . . . . . . . . . . Farmington, Minn.

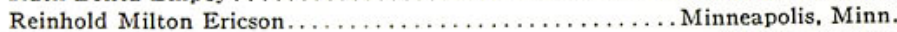
Erik Harold Ericsson. . . . . . . . . . . . . . . . . . . . . . . Kolsva, Sweden Colburn Charles Fifield. . . . . . . . . . . . . . . . . . Minneapolis, Minn.

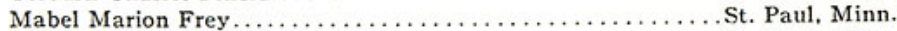

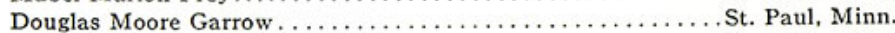
Helen Louise Gibbs............................. Paul, Minn.

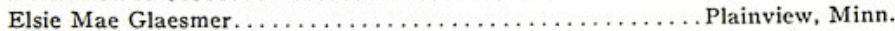

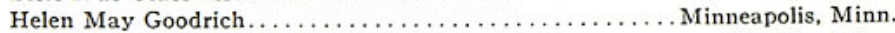
Miriam Elizabeth Gordon. ...................... Virginia, Minn.

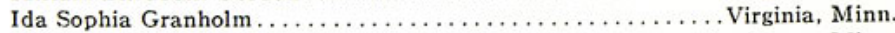
Lester Marion Greig. . . . . . . . . . . . . . . . . . . . Rushmore, Minn.

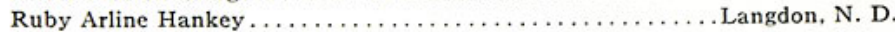

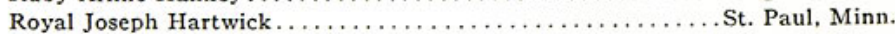
Robert Fayette Haskin. . . . . . . . . . . . . . . . . . Philbrook, Minn.

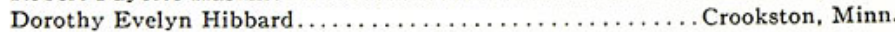
Jane Stuart Howard . . . . . . . . . . . . . . . . . . . . Lucille Marguerite Hudson . . . . . . . . . . . . . . . . . Correll, Minn. Constance Helen Humphrey . . . . . . . . . . . . . . . . . . St. Paul, Minn.

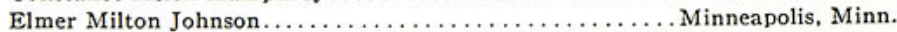

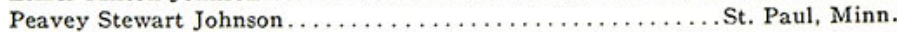

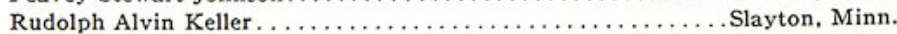
Katherine Kennedy . . . . . . . . . . . . . . . . . . . . . . St. Paul, Minn.

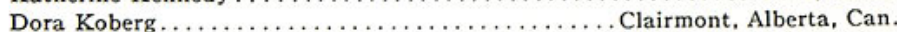
George Oakley Leck. ............................. Buffalo, Minn. Lillian Ruth LeVesconte. ......................... Prior Lake, Minn.

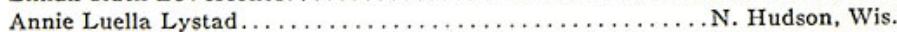
Harriet Patricia McComb........................ Paul, Minn.

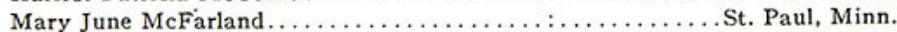
Philander Gilbert McKeown . . . . . . . . . . . . . . . . . . Alexander James McLean. . . . . . . . . . . . . . . . . . . Langdon, N. D. Vida Jean McNaughton...................... Redwood Falls, Minn. Margaret Florence McPhee....................... Pt. Paul, Minn. Albin Oscar Mark . . . . . . . . . . . . . . . . . . . . . . . . McVille, N. D. Ezra Meckel .................................. Wabasso, Minn. Silas Archie Meckel . . . . . . . . . . . . . . . . . . . . . Wabasso, Minn. Velva Belle Minty................................ Paul, Minn.

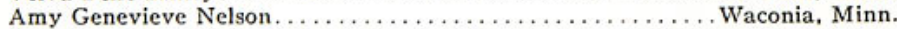
Florence Kathleen Nelson. . . . . . . . . . . . . . . . . . . . Mora, Minn. Russell Perry Nelson. .......................... Minneapolis, Minn. 


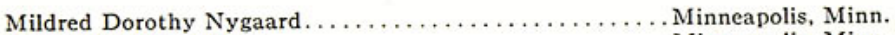

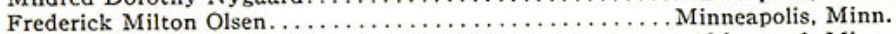

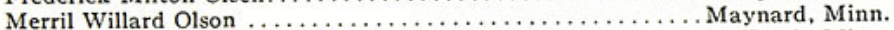

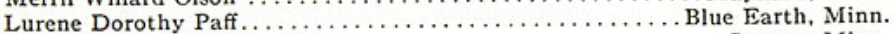

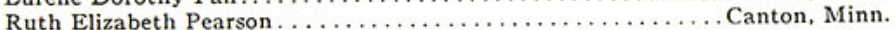
Meryl Josephine Pederson. ........................... Paul, Minn.

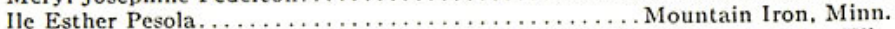

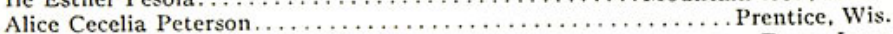

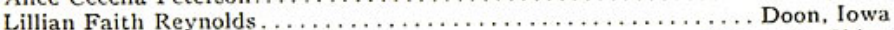
Eric Arthur Rinell. . . . . . . . . . . . . . . . . . . . . . . Shantung. China Russell Lincoln Robinson. .........................Warren, Minn. Ilma Rosalie Ruohmaki. . . . . . . . . . . . . . . . . . . Chisholm, Minn.

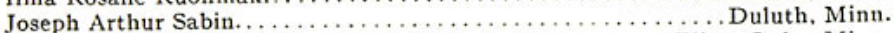
Elaine Cecile Schaeffer......................... Elbow Lake, Minn. Adolph Albert Edward Schaumburg. . . . . . . . . . . . Buffalo Lake. Minn. Gladys Leonora Scheiber......................... St. Paul, Minn. Susan Sarah Schock. . . . . . . . . . . . . . . . . . . . . . . . Jackson, Minn. Pearl Jane Shaw ................................. Robbinsdale, Minn. Helen Marguerite Sherman....................... Albert Lea, Minn. Margaret Aleda Shiels........................ Kerkhoven, Minn. Mabel Amanda Sjolander......................... Dawson, Minn. Paul Milton Skiff. . . . . . . . . . . . . . . . . . . . . . . Hopkins, Minn. Paul Bryan Smith................................... Winnebago, Minn. Spencer Horace Smith............................ Wayzata, Minn. John Wesley Stokes............................ St. Paul, Minn.

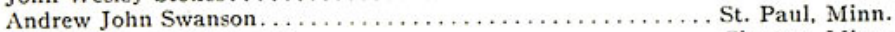

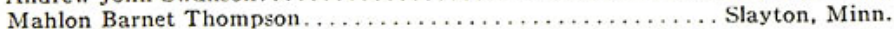
Florence Carine Thune........................ Redwood Falls, Minn.

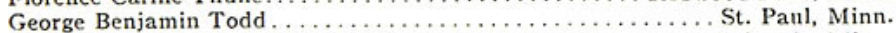
Archie William Troelstrup...................... Belgrade, Minn. Ruth Dorothy Whittaker....................... St. Paul, Minn.

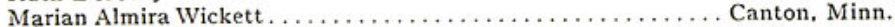
William Alexander Williams..................... Owatonna, Minn. Helen Elizabeth Wilson. ........................ Underwood, Minn. Clara Louise Wurdell . . . . . . . . . . . . . . . . . . . . . . . St. Paul, Minn.

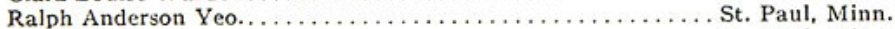

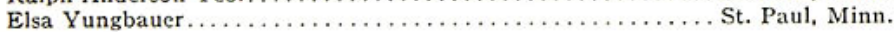

\section{Sophomore Class}

Maximino Fonbuena Abasolo . . . . . . . . . . . . . . Philippine Islands

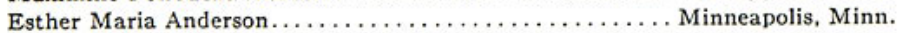

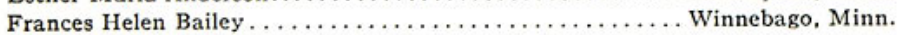
Ruth Louise Schoolcraft Bailey.................... Paul, Minn.

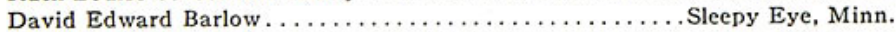
Howard Clinton Beresford $\ldots \ldots \ldots \ldots \ldots \ldots \ldots \ldots \ldots \ldots \ldots \ldots \ldots \ldots \ldots \ldots$ Vinton, Iowa Minnesota May Bocheck.....................Willow River, Minn. Reuben Oscar Boehlke...................... Buffalo Lake, Minn.

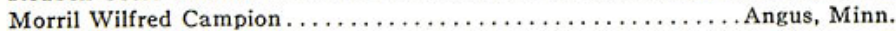

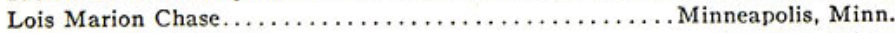

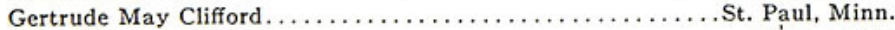

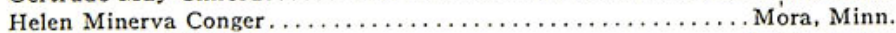

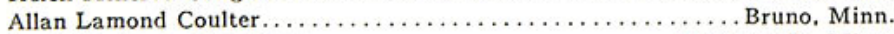
Janet Gertrude Donaldson........................... 
John Clifford Elsen

Glenwood, Minn.

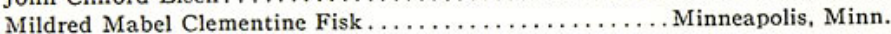

Raymond Garland Fletcher......................... Paul, Minn.

Marjorie Agnes Forbes. .......................... St. Paul, Minn.

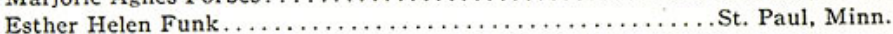

Irene Elizabeth Glendenning . . . . . . . . . . . .

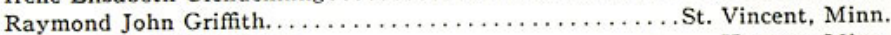

Margaret Ruth Gunderson. . . . . . . . . . . . . . . . . . .

Veina Katherine Gutzler......................... Paul, Minn.

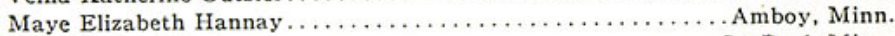

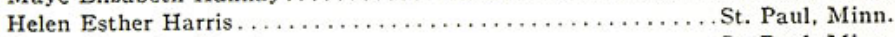

Henry Harpster Haupt. . . . . . . . . . . . . . . . . . . Paul, Minn.

George Ervin Hawley .......................... City, S. D.

Frances Amanda Hazzard . . . . . . . . . . . . . . . . . . . . . . .

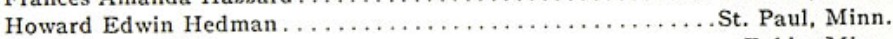

Lester August Helweg. . . . . . . . . . . . . . . . . . . . Fulda, Minn.

Eugene Lee Hibbard . . . . . . . . . . . . . . . . . . . Crookston, Minn.

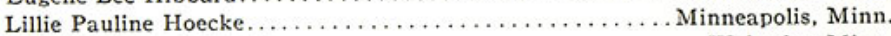

Leonard Loren Hubbell . . . . . . . . . . . . . . . . W Wabasha, Minn.

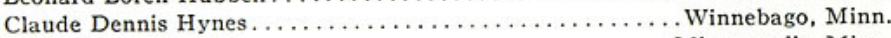

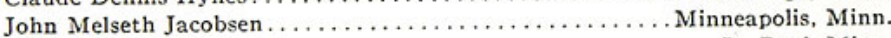

Hazel Ada Elizabeth Johanson. ...................... Paul, Minn.

Alice Johnson . . . . . . . . . . . . . . . . . . . . . . . . . . . .

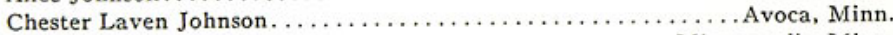

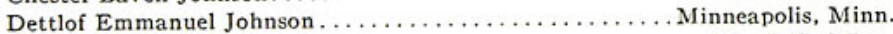

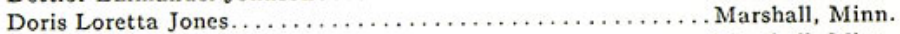

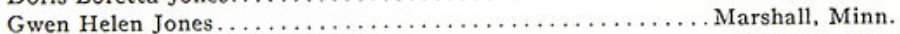

Helen Frances Katner . . . . . . . . . . . . . . . . . . . . . . .

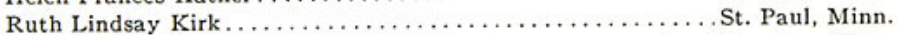

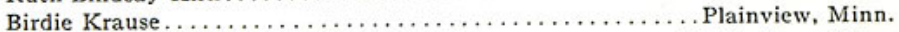

Donald Robert Latimer...................... White Bear, Minn.

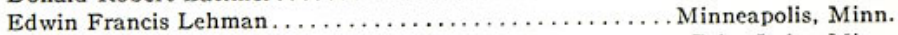

Lester Burton LeVesconte....................... Prior Lake, Minn.

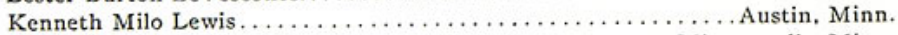

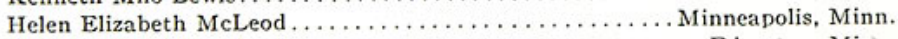

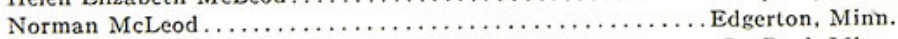

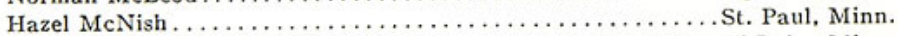

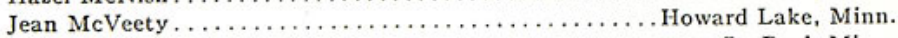

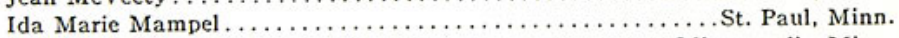

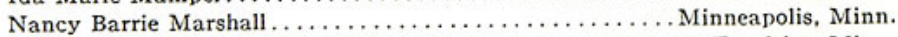

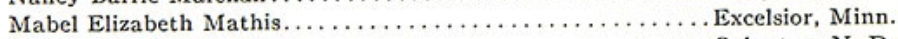

Wilma Beatrice Maulsby . . . . . . . . . . . .

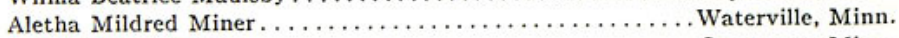

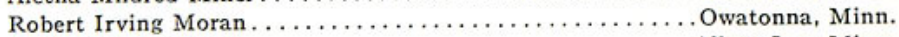

Carrie Laetitia Mott. . . . . . . . . . . . . . . . . . . Albert Lea, Minn.

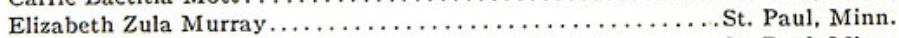

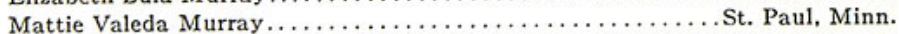

Arthur Henry Nelson . . . . . . . . . . . . .

Lucile Isadore Nelson . . . . . . . . . . . . . . . . . . . . Brooten, Minn.

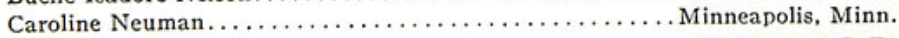

Stella Dorothy Nicol........................... 
Viroqua Carol Nodolf

Minneapolis, Minn.

Esther Lillian Nyberg. St. Paul, Minn.

Carroll Lloyd Olson. .

St. Paul, Minn.

Charles Edward Olson.

Minneapolis, Minn.

Mrs. Jennie Otis St. Paul, Minn.

William Theodore Paden Mankato, Minn.

Frank Forest Paskewitz. Philbrook, Minn.

Beatrice Isadore Pearson . Canby, Minn. Aneita Ruth Pennell. West Concord, Minn. Mabel Pauline Peterson....................................

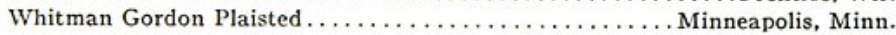

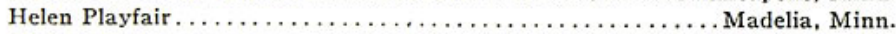

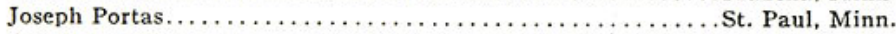
George Harland Purves . . . . . . . . . . . . . . . . . . . . . . . .

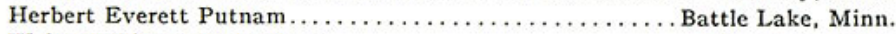

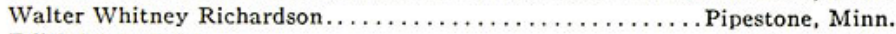

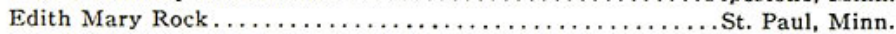

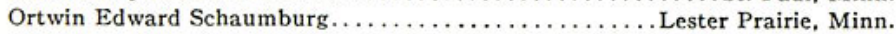

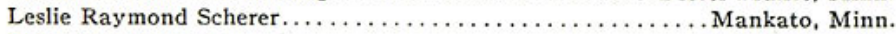

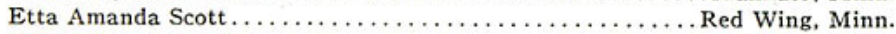
Helen Margaret Sellie............................. Sueur, Minn. Benjamin Henry Skerik ..................... Silver Lake, Minn. Arthur Clifton Skjold . . . . . . . . . . . . . . . . . .

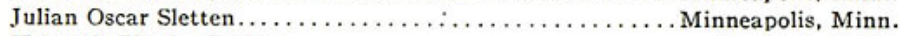

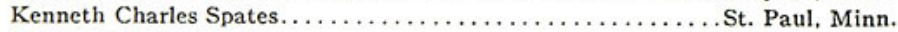

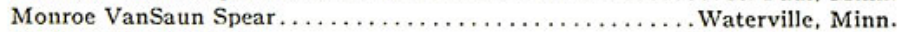
Marjorie Louise Strom . . . . . . . . . . . . .

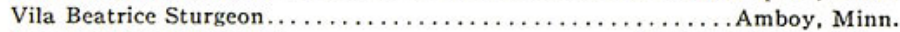
Leverne Henry Tanglen.................... Parker's Prairie, Minn. Thomas Fenwick Taylor....................... Fergus Falls, Minn.

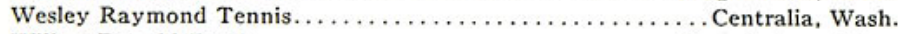
Wilbur Donald Tesch...................... Farmington, Minn.

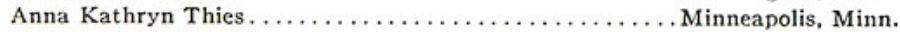

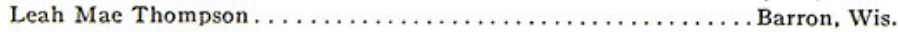

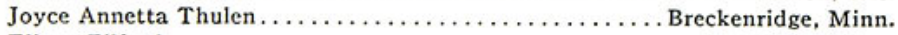

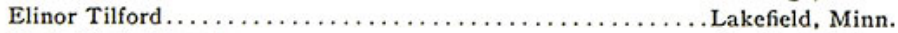

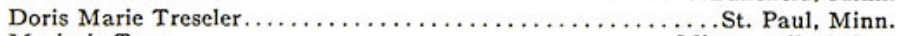

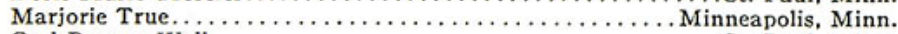

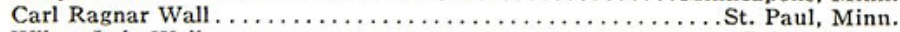
Wilma Lola Wallace..............................

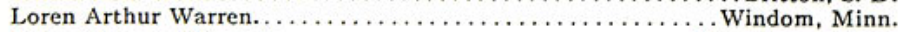
Robert Brooks Wasgatt. ....................... Winnebago, Minn.

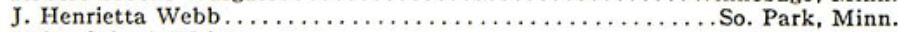

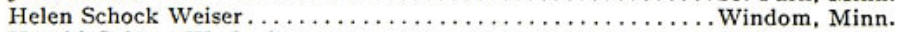
Harold Calvert Wetherby $\ldots \ldots \ldots \ldots \ldots \ldots \ldots \ldots \ldots \ldots \ldots \ldots \ldots \ldots \ldots$ Willmar, Minn. Lester Oliver Wilcox.......................... Elva Mavis Williams........................... James Smith Williams................................

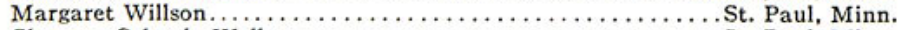

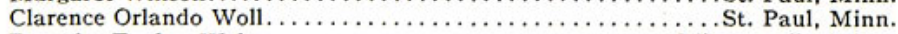
Dorothy Evelyn Wolter.........................

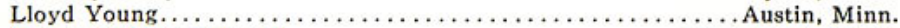
Victor Waldorf Ziebarth.......................... 


\section{Freshmen Class}

Marvin Wilford Adler.

Marshall, Minn.

Vida Ruth Alexander.

St. Paul, Minn.

Earl Fenton Altnow. ..................... Pelican Rapids, Minn.

Charlotte Mae Anderson . . . . . . . . . . . . . . . . . . Austin, Minn.

George Raymond Anderson. . . . . . . . . . . . . . . . . .

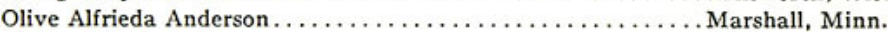

Walter Edwin Anderson . . . . . . . . . . . . . . . . . . Guckeen, Minn.

Naomi Emma Armitage . . . . . . . . . . . . . . . . . Minneapolis, Minn.

Margaret Lucile Arnold . . . . . . . . . . . . . . . . . . . Vesta, Minn.

George Emory Auld . . . . . . . . . . . . . . . . . . . . . . Vinton, Iowa

Ruth Adeline Bach................................. Paul, Minn.

Ralph Weibert Barnes............................ Paul, Minn.

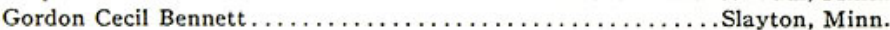

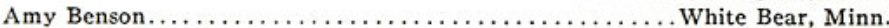

Adeline Luella Blum . . . . . . . . . . . . . . . . . . . . . Princeton, Minn.

Donald Reno Bosley . . . . . . . . . . . . . . . . . . . . . . .

Ada Harriet Bottge............................. Correll, Minn.

Gwendolyn Ava Bowen. . . . . . . . . . . . .

Mrs. Alice Hart Boyden........................ Pt. Paul, Minn.

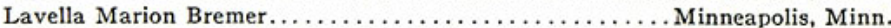

Marguerite Gladys Buck ....................Waterville, Minn.

Charles Cornelius Burges............................ Claty, Minn.

Maurice Edwin Buzzell ...................... Chatfield, Minn.

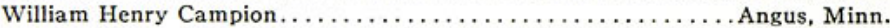

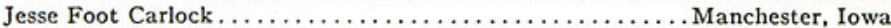

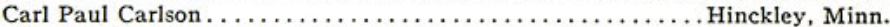

Monty Charlsen ................................

Warren William Chase.................................. Minn.

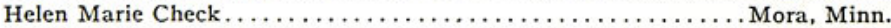

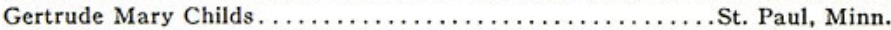

George Herbert Childs......................... Paul, Minn.

Jeanne Marion Chisholm....................... White Bear, Minn.

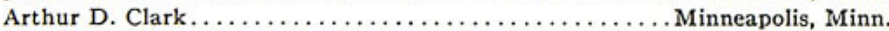

Theodore Kenneth Coles..................... Farmington, Minn.

Frances Laura Conner. . . . . . . . . . . . . . . . . . . . .

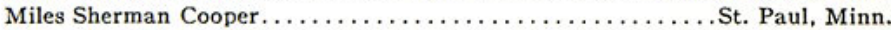

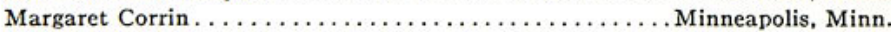

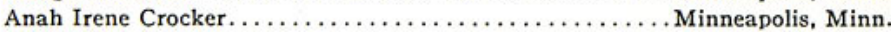

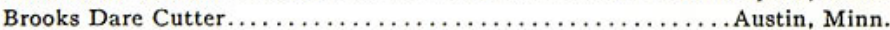

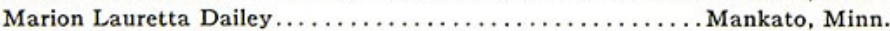

Harriet Lucille Danielson.......................... Minn.

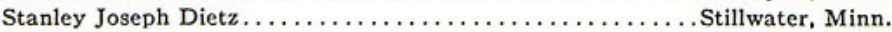

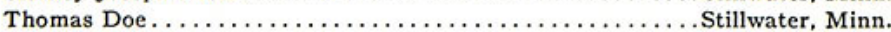

Florence Dunn $\ldots \ldots \ldots \ldots \ldots \ldots \ldots \ldots \ldots \ldots \ldots \ldots \ldots \ldots \ldots \ldots \ldots \ldots \ldots \ldots$ St. Paul, Minn.

Francis Eckardt............................... Se Sueur, Minn.

Joseph Willard Edwards............................ Paul, Minn.

Myrtle May Ehnert...................... New York Mills, Minn.

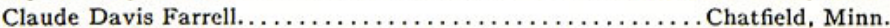

Edwin Frank Ferris . . . . . . . . . . . . . . 
Dorothy June Field. Yankton, S. D.

Dorothy Evaleen Fisher. Brainerd, Minn.

Gerard Vincent Flaherty. Elk River, Minn.

Anna Goebel. Belle Plaine, Minn.

Ward Harrison Goodwin St. Paul, Minn.

Donald James Graham . Carroll, Iowa

Donald William Graham St. Paul, Minn. Vivian Josephine Grant. Minneapolis, Minn.

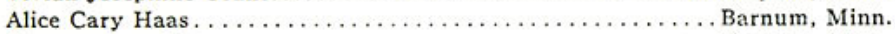

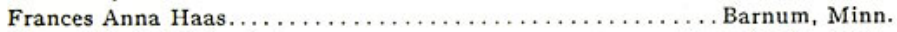
Eileen Schofield Harrington.................... Grey Eagle, Minn.

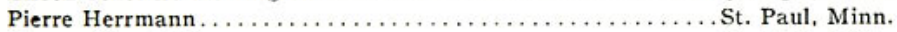
George Francis Hoppe . . . . . . . . . . . . . . . . . . . . Paul, Minn. Roy Hotchkiss. Fairmont, Minn. Margaret Hughes.

Minneapolis, Minn. Jeanne Victor Hugo. Duluth, Minn. Maurice Alfred Hunt Hinckley, Minn. Alice Ionia James. . St. Paul, Minn.

Violet Anna Maude Jensen. Pine City, Minn.

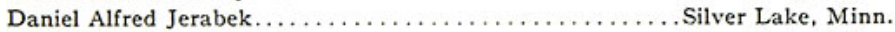
Theophil Edward Jerabek . . . . . . . . . . . . . . . . . . Silver Lake, Minn. Jesse Beaumont Jestus . . . . . . . . . . . . . . . . . . . . . . . . . . . . . Edwin Albert Johnson. . . . . . . . . . . . . . . Redwood Falls, Minn.

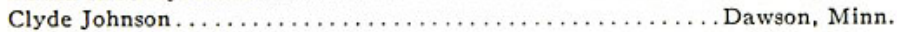

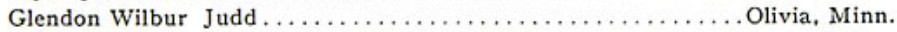

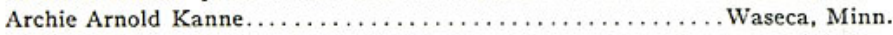

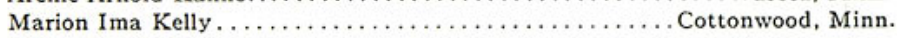
Gladys Faye Kingsland . . . . . . . . . . . . . . . . . . . . . .

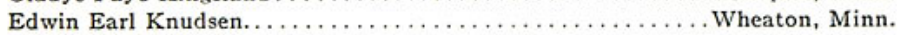

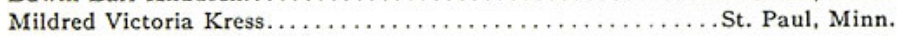
Marian Elizabeth Larsen.......................... Paul, Minn. Arthur Charles Larson. . . . . . . . . . . . . . . . . . . . . Paul, Minn. Leona Virginia Lehrer...................... So. Stillwater, Minn.

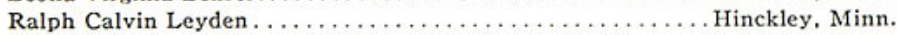
Clifton Smith Lines........................ Brown's Valley. Minn.

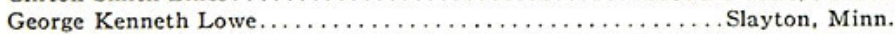
Mary Francis Lyon....................... Parker's Prairie, Minn.

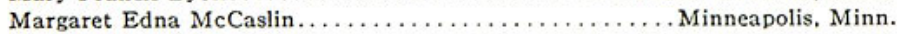

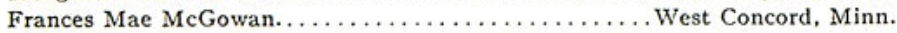
Herbert Arthur McQuillan.......................... Paul, Minn.

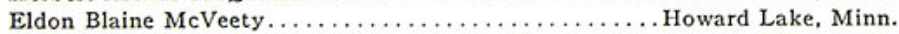

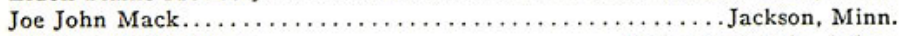
Elsie Lucile Malchow..................... White Bear Lake, Minn.

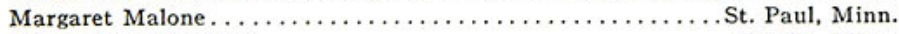

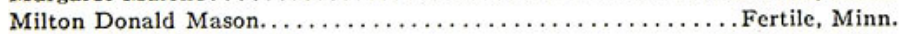
Reuben Benjamin Meckel.....................Wabasso, Minn.

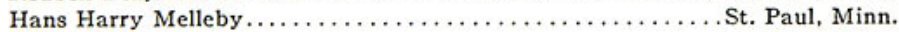

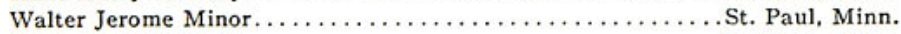

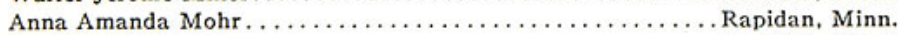

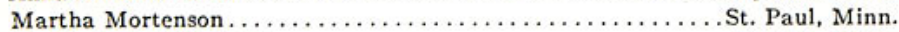

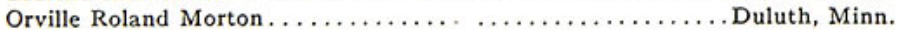


Florence Ione Mosher. Faribault, Minn. Dorothy Elizabeth Mourer. . . . . . . . . . . . . . . . Pt. Paul Park, Minn. Grace Evelyn Nehls ........................... Tracy, Minn. Ferdinand Elsworth Nelson.................... Fergus Falls, Minn.

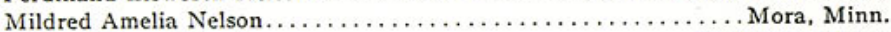

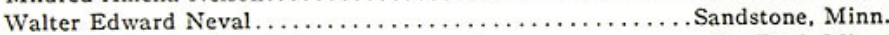
Evelyn Catherine Odendahl......................... Paul, Minn.

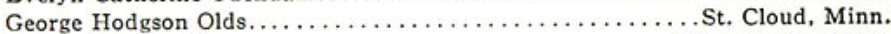
Mildred Sophie Olsen . . . . . . . . . . . . . . . . . . Minneapolis, Minn.

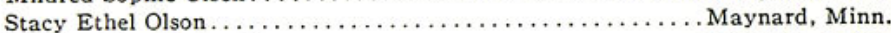

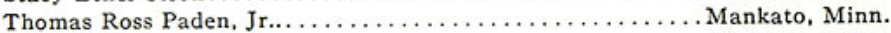
Isabel Wilhelmina Pederson. . . . . . . . . . . . . . . . . . . . . Elma Lydia Peltola ........................... Ironton, Minn.

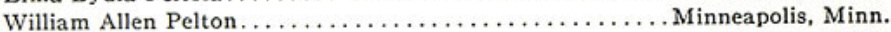

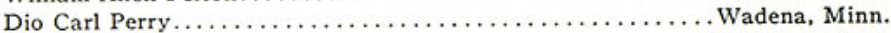
Dale John Peterson.............................. Donnelly, Minn. Laura Helen Peterson..................... White Bear Lake, Minn.

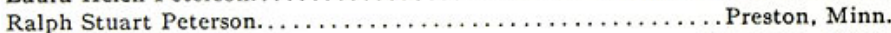

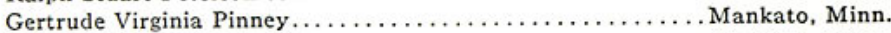

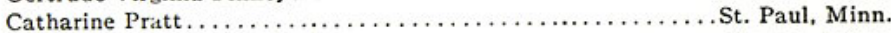

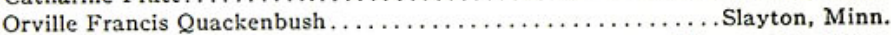

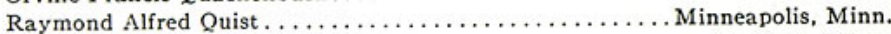
Julius Clifford Reed ........................... Paul, Minn. Louis Aron Reinmuth ....................... Howard Lake, Minn.

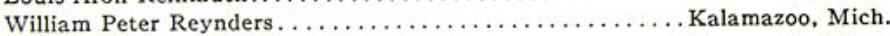

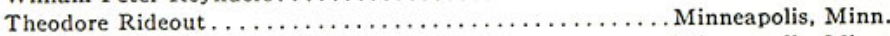

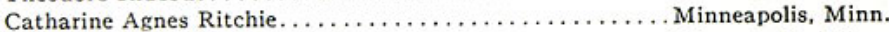

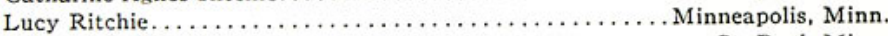

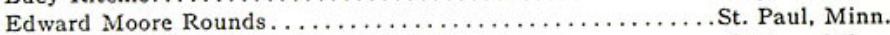

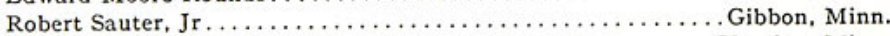

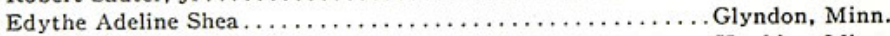

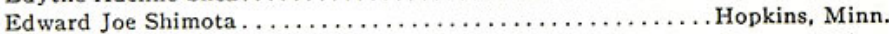

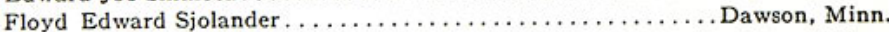
Malcolm Lorrain Smiley...................... rookston, Minn. Norma Hope Springmyer . . . . . . . . . . . . . . . . Canton, Minn. Charles Edwards Stark. . . . . . . . . . . . . . . . . . Buffalo, Minn.

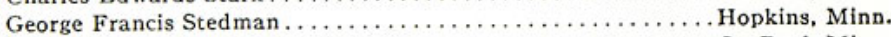
John Giongas Glasgow Stephens.................... Paul, Minn. Muriel Evelyn Stolt ............................ Paul, Minn.

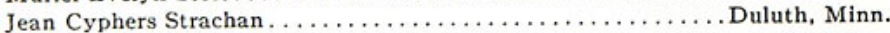

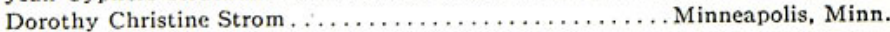

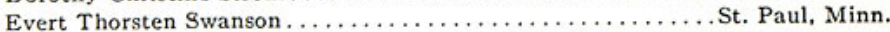
Gertrude Marie Swenson......................... St. Paul, Minn.

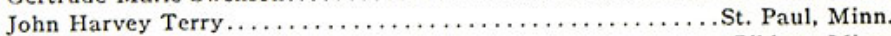
Julia Tester . . . . . . . . . . . . . . . . . . . . . . . . . . . . . Verne Gertrude Thomas.......................... Paul, Minn.

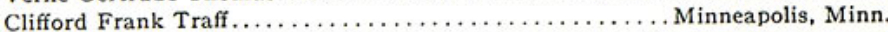

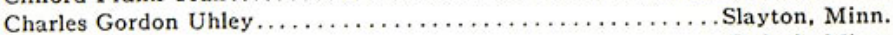

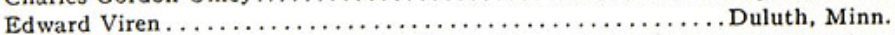

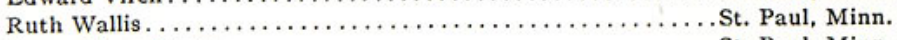

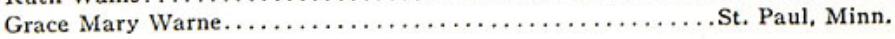


Lila Harriet Watkins. Sioux Falls, S. D.

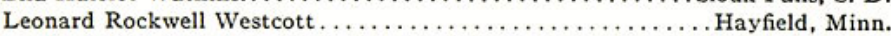
Esther Josephine Wiek . . . . . . . . . . . . . . . . . Minneapolis, Minn.

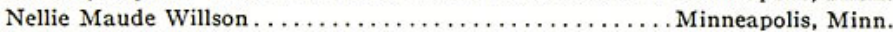
Lita Evangeline Wilson. .......................... Paul, Minn. Elmer Norris Woll.............................. St. Paul, Minn. Barbara Lillian Young. . . . . . . . . . . . . . . . . . . . . . Paul,

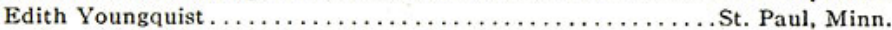

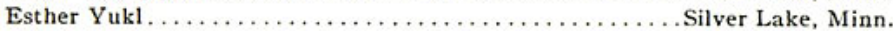

\section{Conservatory of Music}

Gladys Aalbue St. Paul, Minn. Jessarose Alexander............................ Paul, Minn. Muriel Alexander............................... Paul, Minn.

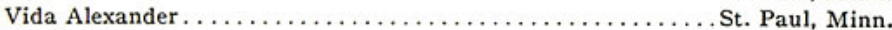
Charlotte Anderson . . . . . . . . . . . . . . . . . . . . . . .

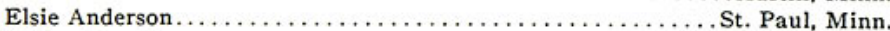
Esther Appelbaum............................. Paul, Minn.

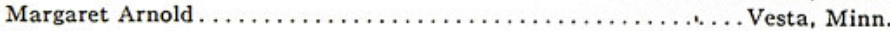
Mrs. K. Arouni . . . . . . . . . . . . .

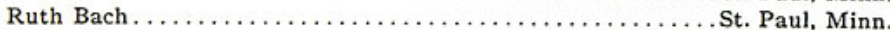

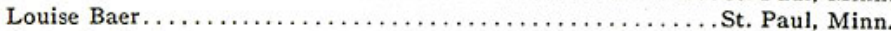

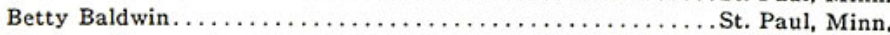
Florence Bauermeister . . . . . . . . . . . . . . . . . . . . . . .

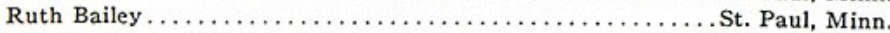

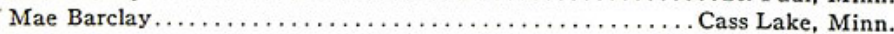

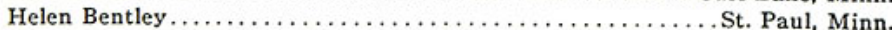
Minnesota Bocheck. .......................Willow River, Minn.

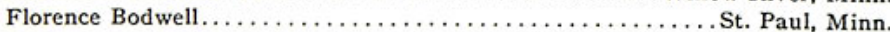

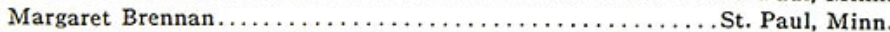

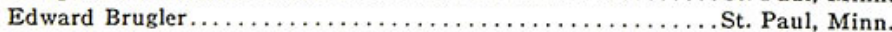

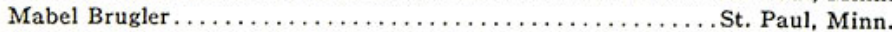

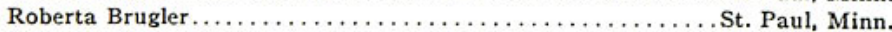

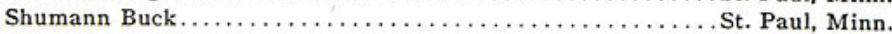

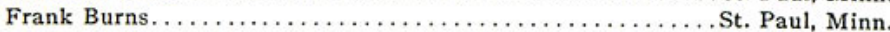

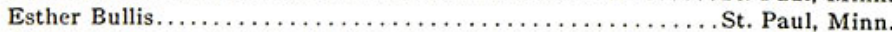

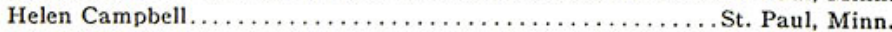

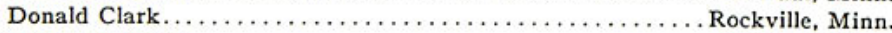

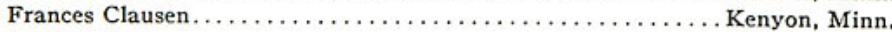

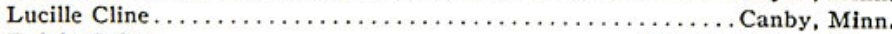

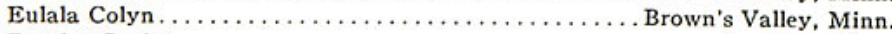

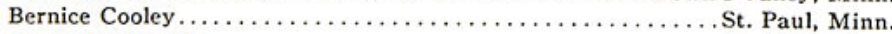

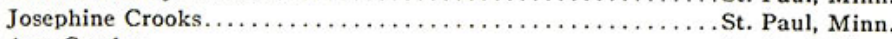

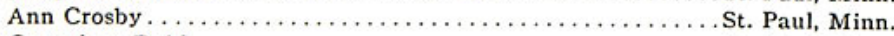

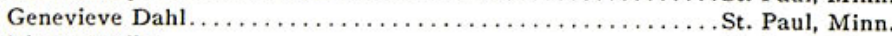

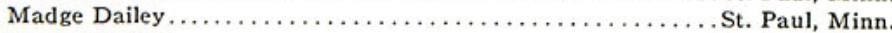

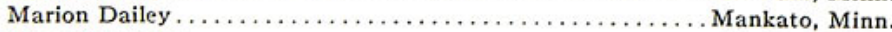

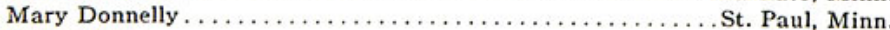

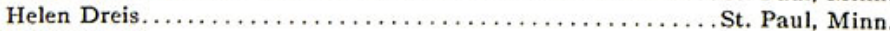

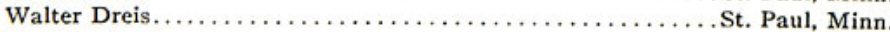

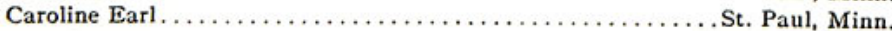


Dorothy Edwards.

St. Paul, Minn.

James Ekholm.

St. Paul, Minn.

Rosella Elmer.

St. Paul, Minn.

Miriam Emhoff. York, Neb.

Audrey Engemoen.

St. Paul, Minn.

Carl Engemoen .

St. Paul, Minn.

Dorothy Engemoen.

St. Paul, Minn.

Reinhold Ericson.

Minneapolis, Minn.

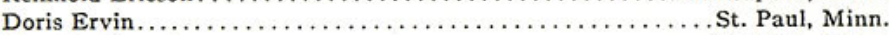

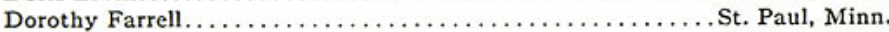

Elizabeth Farrell. . . . . . . . . . . . . . . . . . . . . . . . Paul, Minn.

Virginia Farrell . . . . . . . . . . . . . . . . . . . . . . . . . Paul, Minn.

Dorothy Fisher $\ldots \ldots \ldots \ldots \ldots \ldots \ldots \ldots \ldots \ldots \ldots \ldots \ldots \ldots \ldots \ldots$ Brainerd, Minn.

Alice Fitch $\ldots \ldots \ldots \ldots \ldots \ldots \ldots \ldots \ldots \ldots \ldots \ldots \ldots \ldots \ldots \ldots \ldots \ldots \ldots \ldots \ldots$ St. Paul, Minn.

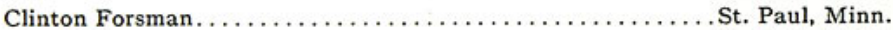

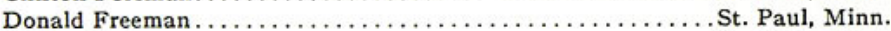

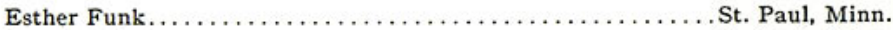

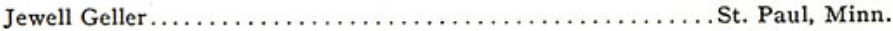

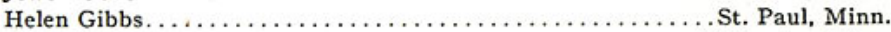

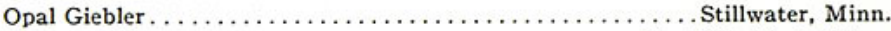

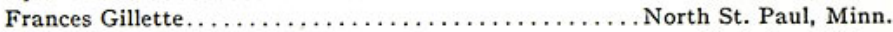

Elsie Glaesmer. . . . . . . . . . . . . . . . . . . . . . . . . .

Florence Gleckman. . . . . . . . . . . . . . . . . . . . . . . . . .

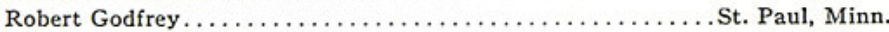

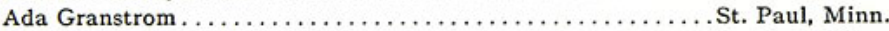

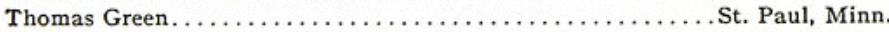

Mrs. Handsacker $\ldots \ldots \ldots \ldots \ldots \ldots \ldots \ldots \ldots \ldots \ldots \ldots \ldots \ldots \ldots \ldots \ldots \ldots \ldots \ldots$ St. Paul, Minn.

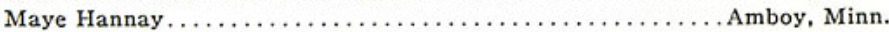

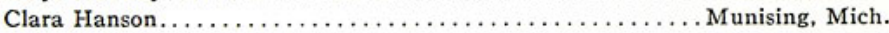

George Hawley . . . . . . . . . . . . . . . . .

Dorothy Haxton . . . . . . . . . . . . . . . . . . . . . . . . . .

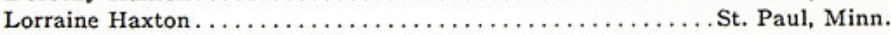

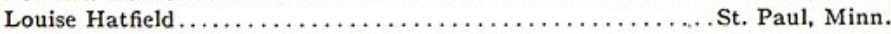

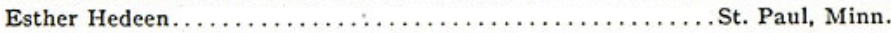

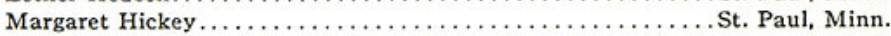

Louise Hoffman. . . . . . . . . . . . . . . . . . . . . . . . . .

Charline Hohn . . . . . . . . . . . . . . . . . . . . . . . . .

Fred Holmquist . . . . . . . . . . . . . . . . . . . . . . Forest Lake,

Eloise Holterhoff.$\ldots \ldots \ldots \ldots \ldots \ldots \ldots \ldots \ldots \ldots \ldots \ldots \ldots \ldots \ldots \ldots \ldots \ldots \ldots \ldots$ St. Paul, Minn.

Mrs. G. W. Hopkins...................... Paul, Minn.

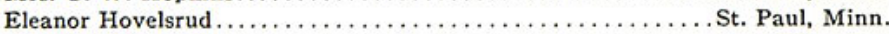

Virginia Hultgren. . . . . . . . . . . . . . . . . . . . . . . . . . .

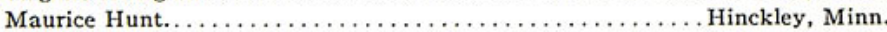

Marjorie Hyslop . . . . . . . . . . . . . . . . . . . . . . . .

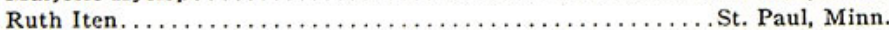

Victor Jacobson . . . . . . . . . . . . . . . . . . . . . . . . . .

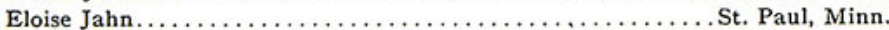

Marjorie Jelinek............................. Paul, Minn.

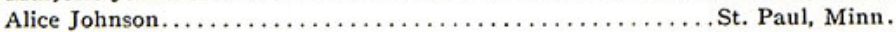

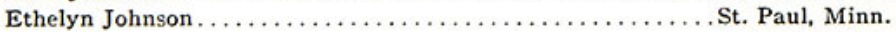

E. B. Johnson $\ldots \ldots \ldots \ldots \ldots \ldots \ldots \ldots \ldots \ldots \ldots \ldots \ldots \ldots \ldots \ldots \ldots \ldots \ldots$ St. Paul, Minn. 
Mildred Johnson........................... Pt. Paul, Minn.

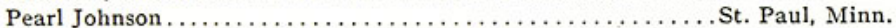

Myretta Johnston. . . . . . . . . . . . . . . . . . . . Forest River, N.

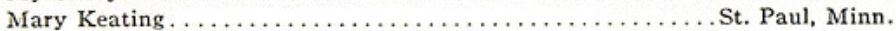

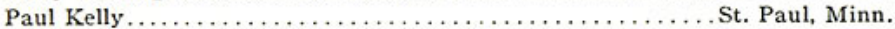

Katherine Kennedy ........................... Paul, Minn.

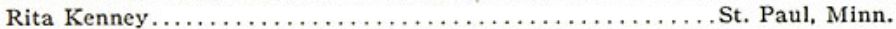

Winnifred Kenney............................. Paul, Minn.

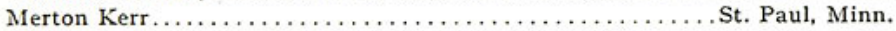

Catherine King . . . . . . . . . . . . .

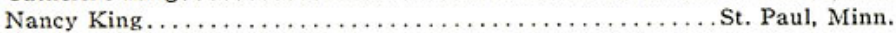

Annetta Kjolstad ............................ Paul, Minn.

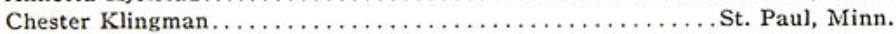

Goodwin Kolstad.................................. Paul, Minn.

Harold Kraushaar............................. Paul, Minn.

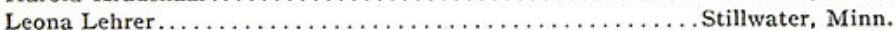

Marie Lemieux. ... . . . . . . . . . . . . . . . . . . . . . . . . Paul,

John Lilley. . . . . . . . . . . . . . . . . . . . . . . . . . Paul, Minn.

John Lindstrom........................... Paul, Minn.

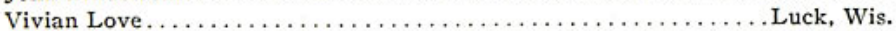

Melville McCluskey ............................ Paul, Minn.

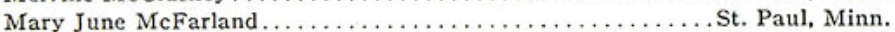

Frances McGowan ...........................West Concord, Minn.

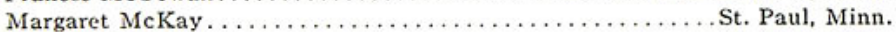

Neil McKenna.................................. Paul, Minn.

Norman McLeod .............................. Edgerton, Minn.

Norman McVeigh............................. Paul, Minn.

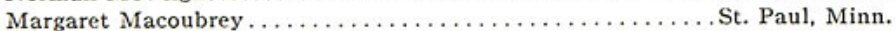

Gloria Marles................................. St. Paul, Minn.

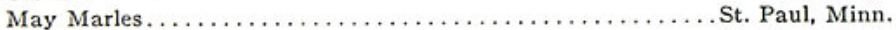

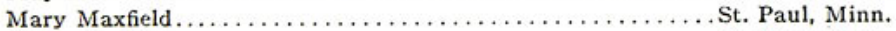

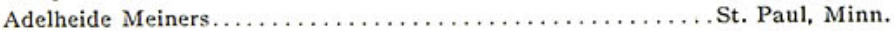

Marian Mellgren ........................... Paul, Minn.

Kurt Meese................................. Pt. Paul, Minn.

Gordon Mikkelson........................... Paul, Minn.

Leah Minor. . . . . . . . . . . . . . . . . . . . . . . . . . . . .

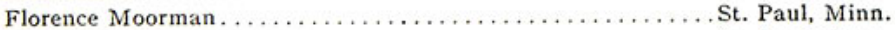

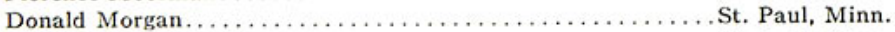

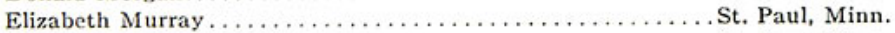

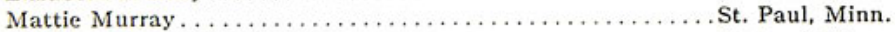

Permilla Murray ........................... Paul, Minn.

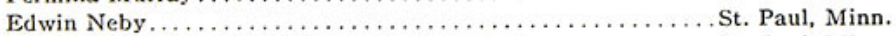

Dorothy Neibel .......................... Paul, Minn.

Margaret Neibel . . . . . . . . . . . . . . . . . . . . . St. Paul, Minn.

Lucile Nelson. . . . . . . . . . . . . . . . . . . . . . . Brooten, Minn.

Holly Ness . . . . . . . . . . . . . . . . . . . . . . . . . . . .

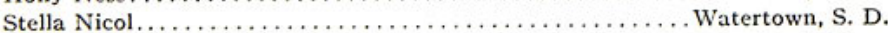

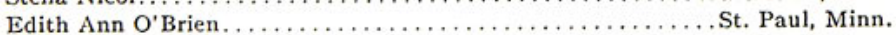

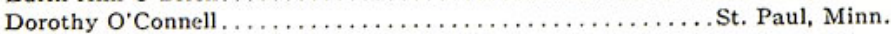

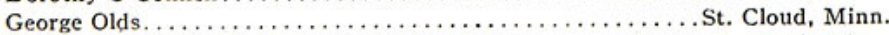

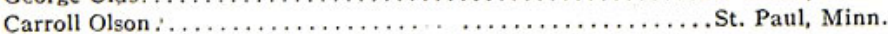


Maurice O'Minsky .

St. Paul, Minn.

Charlotte Ossery

St. Paul, Minn.

Zelda Ossery

St. Paul, Minn.

Gwen Owen.

Mandan, N. D.

Aneita Pennell

West Concord, Minn.

Richard Rand .

St. Paul, Minn.

John Rau.

St. Paul, Minn.

Florence Ravenscroft

St. Paul, Minn.

Sheila Ray .

St. Paul, Minn.

Alfred Reidel.

St. Paul, Minn.

Arman Reinke

St. Paul, Minn.

Amalia Renz .

St. Paul, Minn.

Gertrude Renz

St. Paul, Minn.

Helen Renz...

St. Paul, Minn.

Edith Repke.

St. Paul, Minn.

Geraldine Rink

St. Paul, Minn.

Eleanor Ritt . .

St. Paul, Minn.

Warren Rivers. .

St. Paul, Minn.

Frances Robinson

St. Paul, Minn.

Dollie Rosenberg.

St. Paul, Minn.

Laurice Russell.

St. Paul, Minn.

Robert Sands.

St. Paul, Minn.

Dorothy Samuelson.

St. Paul, Minn.

Mildred Schuldt.

St. Paul, Minn.

Muriel Schwartz

St. Paul, Minn.

Adeline Shea

Glendon, Minn.

Merrill Sherman

St. Paul, Minn.

Siff ra Simon.

St. Paul, Minn.

Paul Smith

Winnebago, Minn.

Lorraine Sobelman.

St. Paul, Minn.

Mr. Starkvedt

St. Paul, Minn.

Margaret Starvick.

St. Paul, Minn.

John Wesley Stokes.

St. Paul, Minn.

Jean Strachan.

Duluth, Minn.

Dorothy Strom.

Minneapolis, Minn.

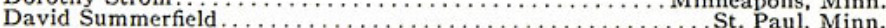

Dorothy Summerfield ....................

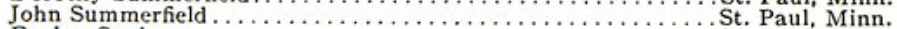

Evelyn Sunberg................................... Paul, Minn.

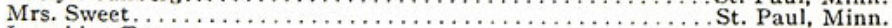

Josephine Tatum. . . . .

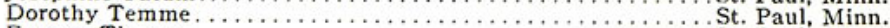

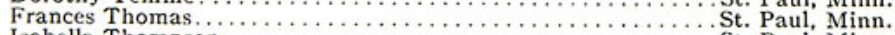

Isabella Thompson. ................................. Paul, Minn.

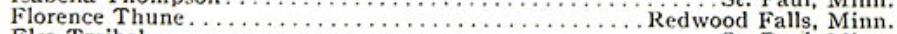

Elsa Treibel ......................................... Paul, Minn.

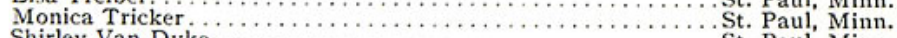

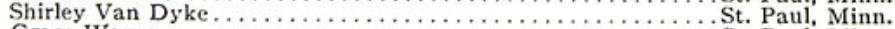

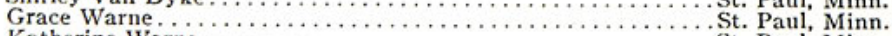

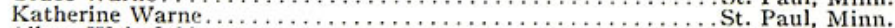

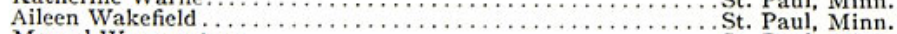

Marvel Wangensteen . . . . . . . . . . .

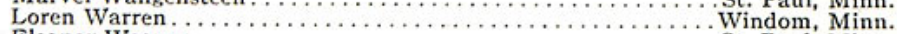

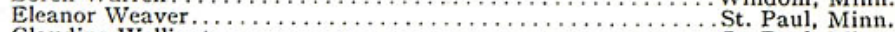

Claudine Wellington...................

Florence Wiebmer...........

Esther Wiek . . . . . . . . . . .

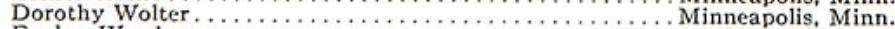

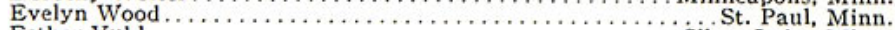

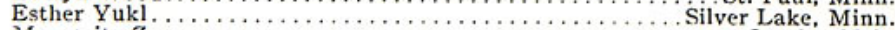

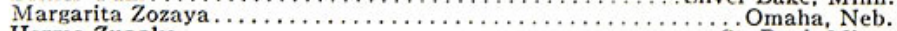

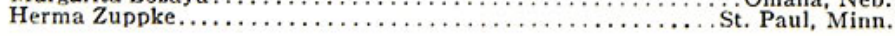




\section{Summary of Students}

College.................................. 464

Conservatory of Music....................... 205

Total.............................. 669

Counted twice............................. 57

Net total . . . . . . . . . . . . . . . . . . . 612 


\section{INDEX}

PAGE

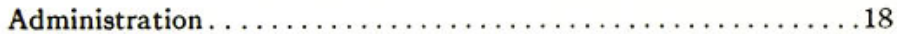

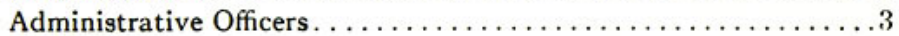

Admission. . . . . . . . . . . . . . . . . . . . . . . 32

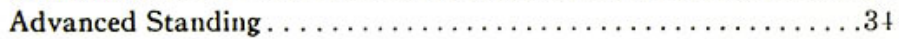

Advisers. . . . . . . . . . . . . . . . . . . . . . . . . 42

Alumni. ...................................

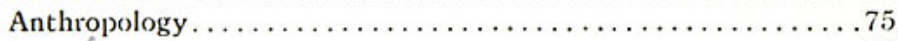

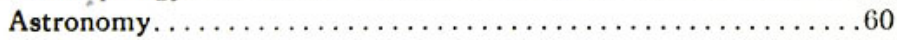

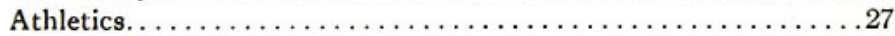

Bequest, Form of . . . . . . . . . . . . . . . . . . . .

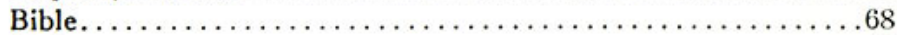

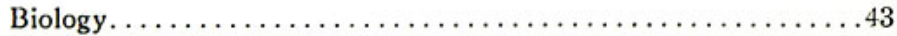

Buildings and Equipment...........................

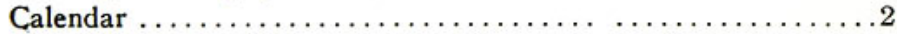

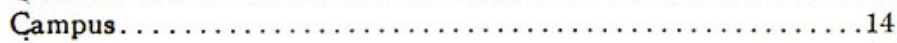

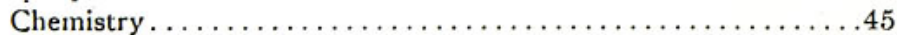

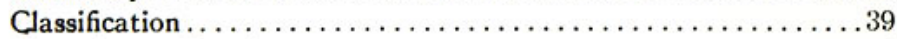

Committees, Faculty $\ldots \ldots \ldots \ldots \ldots \ldots \ldots \ldots \ldots \ldots \ldots \ldots$

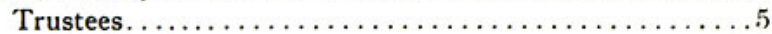

Conservatory of Music . . . . . . . . . . . . . . . . 79

Courses of Study ............................ 43,81

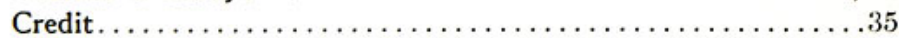

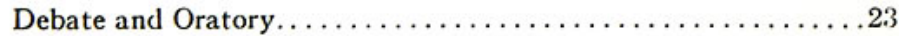

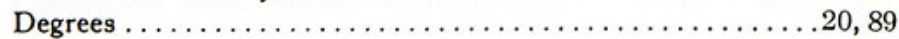

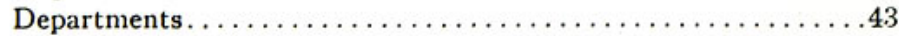

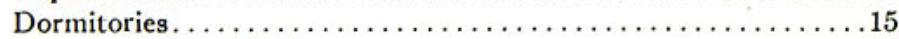

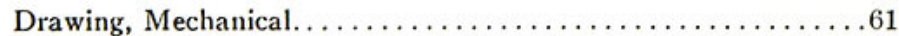

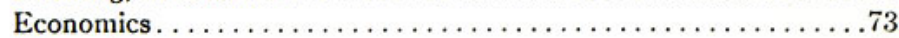

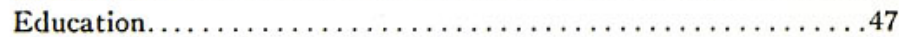

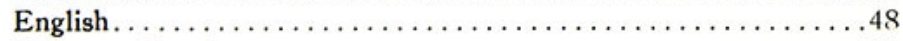

Entrance Requirements. . . . . . . . . . . . . . . . . . . 32

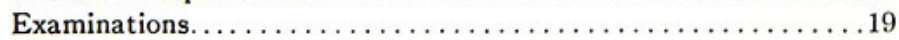

Expenses.............................. 88

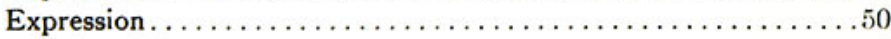

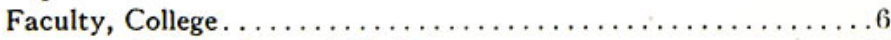

Conservatory of Music . . . . . . . . . . . . . . 80

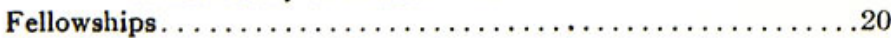

Forensics . . . . . . . . . . . . . . . . 
PAGE

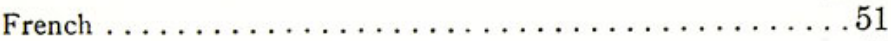

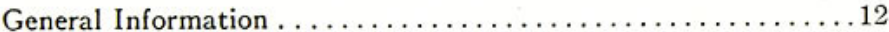

Geology . . . . . . . . . . . . . . . . . . . . . . . . . . . . . . . . . 52

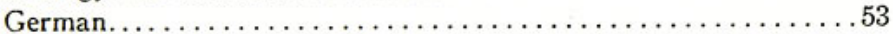

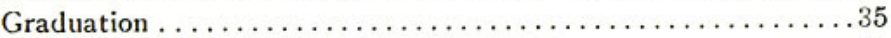

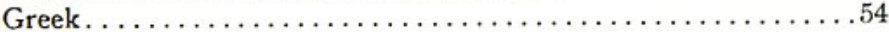

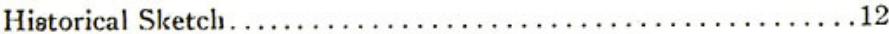

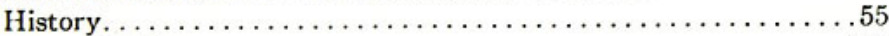

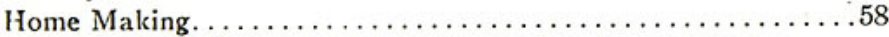

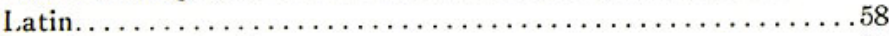

Law, Preparation for . . . . . . . . . . . . . . . . . . 40

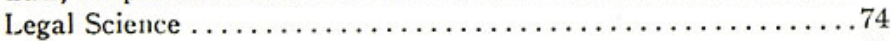

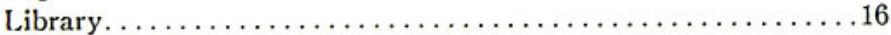

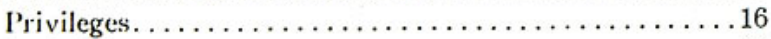

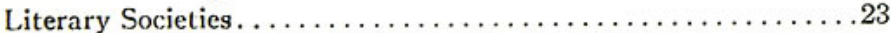

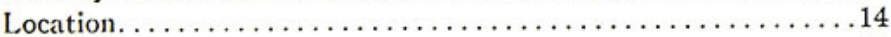

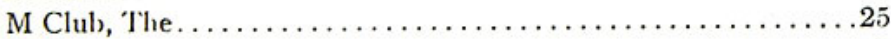

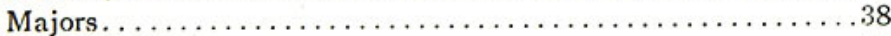

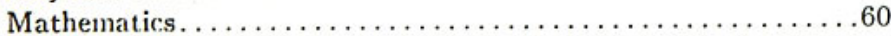

Medicine, Preparation for. . . . . . . . . . . . . . . . 40

Mental Sciences. . . . . . . . . . . . . . . . . . . . . . . . . .

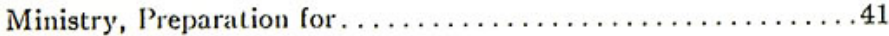

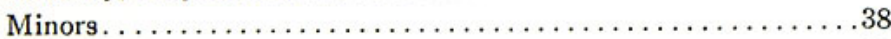

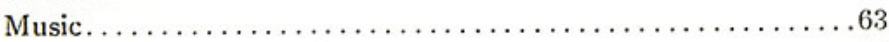

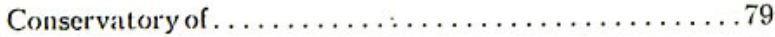

Philosophy. . . . . . . . . . . . . . . . . . . . . 61

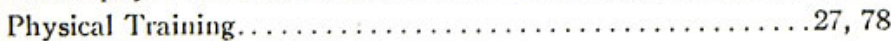

Physics. . . . . . . . . . . . . . . . . . . . . . . . . . . . . . . . . .

Pi Phi Epsilon Society. . . . . . . . . . . . . . . . . 25

Political Science. . . . . . . . . . . . . . . . . . . 44

Presidents. . . . . . . . . . . . . . . . . . . . . . . . 14

Prizes. . . . . . . . . . . . . . . . . . . . . . . . . . .

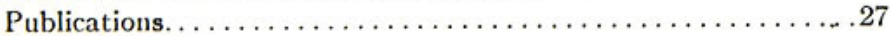

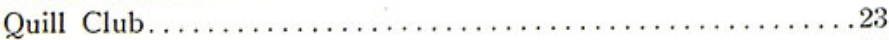

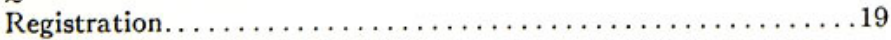

Religious Education . . . . . . . . . . . . . . . 68

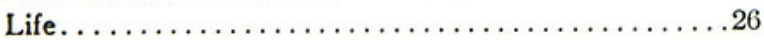

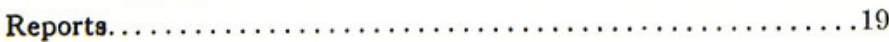


Requirements for Graduation . . . . . . . . . . . . . . . . 35

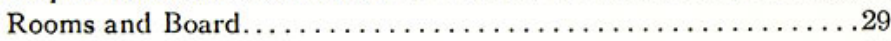

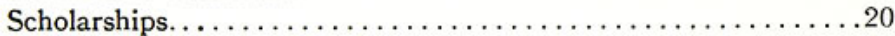

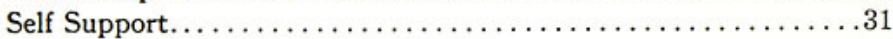

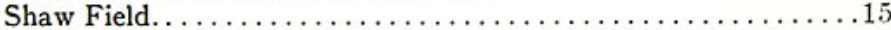

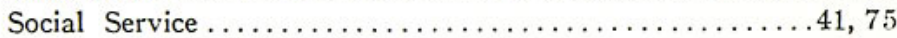

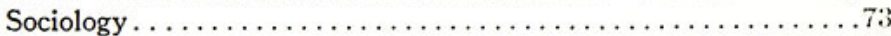

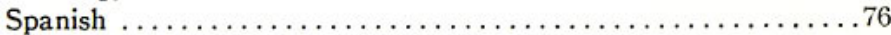

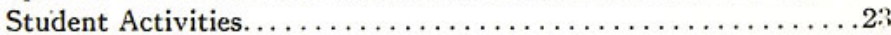

Students, Roll of ............................... 109

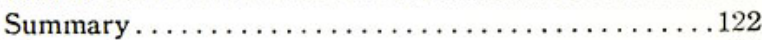

Teachers' Bureau. .............................

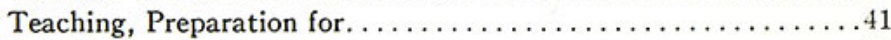

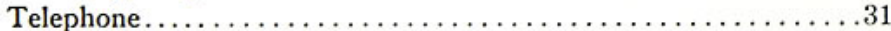

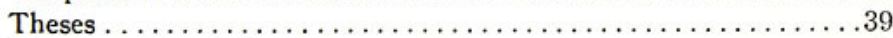

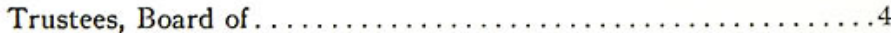

Committees........................

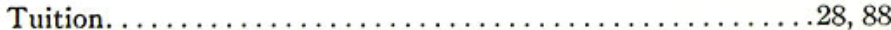

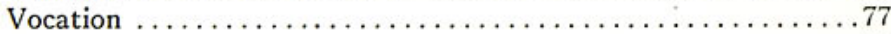

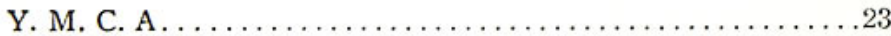

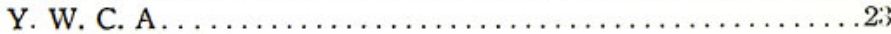



62

(2)

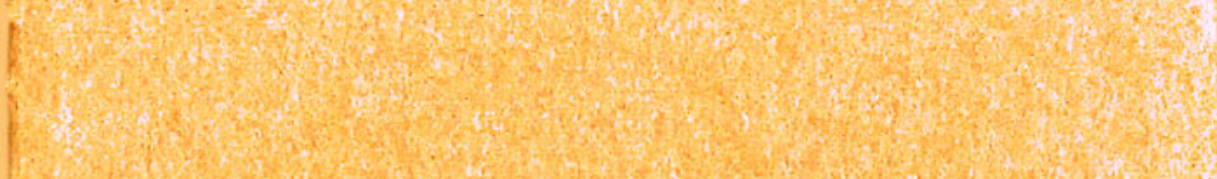

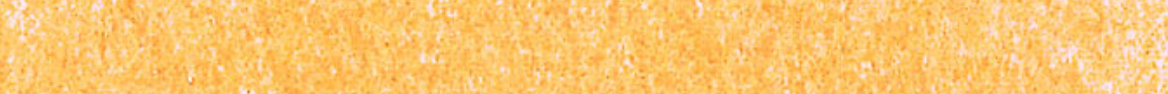

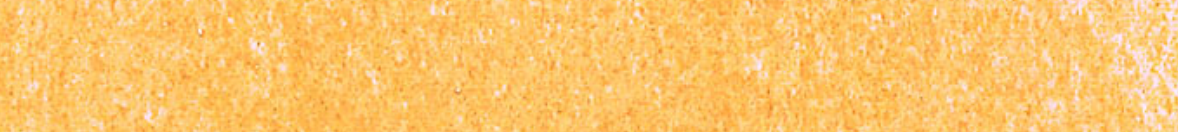


